\title{
Identification of cereal
} remains from

\section{archaeological sites \\ 2nd edition \\ 2006}

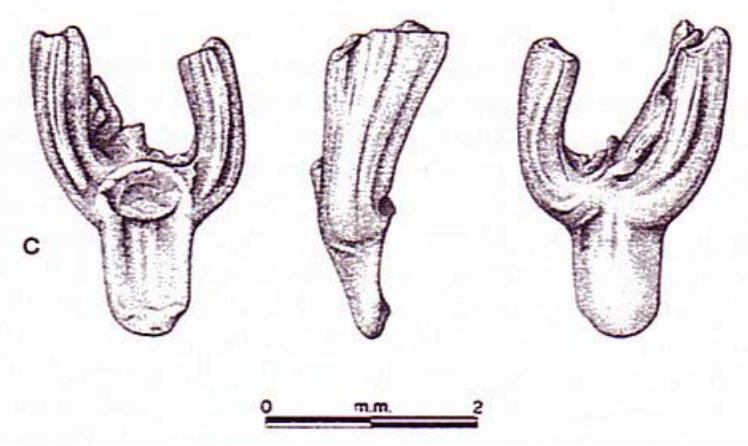

Spikelet fork of the "new glume wheat" (Jones et al. 2000)

\author{
Stefanie JACOMET \\ and collaborators \\ Archaeobotany Lab \\ IPAS, Basel University
}

English translation partly by James Greig 


\section{Fam. Poaceae /Gramineae (Grasses)}

\section{Systematics and Taxonomy}

All cereal species belong botanically (taxonomically) to the large family of the Gramineae (Poaceae). This is one of the largest Angiosperm families with >10 000 different species. In the following the systematics for some of the most imporant taxa is shown:

class: Monocotyledoneae

order: Poales

familiy: Poaceae (= Gramineae) (Süssgräser)

subfamily: Pooideae

Tribus: Triticeae

Subtribus: Triticinae

genera: Triticum (Weizen, wheat); Aegilops; Hordeum (Gerste; barley); Elymus; Hordelymus; Agropyron; Secale (Roggen, rye)

Note: Avena and the millets belong to other Tribus.

The identification of prehistoric cereal remains assumes understanding of different subject areas in botany. These are mainly morphology and anatomy, but also phylogeny and evolution (and today, also genetics). Since most of the cereal species are treated as domesticated plants, many different forms such as subspecies, varieties, and forms appear inside the genus and species (see table below). In domesticates the taxonomical category of variety is also called "sort" (lat. cultivar, abbreviated: cv.). This refers to a variety which evolved through breeding. Cultivar is the lowest taxonomic rank in the domesticated plants. Occasionally, cultivars are also called races: e.g. landraces evolved through genetic isolation, under local environmental conditions whereas „high-breed-races“ were breed by strong selection of humans. Anyhow: The morphological delimitation of cultivars is difficult, sometimes even impossible. It needs great experience and very detailed morphological knowledge.

The species and its taxonomic subdivision Schubert/Wagner 1988

\section{Wissenschaftliche \\ Bezeichnung \\ Mögliche Gliederung der Art und ihrer Sippen}

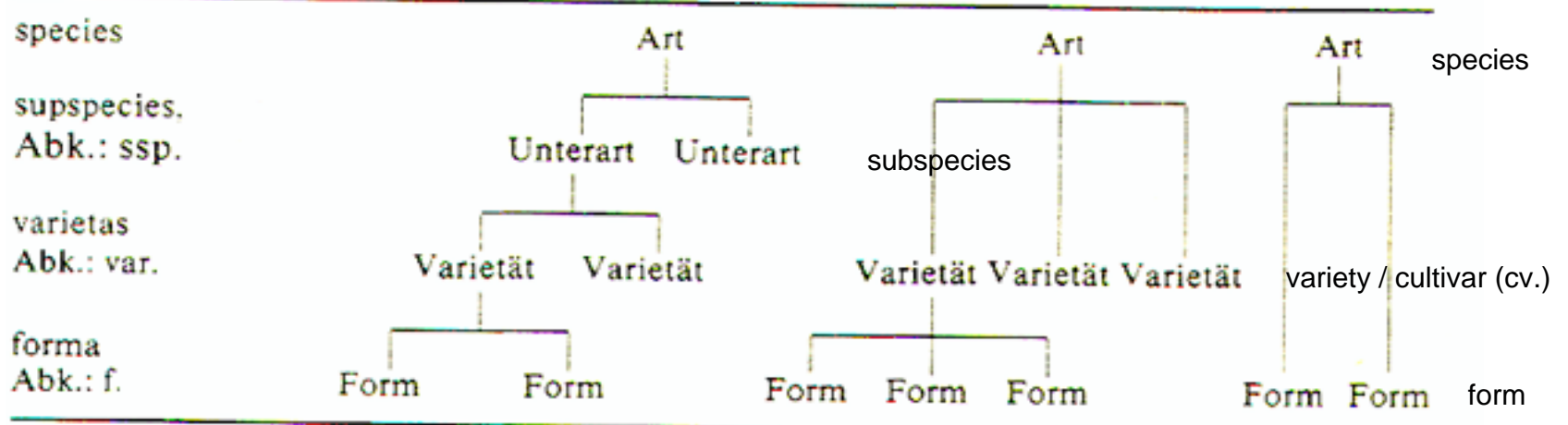




\section{Introduction, conditions for identification}

The starch- and protein-rich grains of the cereals represent the most important basic foodstuff from the time of the arrival of Neolithic culture. Cereals were cultivated from the earliest Neolithic in the Near East, and in Central Europe Cereal since around the 6th millenium BC. The study of their remains from archaeological excavations is therefore of very great importance. They play a great role in research into the origins of nutrition; additionally, they can offer useful information on the immigration routes but also social aspects of certain cultures (for the latter see e.g. Bogaard 2004).

The individual cereal species had a varying importance in the different epochs of the past. The oldest central European cereals are various wheat species (genus $\underline{\text { Triticum) }}$ ) and barley (genus $\underline{\text { Hordeum }}$ ). (Mostly) after the Neolithic, millet species, oats and rye arrived in central Europe.

In the following we try to give an overview of the present state of knowledge concerning cereal identification, including also at least some aspects of papers published on the topic since the first edition of our "Cereal Identification manual" (Jacomet 1987). In addition to information from the current literature, we included many of our own results which have arisen in our long-term work with archaeological and recent remains of domesticated plants.

All existing plant-identification books (Floras) are hardly useable for archaebotanical purposes, since plant parts which contain important diagnostic characters are either not or only fragmentarily preserved. One finds whole plants or at least whole inflorescences only in the rarest instances - in the case of the cereals mostly ears. In $>95 \%$ of cases we encounter cereals in the form of single grains, parts of the rachis, glumes, awns and finally straw (culm) fragments (see figures on the following pages). The remains are present mostly in a charred state, so that it is difficult to compare their dimensions with those of modern material. Uncharred cereal remains, mostly remains of rachis and glume bases, have their original size, but are mostly very fragmentary, often badly corroded or pressed (and therefore deformed). The identification of cereal remains always depends principally upon morphological criteria. Measurement data can be used additionally to assist identification. This last is also useful for the comparison of different sites under investigation. Occasionally, one must fall back on anatomical characters for identification. It is also important to record precisely the state of preservation of plant remains. Also, when cereal remains can often be identified on the basis of their morphological and also anatomical characters, measurement is of use only when the state of preservation is good enough for them not to be deformed. Also, shape changes resulting from charring are often hard to estimate.

The nomenclature follows Van Zeist 1984 (tables on the following pages). For a comparison of modern and traditional taxonomical grouping see Zohary \& Hopf 2000. 
Table 1: Wild and cultivated species of Triticum (wheat)

\begin{tabular}{|c|c|c|c|c|c|}
\hline & English & French & German & Distribution & Remarks \\
\hline $\begin{array}{l}\text { diploid ( } \mathbf{N}=14) \quad \text { hulled wheats } \\
\text { Triticum boeoticum Boiss. emend. Schiem. } \\
\text { T. boeoticum ssp. aegilopoides (Link.)Schiem. } \\
\text { T. boeoticum ssp. thaoudar (Reuter) Schiem. } \\
\text { Triticum monococcum L. }\end{array}$ & $\begin{array}{l}\text { wild einkorn wheat } \\
\text { 1-grained wild einkorn } \\
\text { 2-grained wild einkorn } \\
\text { einkorn wheat (small spelt) }\end{array}$ & $\begin{array}{l}\text { engrain sauvage } \\
\text { engrain }\end{array}$ & $\begin{array}{l}\text { wildes Einkorn } \\
\text { Einkorn }\end{array}$ & $\begin{array}{l}\text { SE. Europe, W. Asia } \\
\text { Transcaucasia } \\
\text { locally grown }\end{array}$ & $\begin{array}{l}\text { wild ancestor of } \mathrm{T} . \\
\text { monococcum } \\
\text { widely cultivated in ancient } \\
\text { times }\end{array}$ \\
\hline $\begin{array}{l}\text { tetraploid }(\mathbf{N}=\mathbf{2 8}) \text { hulled wheats } \\
\text { Triticum dicoccoides Körn } \\
\text { Triticum araraticum Jakubz. } \\
\text { Triticum dicoccum Schübl. } \\
\text { Triticum palaeocolchicum Men. } \\
\text { Triticum timopheevii Zhuk. }\end{array}$ & $\begin{array}{l}\text { wild emmer wheat } \\
\text { wild emmer wheat } \\
\text { emmer wheat } \\
\text { Kolchic emmer wheat } \\
\text { Timopheevi wheat }\end{array}$ & $\begin{array}{l}\text { amidonnier } \\
\text { sauvage } \\
\text { amidonnier }\end{array}$ & $\begin{array}{l}\text { wilder Emmer } \\
\text { Emmer }\end{array}$ & $\begin{array}{l}\text { Syro-Palestinian region } \\
\text { Transcaucasia, N. Iran } \\
\text { N. Iraq, E. Turkey } \\
\text { locally grown } \\
\text { Georgia } \\
\text { Georgia }\end{array}$ & $\begin{array}{l}\text { wild ancestor of most } \\
\text { tetraploid wheats } \\
\text { widely cultivated in ancient } \\
\text { times. }\end{array}$ \\
\hline $\begin{array}{l}\text { naked wheats } \\
\text { Triticum durum Desf. } \\
\text { Triticum turgidum L. } \\
\text { Triticum persicum Vav. (=T. carthlicum Nevski) } \\
\text { Triticum polonicum L. } \\
\text { Triticum turanicum Jacubz. (=T. orientale Perc.) } \\
\text { Triticum parvicoccum Kislev }\end{array}$ & $\begin{array}{l}\text { hard wheat (macaroni wheat) } \\
\text { rivet wheat (poulard wheat) } \\
\text { Persian wheat } \\
\text { Polish wheat } \\
\text { Khorassan wheat }\end{array}$ & $\begin{array}{l}\text { blé dur } \\
\text { blé poulard }\end{array}$ & $\begin{array}{l}\text { Hartweizen } \\
\text { Rauhweizen } \\
\text { Persischer Weizen } \\
\text { Polnischer Weizen } \\
\text { Khorassan-Weizen }\end{array}$ & $\begin{array}{l}\text { Mediterranean } \\
\text { Mediterranean } \\
\text { Iran, Iraq, Caucasis } \\
\text { S. Europe, Near Eeast, } \\
\text { India } \\
\text { Iran, Iraq }\end{array}$ & $\begin{array}{l}\text { the species identification } \\
\text { of archaeological naked } \\
\text { wheat remains ( } 4 x \text { and } 6 x \text { ) } \\
\text { is still a serious problem } \\
\text { restricted to irrigated fields } \\
\text { extinct archaeobotanical } \\
\text { species }\end{array}$ \\
\hline $\begin{array}{l}\text { hexaploid ( } \mathbf{N}=42) \quad \text { hulled wheats } \\
\text { Triticum spelta L. } \\
\text { Triticum macha Dekr. et Men. } \\
\text { Triticum vavilovii (Tum.) Jakubz. }\end{array}$ & $\begin{array}{l}\text { spelt wheat } \\
\text { Makha wheat } \\
\text { Vavilov's wheat } \\
\end{array}$ & épeautre & Dinkel (Spelz) & $\begin{array}{l}\text { Iran, Europe } \\
\text { Georgia } \\
\text { Armenia } \\
\end{array}$ & \\
\hline $\begin{array}{l}\text { naked wheats } \\
\text { Triticum aestivum } L \text { (=T. vulgare Vill.) } \\
\text { Tritcum compactum Host } \\
\text { (=T. aestivum grex aestivo-compactum Schiem.) } \\
\text { Triticum sphaerococcum Perc. }\end{array}$ & $\begin{array}{l}\text { bread wheat (common wheat) } \\
\text { club wheat } \\
\text { Indian dwarf wheat (shot wheat) }\end{array}$ & $\begin{array}{l}\text { blé tendre } \\
\text { blé compact }\end{array}$ & $\begin{array}{l}\text { Saatweizen } \\
\text { Zwergweizen } \\
\text { Indischer Kugelweizen }\end{array}$ & $\begin{array}{l}\text { temperate and } \\
\text { continental regions } \\
\text { same, of minor } \\
\text { importance } \\
\text { India }\end{array}$ & $\begin{array}{l}\text { see Triticum durum } \\
\text { in ancient times more } \\
\text { widely cultivated than } \\
\text { nowadays }\end{array}$ \\
\hline
\end{tabular}


Table 2: Wild and cultivated cereal species other than wheat

\begin{tabular}{|c|c|c|c|c|c|}
\hline & English & French & German & Distribution & Remarks \\
\hline $\begin{array}{l}\text { Hordeum spontaneum C. Koch } \\
\text { Hordeum distichum L. emend. Lam. } \\
\text { Hordeum distichum var. zeocrithon Körn. } \\
\text { (=Hordeum zeocrithon L.) } \\
\text { Hordeum distichum var. nudum } \\
\text { Hordeum agriocrithon Aberg } \\
\text { Hordeum lagunculiforme Bakhteyev }\end{array}$ & $\begin{array}{l}\text { wild two-row barley } \\
\text { two-row barley } \\
\text { dense-eared two-row barley } \\
\text { naked two-row barley } \\
\text { "wild" six-row barley }\end{array}$ & $\begin{array}{l}\text { orge sauvage } \\
\text { orge à deux rangs } \\
\text { orge nue }\end{array}$ & $\begin{array}{l}\text { Wildgerste } \\
\text { zweizeilige Gerste } \\
\text { Pfauengerste } \\
\text { Nacktgerste }\end{array}$ & $\begin{array}{l}\text { E.Medierranean, W. Asia } \\
\text { China, Japan } \\
\text { Tibet, Near East } \\
\text { Turkmenistan }\end{array}$ & $\begin{array}{l}\text { wild ancestor of all cultivated } \\
\text { barleys } \\
\\
\text { hybrid of } H \text {. vulgare and } H \text {. } \\
\text { Spontaneum } \\
\text { brittle rachised barley with } \\
\text { bottle-shaped grains; } \\
\text { reported for archaeological } \\
\text { sites in Crimea, Caucasia } \\
\text { and N. Iraq } \\
\end{array}$ \\
\hline $\begin{array}{l}\text { Hordeum vulgare L. emend. Lam. } \\
\text { Hordeum vulgare var. tetrastichum } \\
\text { (=Hordeum tetrastichum Kcke.) } \\
\text { Hordeum vulgare var. hexastichum } \\
\text { (=Hordeum hexastichum L.) } \\
\text { Hordeum vulgare var. coeleste L. } \\
\text { (=Hordeum vulgare var. nudum) }\end{array}$ & $\begin{array}{l}\text { six-row barley } \\
\text { lax-eared six-row barley } \\
\text { dense-eared six-row barley } \\
\text { naked six-row barley }\end{array}$ & $\begin{array}{l}\text { orge polystique } \\
\text { orge nue }\end{array}$ & $\begin{array}{l}\text { mehrzeilige Gerste } \\
\text { lockerährige Gerste } \\
\text { dichtährige Gerste } \\
\text { Nacktgerste }\end{array}$ & China, Japan & $\begin{array}{l}\text { important crop plant in } \\
\text { prehistoric Near East }\end{array}$ \\
\hline $\begin{array}{l}\text { Secale montanum Guss. } \\
\text { Secale cereale } \mathrm{L} . \\
\text { Secale ancestrale Zhuk. }\end{array}$ & $\begin{array}{l}\text { wild rye } \\
\text { rye } \\
\text { wild rye }\end{array}$ & $\begin{array}{l}\text { seigle sauvage } \\
\text { seigle } \\
\text { seigle sauvage }\end{array}$ & $\begin{array}{l}\text { Wildroggen } \\
\text { Roggen } \\
\text { Wildroggen }\end{array}$ & $\begin{array}{l}\text { Mediterranean, Near East } \\
\text { Europe, Turkey } \\
\text { Turkey }\end{array}$ & $\begin{array}{l}\text { perennial wild rye } \\
\text { cultivated rye and weedy rye } \\
\text { types } \\
\text { weedy rye }\end{array}$ \\
\hline $\begin{array}{l}\text { Avena sterilis } \mathrm{L} . \\
\text { Avena byzantina C. Koch } \\
\text { Avena fatua } \mathrm{L} . \\
\text { Avena sativa } \mathrm{L} .\end{array}$ & $\begin{array}{l}\text { wild red oat } \\
\text { cultivated red oat } \\
\text { common wild oat } \\
\text { common oat } \\
\end{array}$ & $\begin{array}{l}\text { folle avoine } \\
\text { avoine }\end{array}$ & $\begin{array}{l}\text { Flughafer } \\
\text { Saathafer } \\
\end{array}$ & $\begin{array}{l}\text { Mediterranean, Near East } \\
\text { Mediterranean } \\
\text { Mediterranean, Europe } \\
\text { Europe, W. Asia } \\
\end{array}$ & \begin{tabular}{|l|} 
wild \\
cultivated \\
weedy \\
cultivated \\
\end{tabular} \\
\hline $\begin{array}{l}\text { Panicum miliaceum L. } \\
\text { Setaria viridis Beauv. } \\
\text { Setaria italica (L.) Beauv. } \\
\\
\text { Sorghum bicolor (L.) Moench } \\
\text { (=Sorghum vulgare Pers.) }\end{array}$ & $\begin{array}{l}\text { broomcorn millet (proso millet) } \\
\text { green bristle-grass } \\
\text { Italian millet (foxtail millet) } \\
\text { grain sorghum }\end{array}$ & $\begin{array}{l}\text { millet } \\
\text { setaire verte } \\
\text { millet des oiseaux }\end{array}$ & $\begin{array}{l}\text { Rispenhirse } \\
\text { grüne Borstenhirse } \\
\text { Kolbenhirse } \\
\text { (Borstenhirste) } \\
\text { Körnerhirste } \\
\text { (Mohrenhirse) }\end{array}$ & $\begin{array}{l}\text { Asia, C. and SE. Europe } \\
\text { Mediterranean } \\
\text { Mediterranean, Europe } \\
\text { Africa, Asia }\end{array}$ & $\begin{array}{l}\text { occasionally reported for } \\
\text { Near eastern sites } \\
\text { wild ancestor of S. italica }\end{array}$ \\
\hline Oryza sativa L. & rice & riz & Reis & $\begin{array}{l}\text { tropical and subtropical } \\
\text { regions }\end{array}$ & $\begin{array}{l}\text { in first century B.C. cultivated } \\
\text { in Mesopotamia, in Roman } \\
\text { times in the Levant }\end{array}$ \\
\hline
\end{tabular}


Morphology of the Cereal plant (ex. wheat)

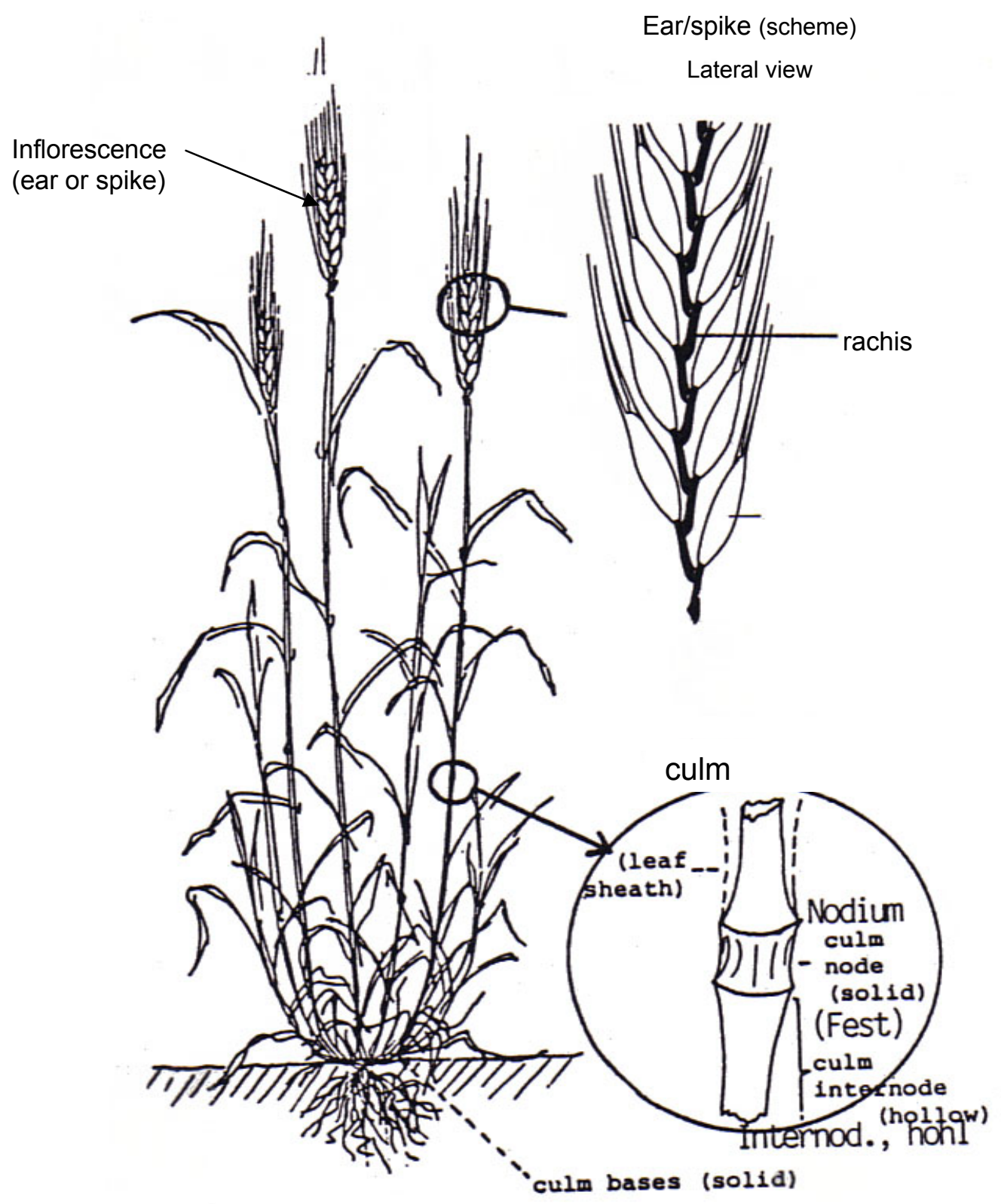

Hillman 1984 


\section{General morphology of cereal infloresences}

The commonest type of inflorescence in the cereals is the ear. All wheat and barley species and also rye have ear (spike) inflorescences. An ear is defined in the following way: the flowers (spikelets = partial inflorescences in the case of the grasses) are arranged in rows on a main axis (see part 1).

Oats and millets have their inflorescences in panicles attached to the main axis (in the case of Italian Millet, the stalks of the spikelets are very short).

In the following we shall concentrate upon ears (spikes)
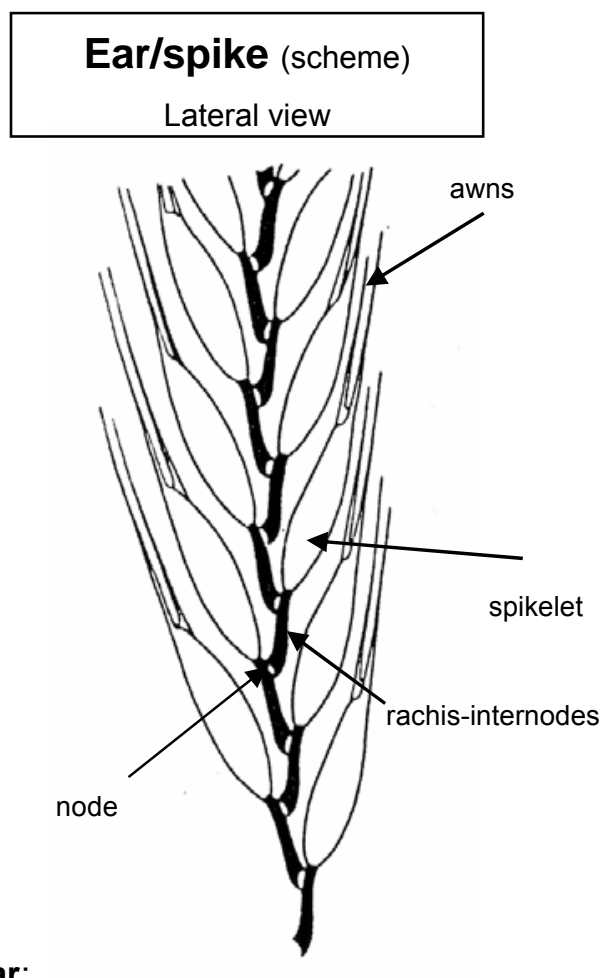

\section{Spikelet (scheme)}

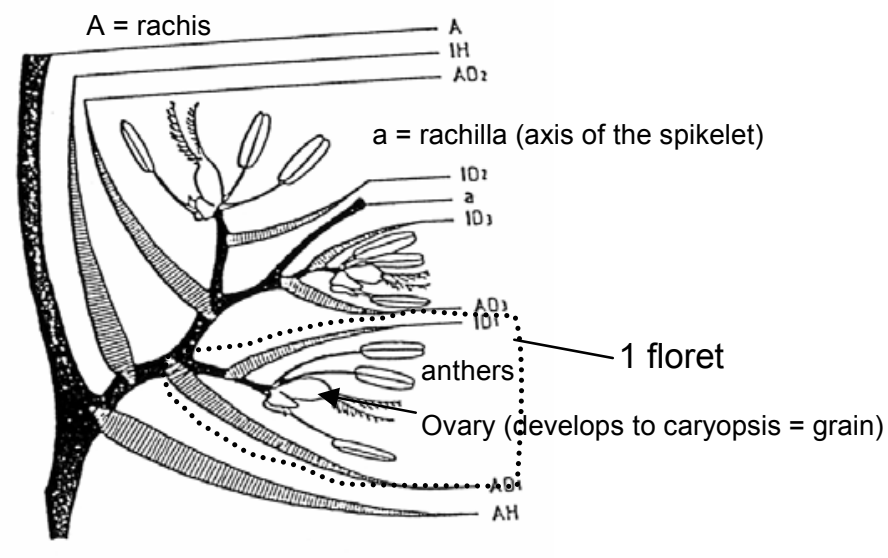

$\mathrm{IH}, \mathrm{AH}=$ glumes

$A=$ lemma, ID = palea

Kaussmann \& Schiewer 1989

Ear:

A cereal ear (spike) consists of a rachis (central axis) with attached spikelets, each with florets. The rachis (central axis) consists of rachis segments (internodes).

The rachis can be of two different kinds:

- brittle, that is easily broken into segments (spikelet with a rachis segment) at the nodes. Particularly characteristic of all wild grasses of the sub-family Triticinae (wild wheats and wild barley). The domesticated glume wheats such as einkorn and emmer have a moderately brittle rachis.

- tough, that is hardly breaking into single segments at threshing. Typical domesticated plant characteristic, particularly characteristic for example for free-threshing wheats (Triticum aestivum, T. turgidum, T.durum).

\section{Spikelet:}

basic type of inflorescence in the Gramineae (Poaceae). It consists of a group of florets on a very shortened rachis. In wild cereals the spikelet (with one rachis segment attached) is the unit of dispersal. The spikelet is one-flowered or many-flowered. It is enclosed in two glumes which can have various shapes (compare the single species).

\section{Florets:}

A grass floret is made up of 4 parts; a lemma and a palea, which enclose the ovary (which develops to the caryopsis = grain) and anthers. The lemma can have a long or short extension - an awn. When the grain is held fast in the lemma and palea, one is dealing with a hulled (glumed) cereal. With these the grain needs to be got out from the lemma and palea by processes such as parching in an oven of pounding in a mortar. When the grain is only loosely held between the lemma and palea, these are the free-threshing or naked cereals. 


\section{(= one-seeded, syncarpous nutlet, pericarp and testa fused)}

On the dorsal side of the grain one can see the embryo, which will develop into the young plant. It is more or less sunk into a cavity. The interior of the grain consists of endosperm, a nutritional tissue which mainly contains starch. On the ventral side is, sunk into a furrow, the elongated (lineal) hilum. The grain is enclosed in a series of layers:

- the pericarp which contains vitamins and minerals

- the testa (seed coat)

- the aleurone layer, which mainly contains proteins.

\section{outside view:}

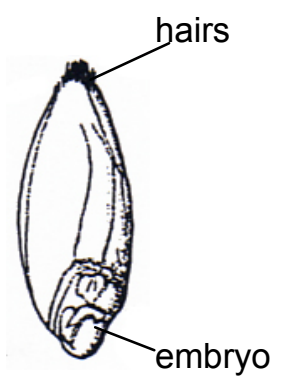

dorsal

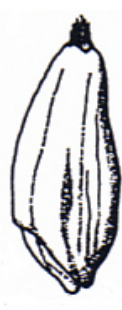

lateral

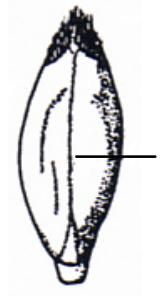

ventral
Furrow on the

ventral side, with

narrow, lineal hilum

\section{cross section:}

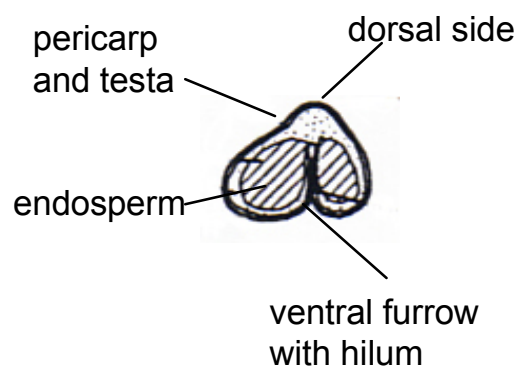

section:

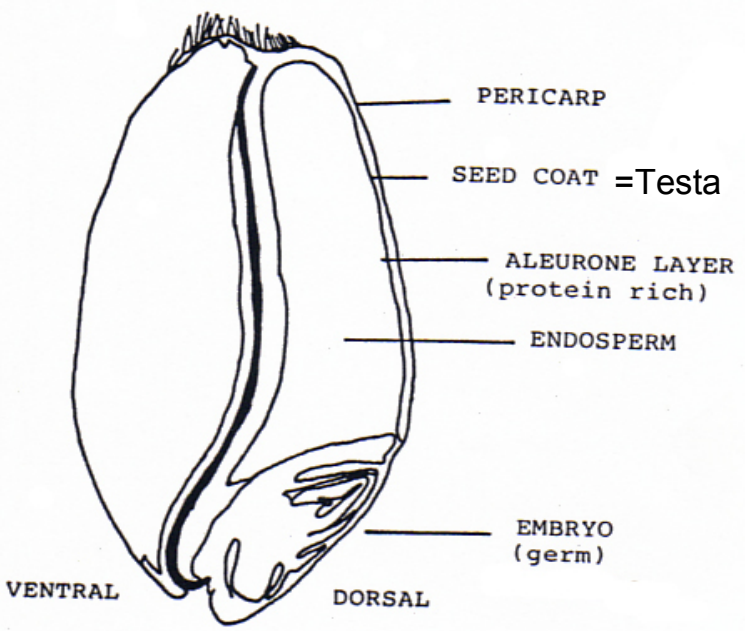

Charles 1984

\section{cross section through pericarp, testa etc.}

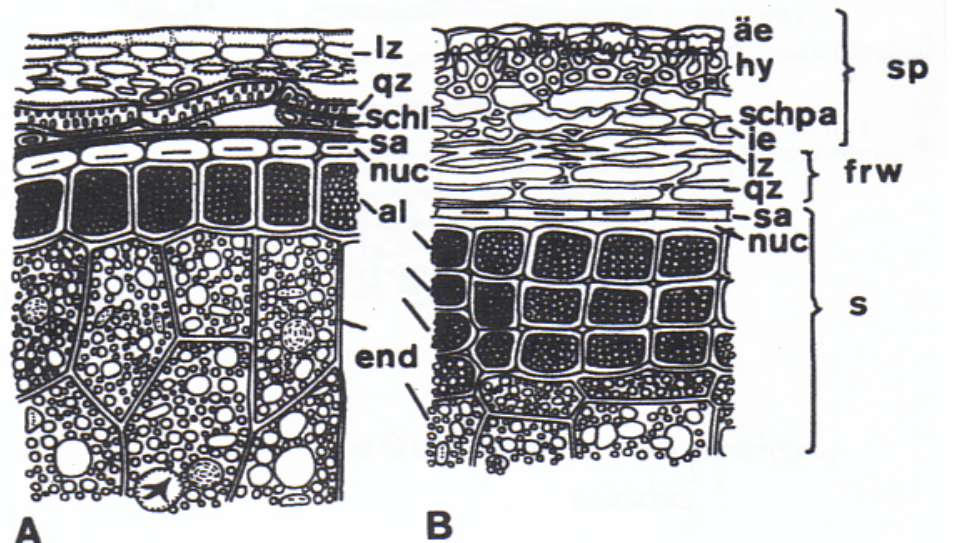

(the same holds for all grass fruits)
A Secale cereale: Iz=longitudinal cells; $q z=$ cross cells; schl=tube cells; sa=testa (seed coat); nuc=remains of the nucellus; al=aleurone cells; end=endosperm

B: Hordeum vulgare: äe=outer epidermis; ie=inner epidermis; hy=hypodermis; schpa=spongy parenchyma; $s p=$ lemma; frw=pericarp; $\mathrm{s}=$ seed; other abbrev. see $\mathrm{A}$.

\section{After Gassner 1951}


The diagnostically important characters of the remains are given in the tables (see list). Well-preserved objects are measured at the points given (Measurements: see Fig.'s). Various indices are calculated from the collected measurement data (see single species). The objects are assigned to a particular taxon according to the morphological data and the interpretation of the metrical data. The objects are also drawn or photographed for publication.

\section{measurement points in cereals (1)}
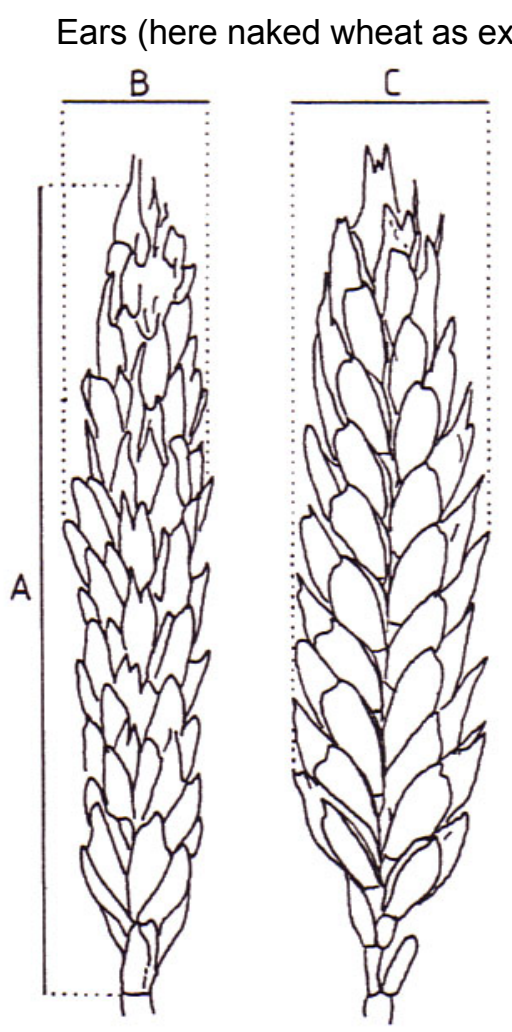

Spikelet, spikelet fork (glume wheat)

(ab)axial view
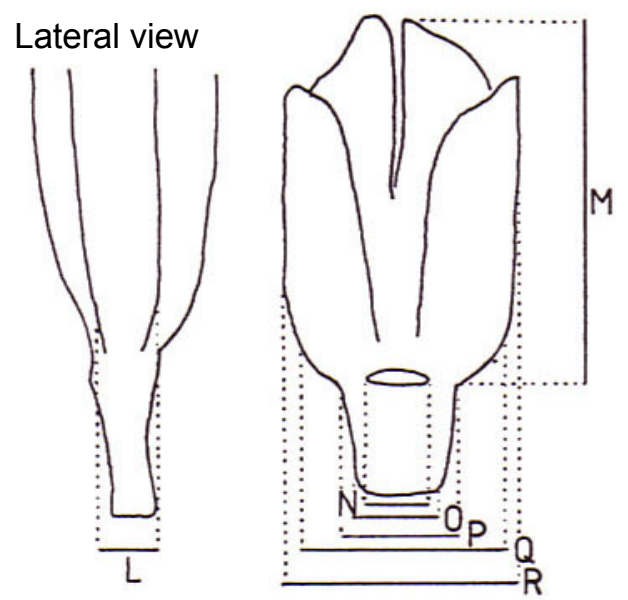

More details see under glume wheat chaff!

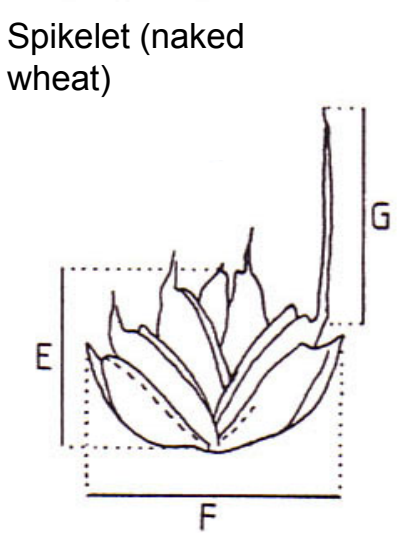

Glume (wheat)

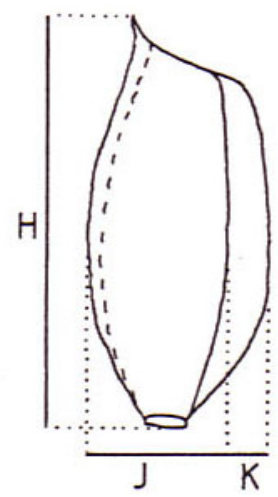

A: length of the ear

$\mathrm{B}$ : width of the ear (axial view)

C: width of the ear (lateral view)

$D$ : length of the rachis

$\mathrm{E}$ : length of the spikelet

F: max. breadth of the spikelet

$\mathrm{G}$ : length of the awn

$\mathrm{H}$ : length of the glume

Rachis, with

several internodes

$\mathrm{J}$ : width of the glume (between primary and secondary keel)

$\mathrm{K}$ : width of the remaining part of the glume

$\mathrm{L}$ : width of the glume-base

$M$ : length of the spikelet

$\mathrm{N}$ : breadth of the upper scar

$\mathrm{O}$ : width of the base of the internode (=lower scar)

$\mathrm{Q}$ : width of the spikelet-base (at the upper margin of the upper scar)

$\mathrm{R}$ : max. width of the spikelet 
Rachis-internodes (barley)
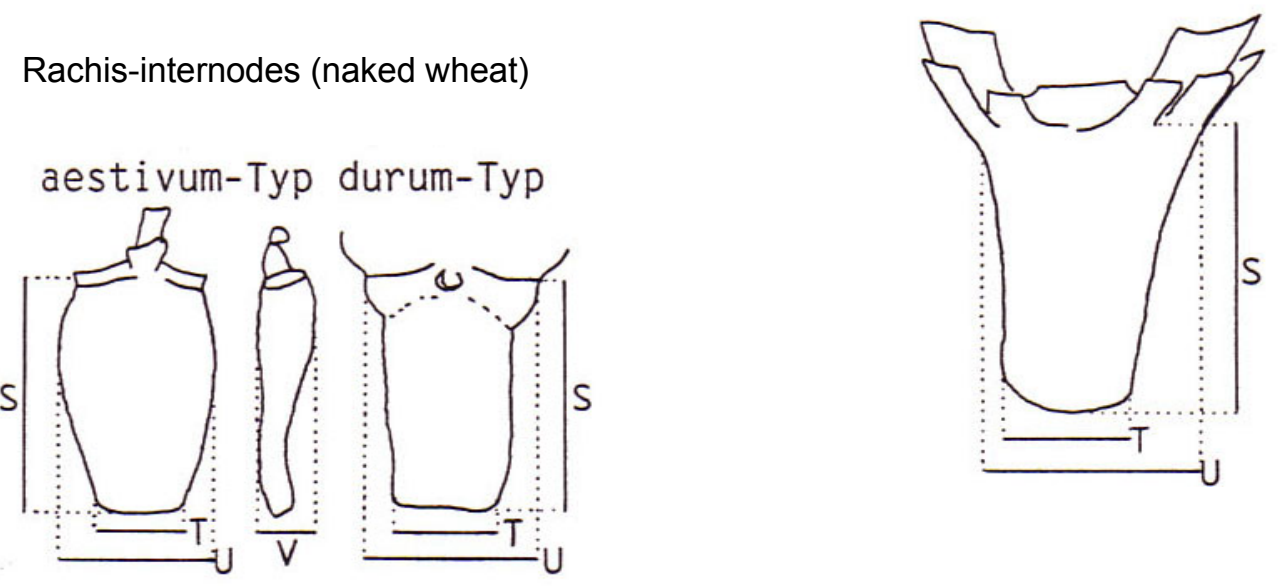

$S$ : lenth of the internode (rachis segment)

$\mathrm{U}$ : max. breadth of the internode $\mathrm{T}$ : breadth of the internode-base (lower scar) $\mathrm{V}$ : max. thickness of the internode (more details see under naked wheat)

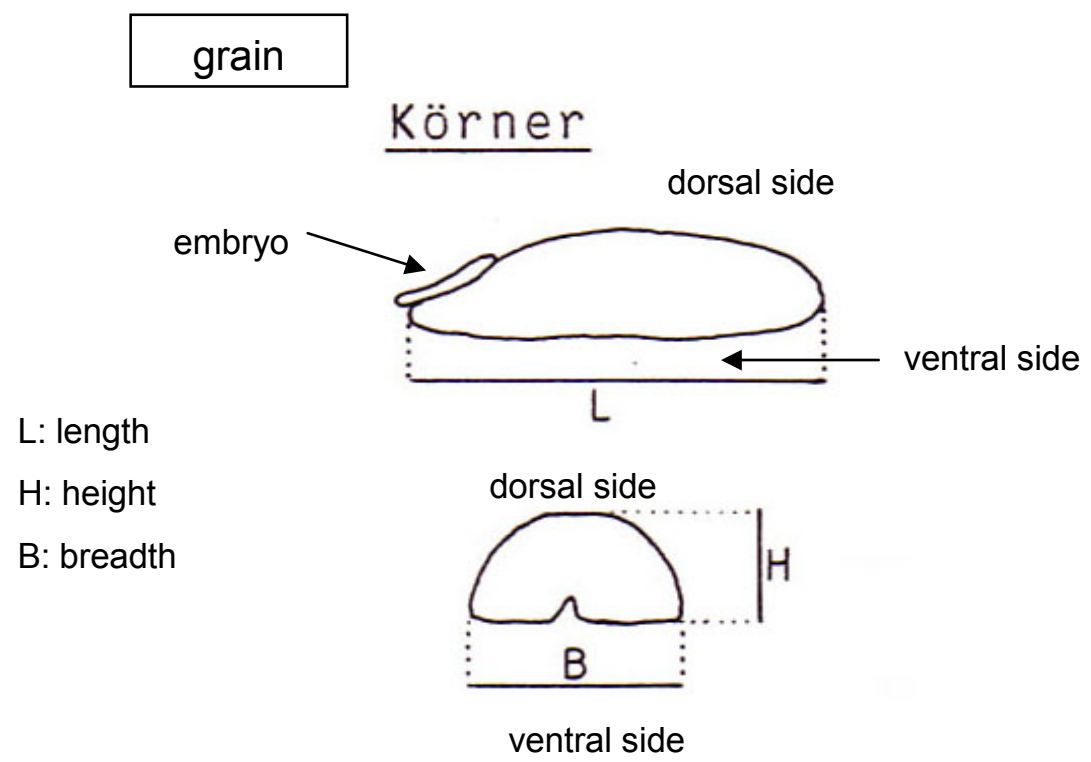




\section{Wheat (Triticum)}

Inflorescences (1)

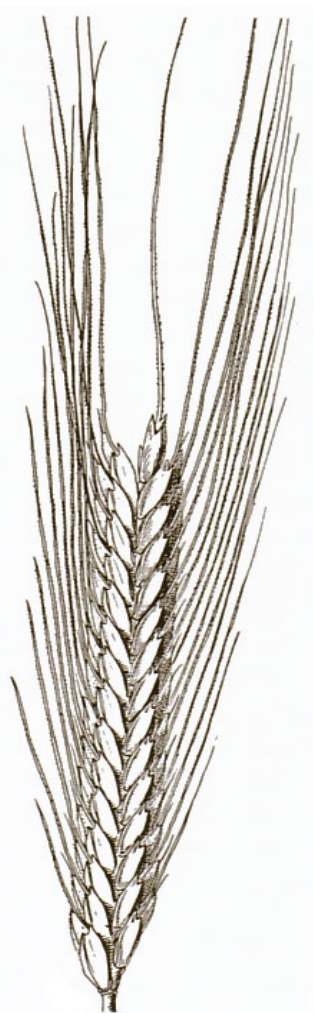

Triticum

monococcum (diploid, glume wheat)

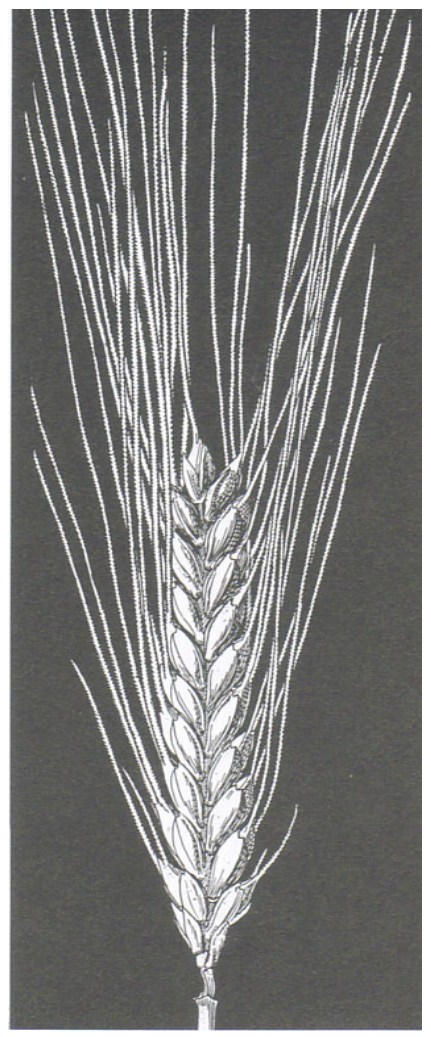

Triticum dicoccum (tetraploid, glume wheat)
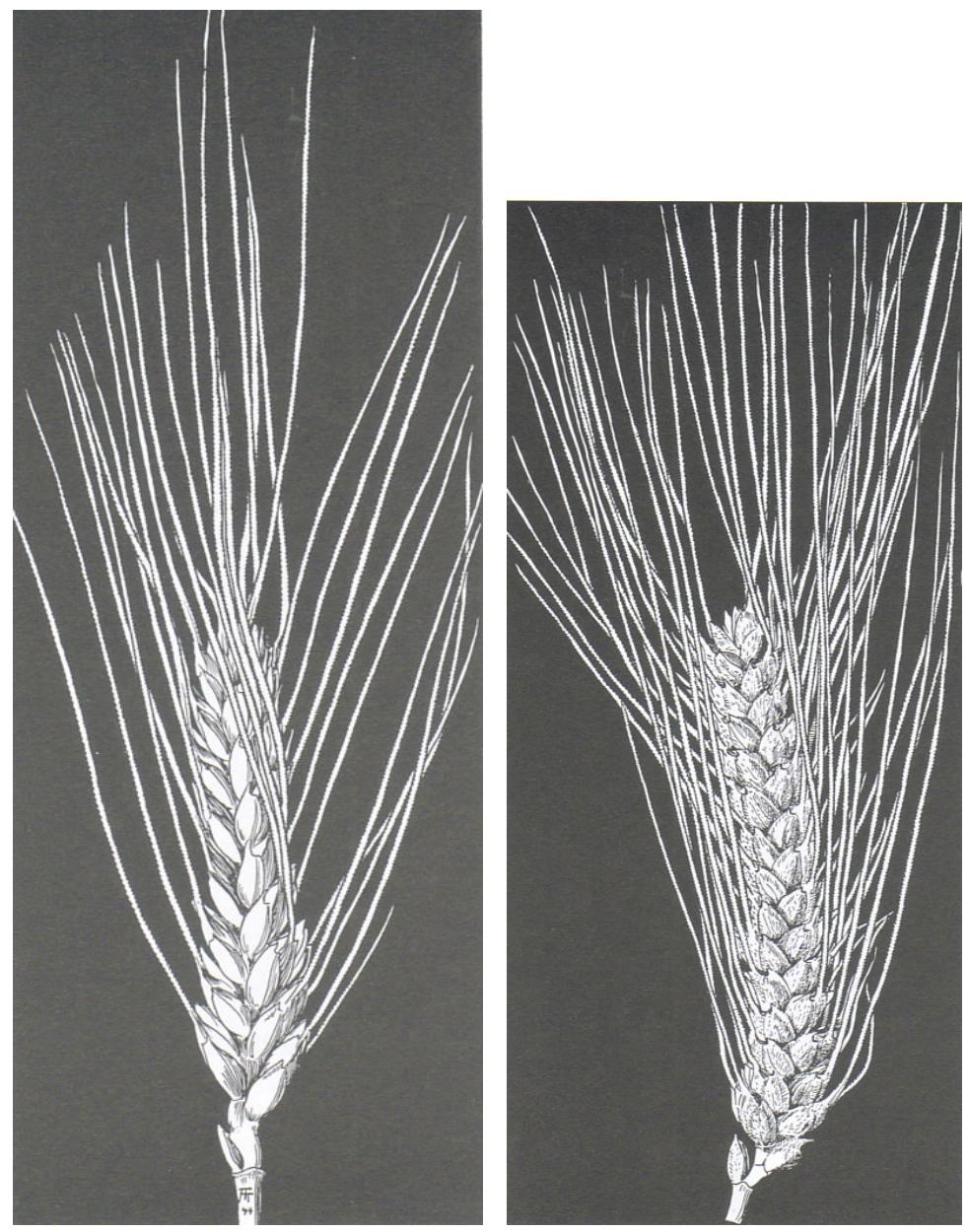

Triticum durum

(tetraploid, naked wheat)
Triticum turgidum

(Tetraploid, naked wheat) 


\section{wheat (Triticum) (inflorescences, contin.)}

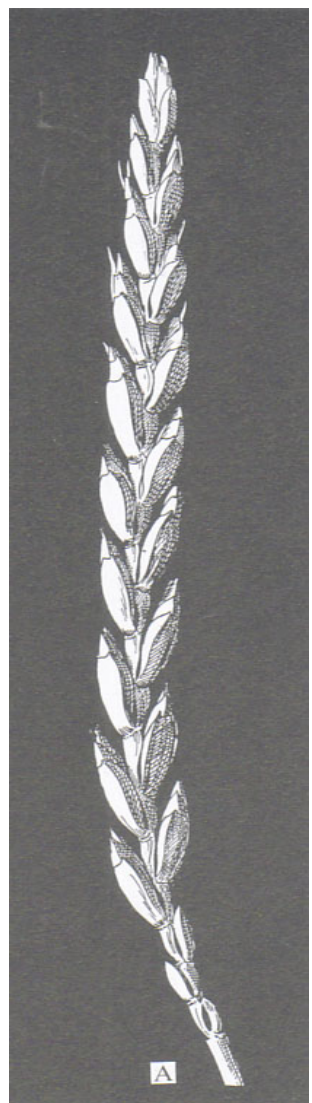

Triticum spelta

hexaploid, glume wheat

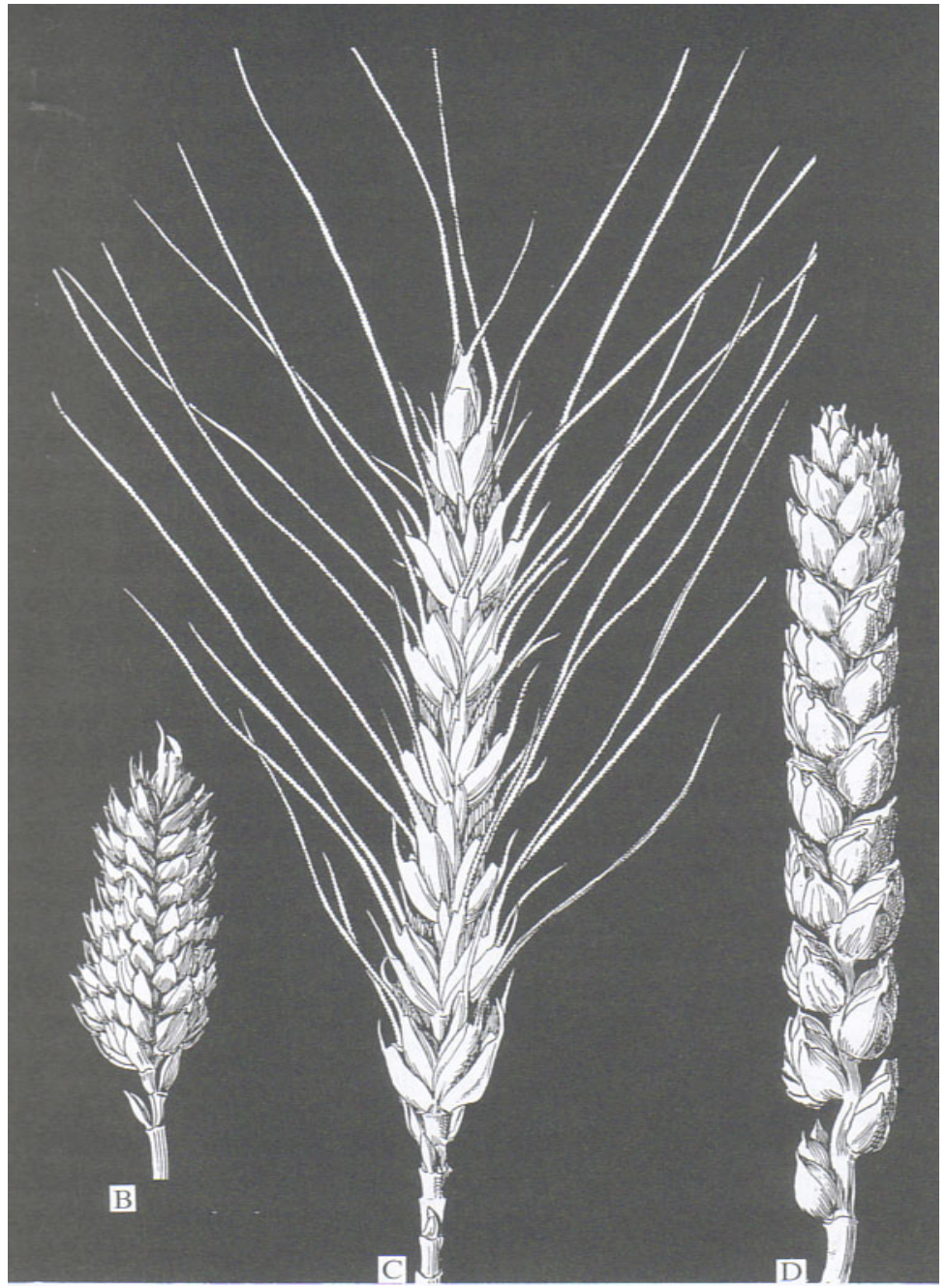

Triticum aestivum (hexaploid, naked wheat)

B: ssp. compactum ssp. vulgare

C: with awns

D: without awns 


\section{wheat: taxonomy, varieties}

Wheat species resp. varities can be classified according to two possible criteria:

a) according to ploidy level, also the chromosome number.

b) according to the type of glume attachment: there are glumed (hulled) and free-threshing (naked) wheat forms.

b1) Glumed (hulled) wheats: thick gripping glumes enclose the grain tightly. The grain cannot be easily extracted from the spikelets; the ears usually break into spikelets. To obtain naked grains the spikelets must be roasted (parched) and also pounded (see e.g. Hillman 1984). In this group belong:

Diploids: Einkorn (Triticum monococcum)

Tetraploids: Emmer (Triticum dicoccum)

Hexaploids: Spelt (Triticum spelta)

b2) Naked wheats: The grains are only loosely held in the glumes. In ripe ears the grains are visible from the outside. The glumes are generally less thickened and woody than in glume wheats. The grains can be easily freed from the ears with threshing. In this group belong:

Tetraploids: maccaroni wheats (Triticum durum)

rivet (pollard) wheats (T. turgidum)

Hexaploids: bread wheats (Triticum aestivum)

\begin{tabular}{|c|c|c|c|c|c|c|}
\hline \multicolumn{4}{|c|}{ Table 1|Species and their derived forms } & \multicolumn{3}{|c|}{ Salamini et al. 2002} \\
\hline $\begin{array}{l}\text { Species names } \\
\text { in this review } \\
\text { (common name) }\end{array}$ & Biological species & $\begin{array}{l}\text { Genome } \\
\text { and ploidy }\end{array}$ & $\begin{array}{l}\text { Ear and } \\
\text { seed traits }\end{array}$ & $\begin{array}{l}\text { No. of loci } \\
\text { that support } \\
\text { B vs NB } \\
\text { rachis* }\end{array}$ & $\begin{array}{l}\text { Alleles of loci that } \\
\text { affect either glume } \\
\text { or glume and ear } \\
\text { rachis (chromosome) }\end{array}$ & References \\
\hline $\begin{array}{l}\text { T. boeoticum } \\
\text { (wild einkorn) }\end{array}$ & $\begin{array}{l}\text { T. monococcum L. } \\
\text { ssp. boeoticum Boiss. }\end{array}$ & AA & $\mathrm{H}, \mathrm{B}$ & 2 & $\operatorname{Sog}_{A}(2 S)$ & 27 \\
\hline $\begin{array}{l}\text { T. monococcum } \\
\text { (cultivated einkorn) }\end{array}$ & $\begin{array}{l}\text { T. monococcum L. } \\
\text { ssp. monocoocum }\end{array}$ & AA & $\mathrm{H}, \mathrm{NB}$ & 2 & $\operatorname{Sog}_{A}(2 S)$ & 27,29 \\
\hline $\begin{array}{l}\text { T. urartu } \\
\text { (wild T. urartu) }\end{array}$ & T. urartu Tuman. & AA & $\mathrm{H}, \mathrm{B}$ & 2 & - & - \\
\hline $\begin{array}{l}\text { Ae. tauschii } \\
\text { (wild Ae. Tauschi) }\end{array}$ & Ae. tauschï Coss. & $\mathrm{DD}$ & $\mathrm{H}, \mathrm{B}$ & 1 & $\operatorname{Tg}_{0}(2 \mathrm{~S})$ & 51,52 \\
\hline $\begin{array}{l}\text { T. dicoccoides } \\
\text { (wild emmer) }\end{array}$ & $\begin{array}{l}\text { T. turgidum L. } \\
\text { ssp. dicoccoides Aschers. }\end{array}$ & AABB & $\mathrm{H}, \mathrm{B}$ & 2; polygenic & $\begin{array}{l}T g 2_{B}(2 S), q_{A}^{\S}(5 L) \\
Q f t_{5 A}(5 S), Q t_{6 A}(6)\end{array}$ & $\begin{array}{r}44,50,56,114,115 \\
116,117\end{array}$ \\
\hline $\begin{array}{l}\text { T. dicoccum } \\
\text { (cultivated emmer) }\end{array}$ & $\begin{array}{l}\text { T. turgidum L. } \\
\text { ssp. dicoccum Schübl. }\end{array}$ & AABB & $\mathrm{H}, \mathrm{NB}$ & 2 & $\operatorname{Tg} 2_{B} \|(2 S), q_{A}(5 L)$ & 50,116 \\
\hline $\begin{array}{l}\text { T. durum } \\
\text { (hard wheat) }\end{array}$ & $\begin{array}{l}\text { T. turgidum L. } \\
\text { ssp. dunum Desf. }\end{array}$ & AABB & $\mathrm{FT}, \mathrm{NB}$ & polygenic & $\begin{array}{l}\operatorname{tg} 2_{B}(2 S), Q_{A}(5 L) \\
q f_{5 A}(5 S), q t_{G A}(6)\end{array}$ & $50,51,56,114,116,118$ \\
\hline $\begin{array}{l}\text { T. parvicoccum } \\
\text { (T. parvicoccum, } \\
\text { archaeobotanical) }\end{array}$ & $\begin{array}{l}\text { T. turgidum L. } \\
\text { ssp. parvicoccum Kislev }\end{array}$ & (AABB) & $\mathrm{FT}, \mathrm{NB}$ & - & - & - \\
\hline $\begin{array}{l}\text { T. araraticum } \\
\text { (wild Timopheev's } \\
\text { wheat) }\end{array}$ & $\begin{array}{l}\text { T. timopheevil Zhuk. } \\
\text { ssp. araraticum Jakubz. }\end{array}$ & AAGG & $\mathrm{H}, \mathrm{B}$ & - & - & - \\
\hline $\begin{array}{l}\text { T. timopheevï } \\
\text { (cultivated } \\
\text { Timopheev's wheat) }\end{array}$ & $\begin{array}{l}\text { T. timopheevii Zhuk. } \\
\text { ssp. timopheevil }\end{array}$ & AAGG & $\mathrm{H}, \mathrm{NB}$ & - & - & - \\
\hline $\begin{array}{l}\text { T. spelta } \\
\text { (spelt) }\end{array}$ & $\begin{array}{l}\text { T. aestivum L. } \\
\text { ssp. spelta }\end{array}$ & AABBDD & $\mathrm{H}, \mathrm{NB}$ & 2 & $\begin{array}{l}T g 2_{B} T g_{D}(2 S), q_{A}(5 \mathrm{~L}) \\
Q f t_{5 A}{ }^{1}(5 S), Q t_{G A}{ }^{\prime}(6)\end{array}$ & $53,55,108,114,119$ \\
\hline $\begin{array}{l}\text { T. vulgare } \\
\text { (bread wheat) }\end{array}$ & $\begin{array}{l}\text { T. aestivum L. } \\
\text { ssp. vulgare Host. }\end{array}$ & AABBDD & $\mathrm{FT}, \mathrm{NB}$ & 2 & $\begin{array}{l}\operatorname{tg} 2_{B} \operatorname{tg}_{D}, Q_{A}{ }^{\pi} \\
q f t_{G A}, q t_{G A}\end{array}$ & $44,48,51,116$ \\
\hline
\end{tabular}

Nomenclature is taken from REF. 5, with modifications. "Genes that affect rachis but not glume traits. ${ }^{1}$ Subscripts indicate genomes. ${ }^{5}$ Designated as 92 in REF. $56.1 /$ Allele inferred from genotype of wild emmer. 1Allele inferred from genotype of hard wheat. *The trait is under the $\infty$ ntrol of the single gene $N$ (recessive $n$, naked seeds) ${ }^{80}$. Ae. Aegiops; B, brittle rachis, ears disarticulating at maturity into spikelets; $F$, free-threshing, soft glumes, shorter rachis internode, tougher rachis; $\mathrm{H}$, hulled wheat, in the spikelet, the kernels of $\mathrm{H}$ wheats are covered by tenacious glumes, not easily separated from grains during threshing; $H$. . $H$ ordeum; $\mathrm{NB}$, non-brittle, non-brittle (tough) rachis that does not disarticulate at maturity; Q, Q factor; S., Secale; Sog, tenacious glumes; $T$., Thiticum; Tg, tenacious glumes.

\section{Origin:}

Genetics: Wild grasses with $2 n=14$ chromosomes (wild einkorn = Triticum boeoticum s.l., Aegilops species (genome AA, BB or DD) and finally also Agropyron species) and those with $2 n=28$ chromosomes (wild emmer = Triticum dicoccoides, genome AABB) . 


\section{wheat: phylogeny}

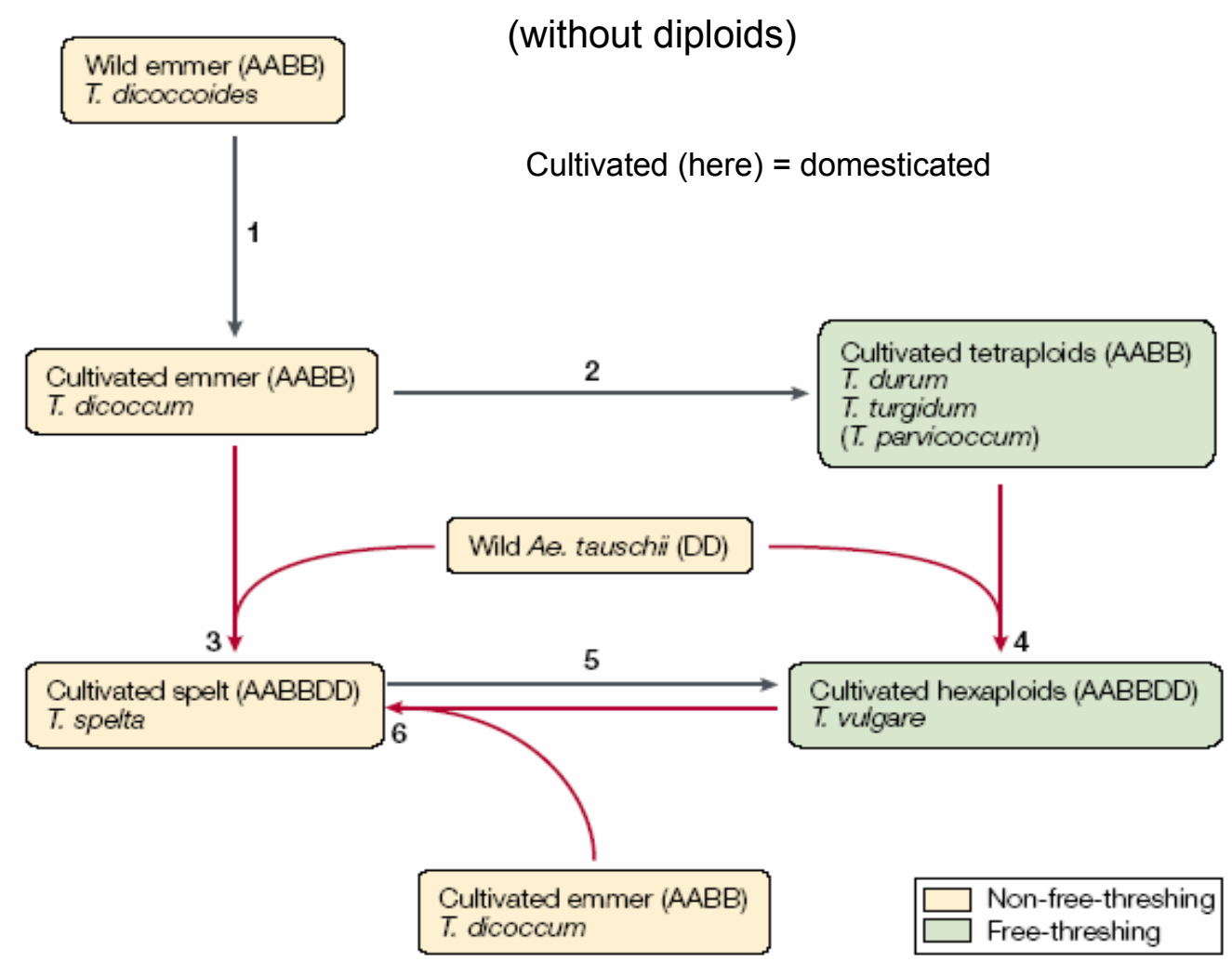

Flgure 4 | Models for the evolution of polyploid wheats under cultivation and domestication. The red arrows indicate hybridlzation events; the black arrows show domestication events (see text for detalls). Ae., Aegllops; T., Triticum.

Salamini et al. 2002

Morphological points: Spikelets many-flowered. Glumes wide (broad), lemmas with or without awns.

\section{Most important morphological characters of the finds}

Grains: wheat grains can - according to species - have very different appearances. They are usually oval or drop-shaped in outline (see figures on the following pages).

Rachis segments: elongated, mostly more or less rectangular, with straight or curved sides. In some species the wide bases of the glumes remain attached to the rachis (see figures on the following pages). 
The most important parts of Triticum (wheat) ears, spikelets:

\section{Glume (hulled) wheat (einkorn, emmer, spelt)}
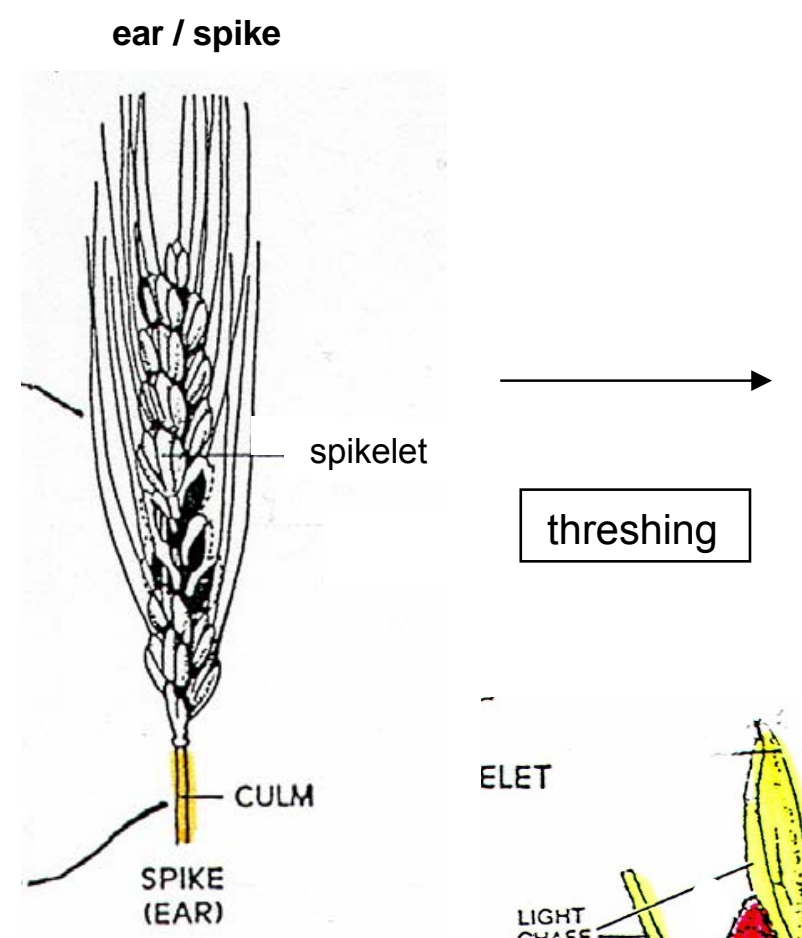

spikelet
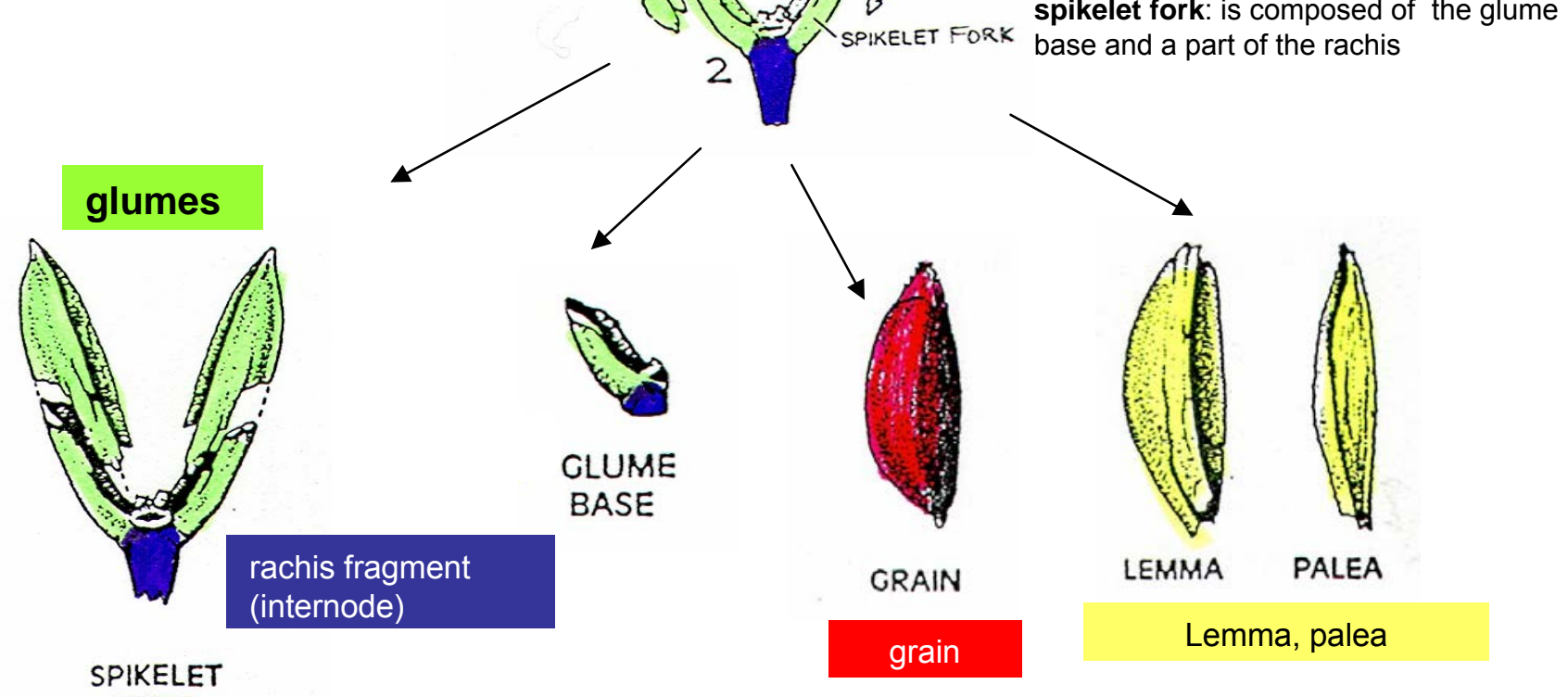

SPIKELET
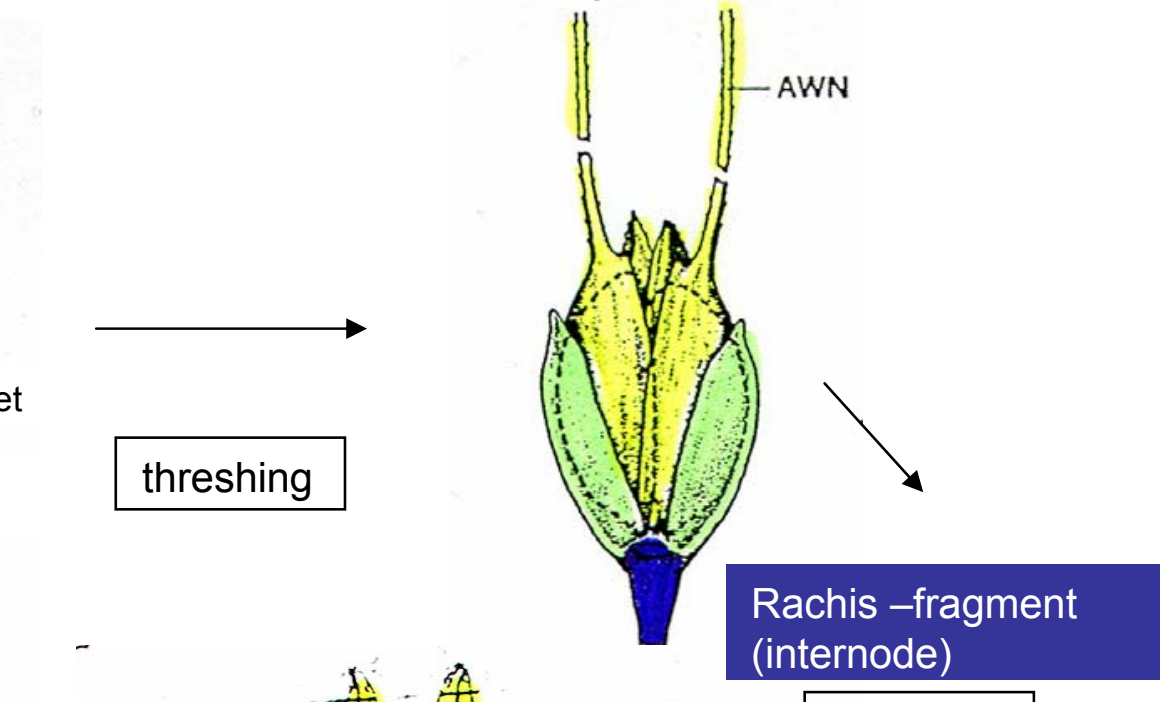
The most important parts of cereal ears (Triticum):

Naked wheat: scheme of a spikelet: bread wheat $(6 n): T$. aestivum

Axial view:

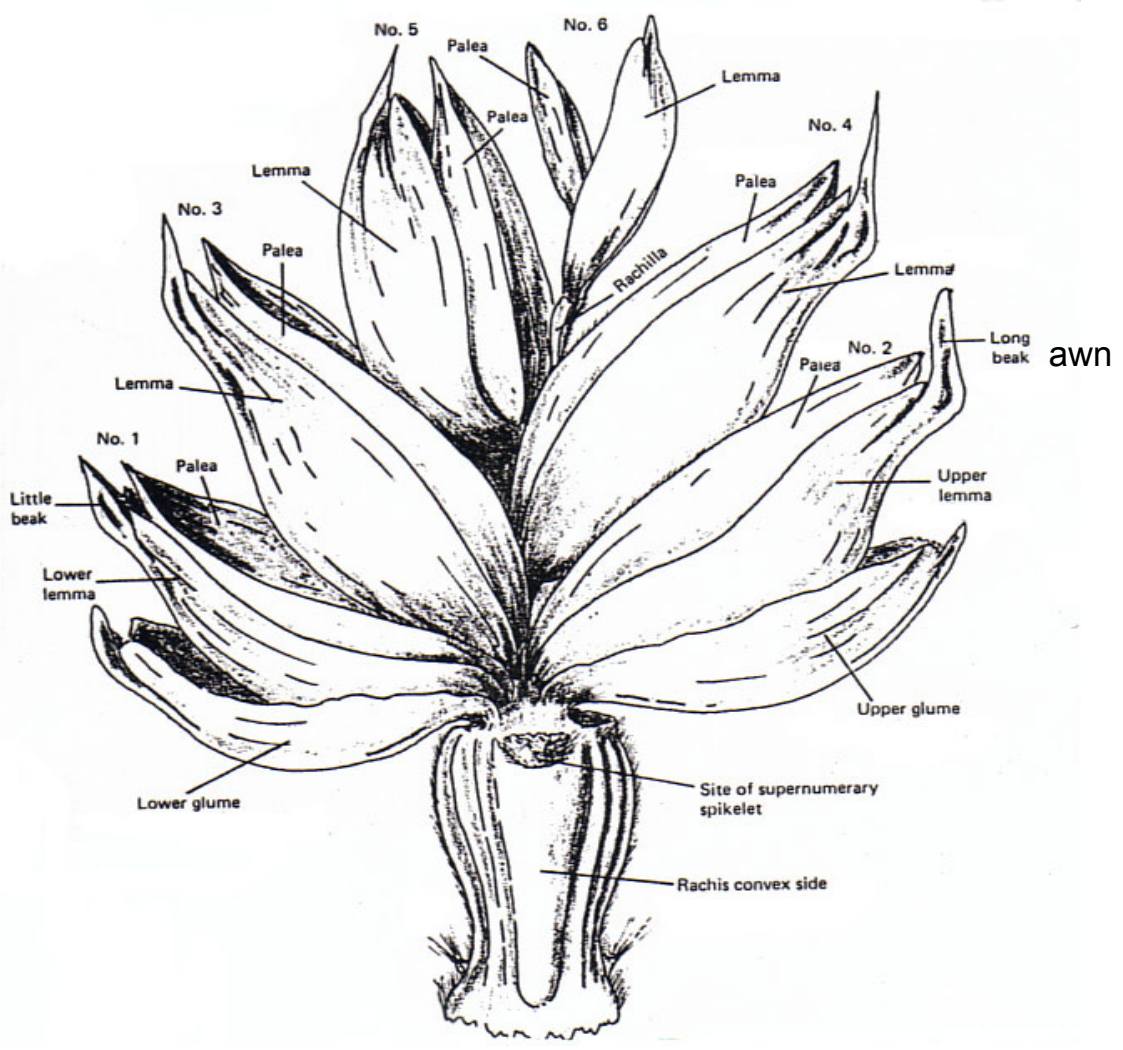

axial section:

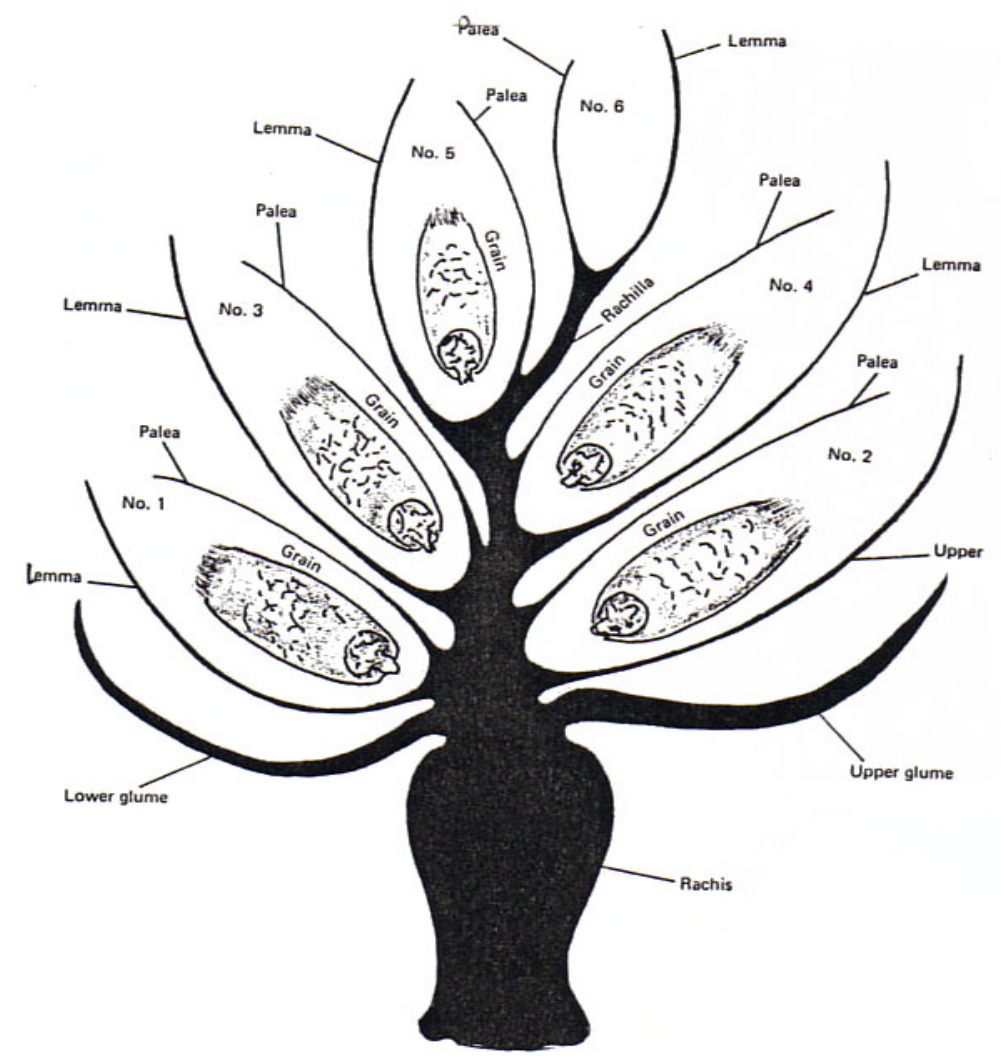


Naked wheat: parts of the spikelet after threshing

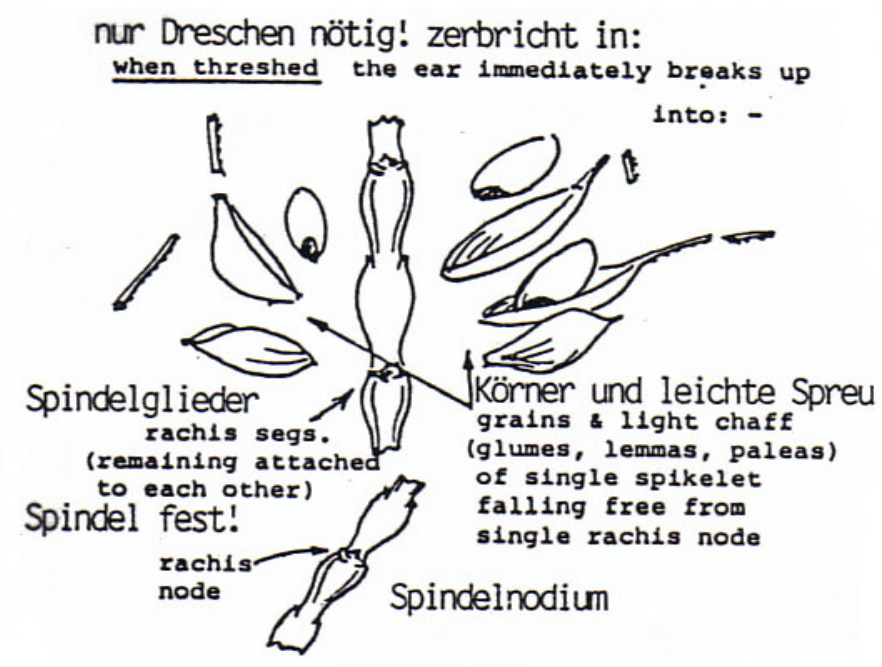

Hillmann 1984

Schematic drawing:
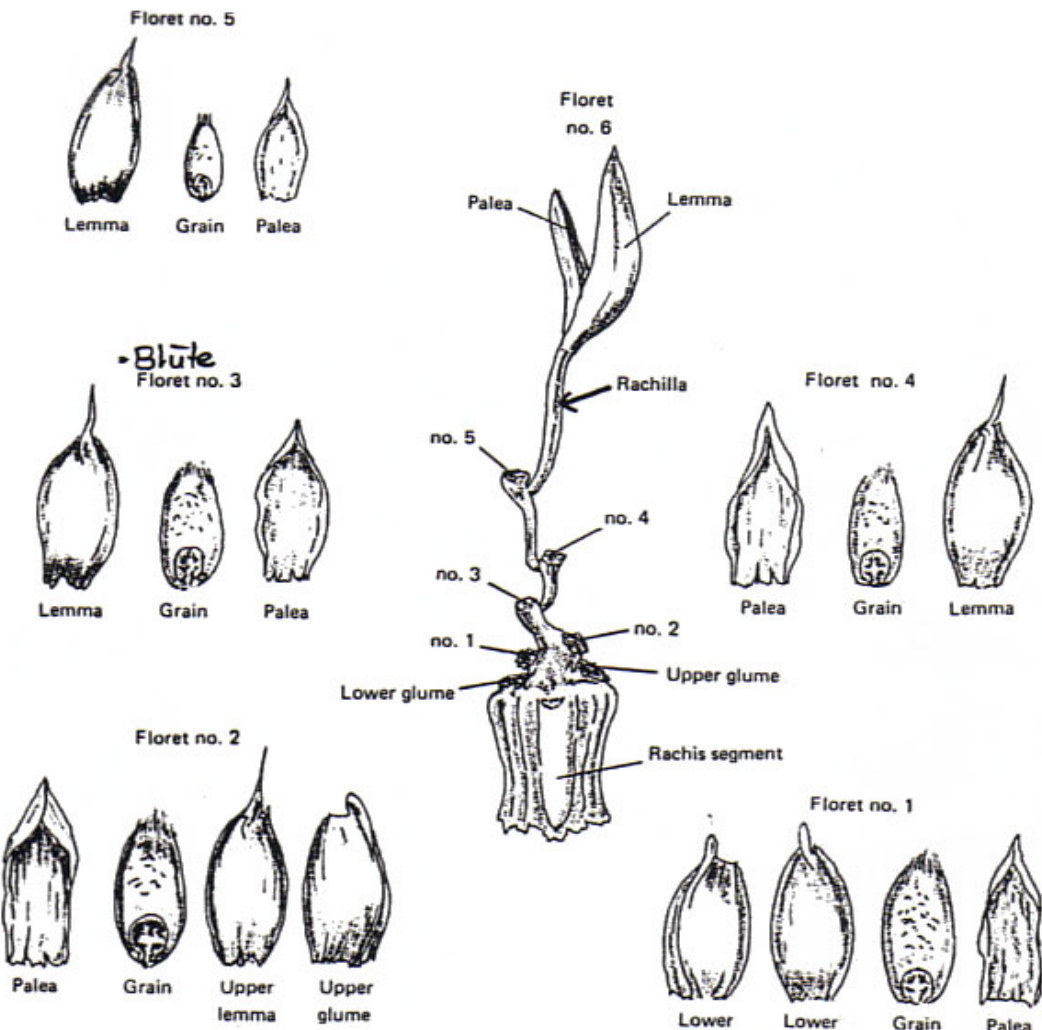


\title{
Identification of charred grains of prehistoric wheat species
}

\author{
Important characters of the wheat grain
}

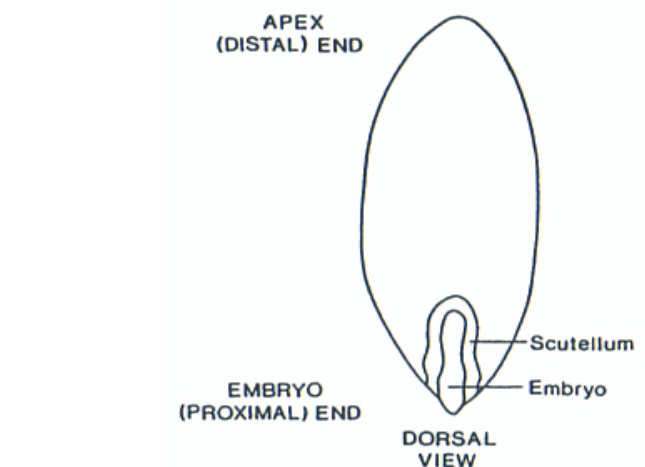

Hillman et. al. 1996
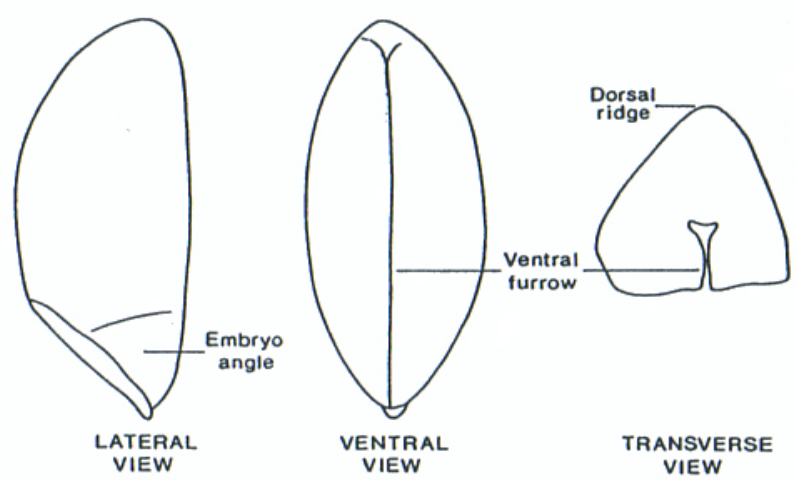

\section{Procedure}

Wheat grains are mostly found in a charred state. In waterlogged sediments however there may be many uncarbonised pericarp- and testa-remains, mostly in a fragmentary state. For their identification a special effort is needed (see e.g. Körber-Grohne 1981; Dickson 1989). We will not treat this here.

When dealing with carbonised grains it is important first to make a note of the state of preservation.

a) preservation good, no distortions or damage visible

b) preservation OK, but some damage

c) grain pop-corn-like, with starch protruding

d) grain fragmented

Secondly, the shape from above (dorsal view), from the ventral side (ventral view), from the side (lateral view) and in cross section should be noted and recorded (see criteria-list). Additionally, the shape of the ventral furrow, the position of the embryo, structure of the grain's outer surface and finally hairs at the apex of the grain should be observed and noted down. Finally, some well-preserved grains should be measured (length, breadth, height; see meaurement-lines); different indices (ratios) can then be calculated from the measurement data. The individual wheat species generally have a characteristic shape (combination of characters) and also characteristic measurement indices (see below).

For the characteristics of the individual species see the following pages.

\section{Comment}

Although there is a whole series of morphological characters, of which the ones for the identification of wheat grains to species can be summarised here, the actual species identification is often difficult. This has various causes (e.g.

Knörzer 1970 p. 33; Hillman et al. 1996; the author's observations):

- The morphological similarities between the grains of the different species are large already.

- Grains of one and the same species can vary greatly in their appearance, for example caused by their position in the ear and/or the spikelet

- The intraspecific and regional variation within a species alter the appearance and dimensions greatly.

- The changes in appearance from charring are large.

- Shapes are changed differently according to the conditions of charring.

In spite of all difficulties it is usually possible to identify wheat grains. Above all, a good state of preservation is needed. It is also very helpful when one also finds chaff remains in a grain sample (especially rachis segments and glumes), for these often provide better diagnostic characters than the grains. If one finds samples of pure grain, identification to species can be difficult (compare this with Jäger 1966, Hajnalova 1978, Knörzer 1970, Dalnoki \& Jacomet 2002 and many others). Only some species have a so generally characteristic shape that their certain identification is possible (einkorn, for example, as long as it is one-grained). The separation of emmer and spelt can be difficult, and also there are no (or only very vague) useable characters for the differentiation of the grains of the various species groups of freethreshing (naked) tetraploid wheats (macaroni and rivet wheats) and hexaploids (bread wheats). For the latter see Kislev 1984, and below, individual species. 
wheat grains: comparison of the different species

Triticum monococcum: einkorn, « normal shape »
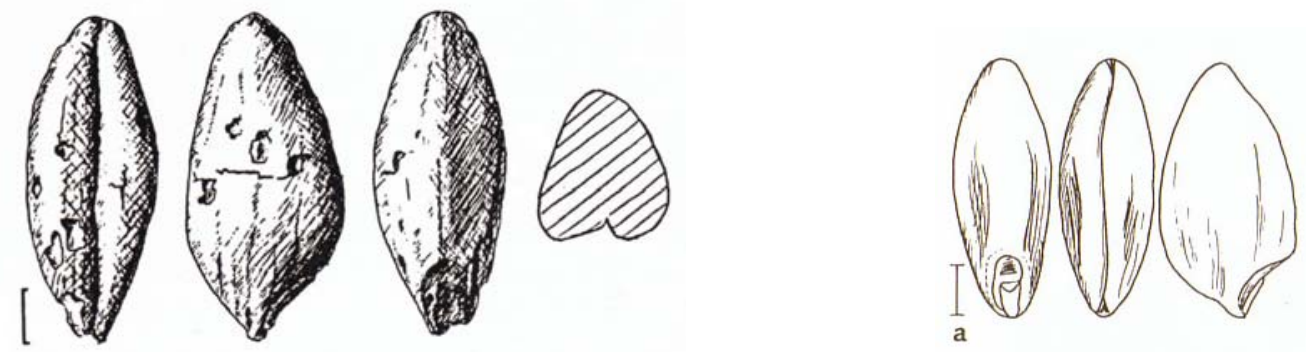

Triticum dicoccum: emmer "normal" shape
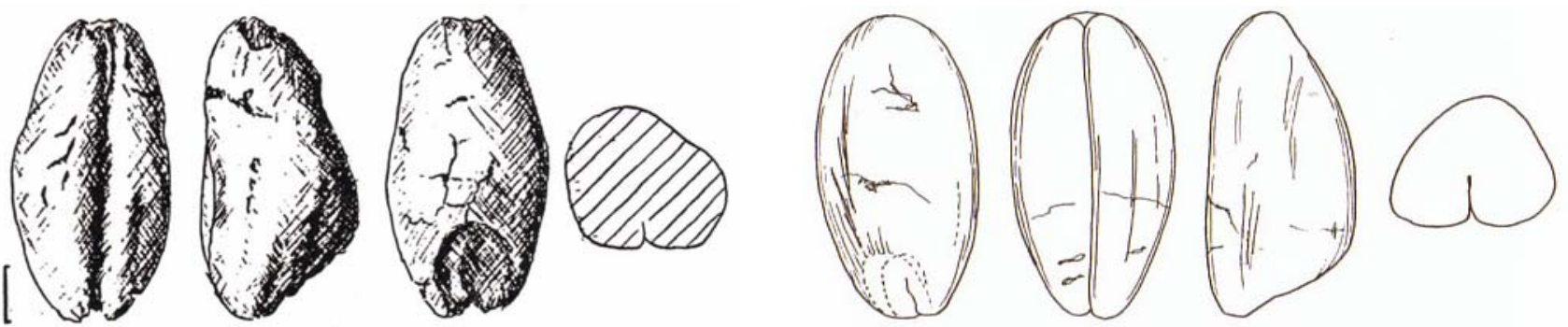

Triticum dicoccum: emmer, drop-shape
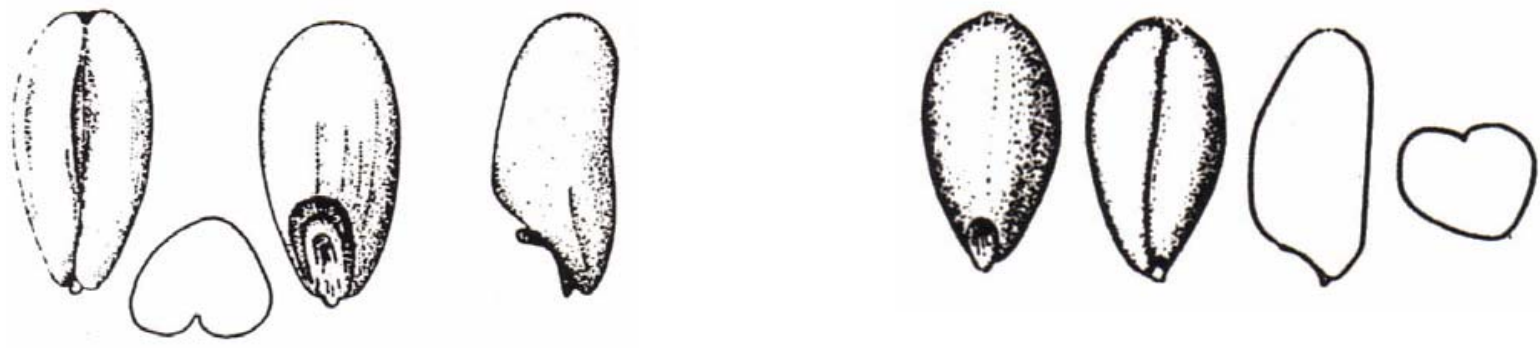

Triticum spelta: spelt, left: normal shape, right: drop-shape
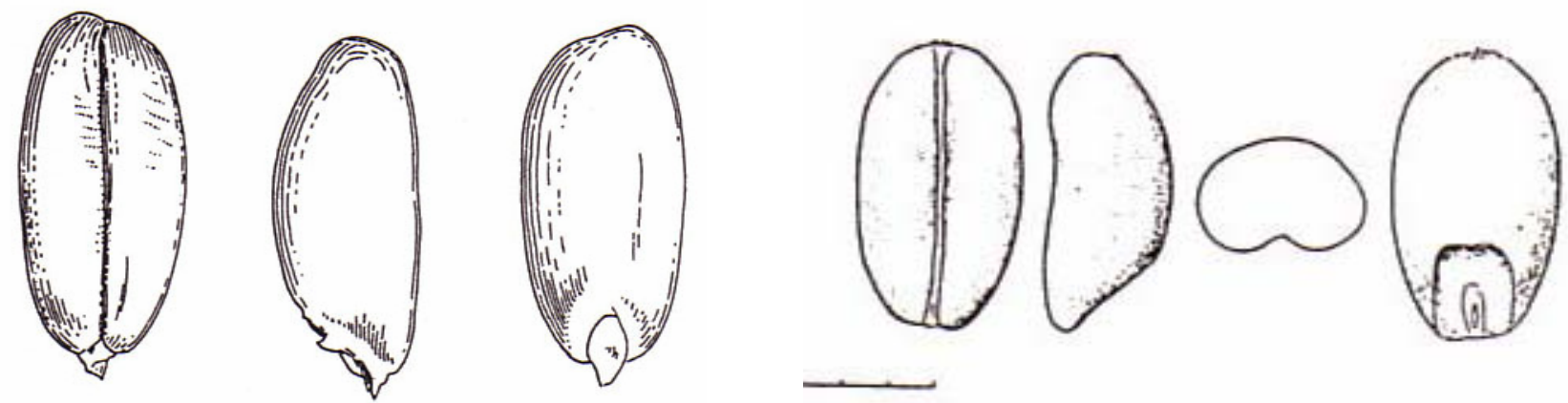

Triticum aestivum/durum/turgidum: naked wheat: left: spherical form, right: oval form
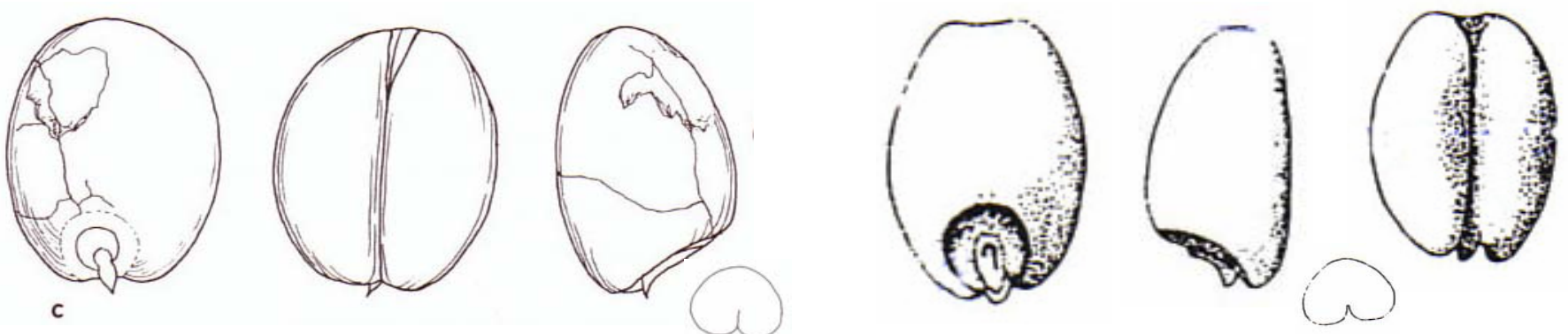

examples from: Knörzer 1967 (LBK, early Neolithic, Germany): Kohler-Schneider 2001 (Late Bronze Age, Austria); Kroll 1975 (Bronze Age, Germany); Hopf 1968 (Neolithic, Germany); Jacomet et al. 1989 (Early-Bronze Age, Switzerland); Van Zeist 1968 (Roman, Netherlands) 


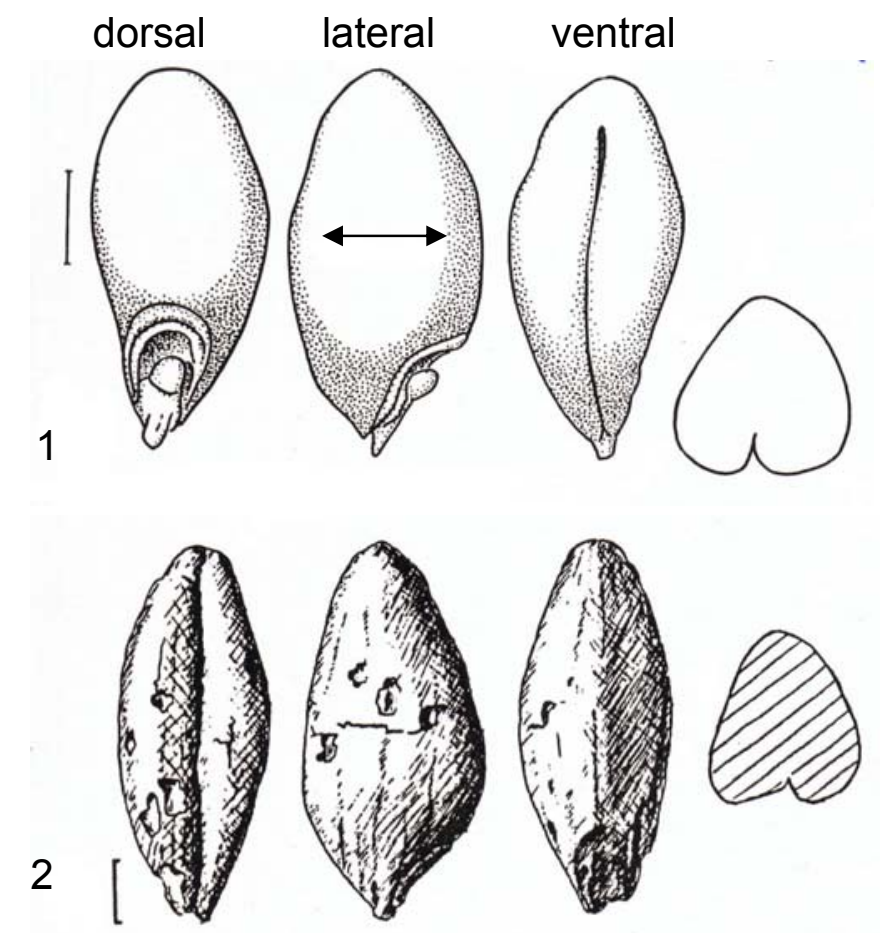

\section{2-grained einkorn}
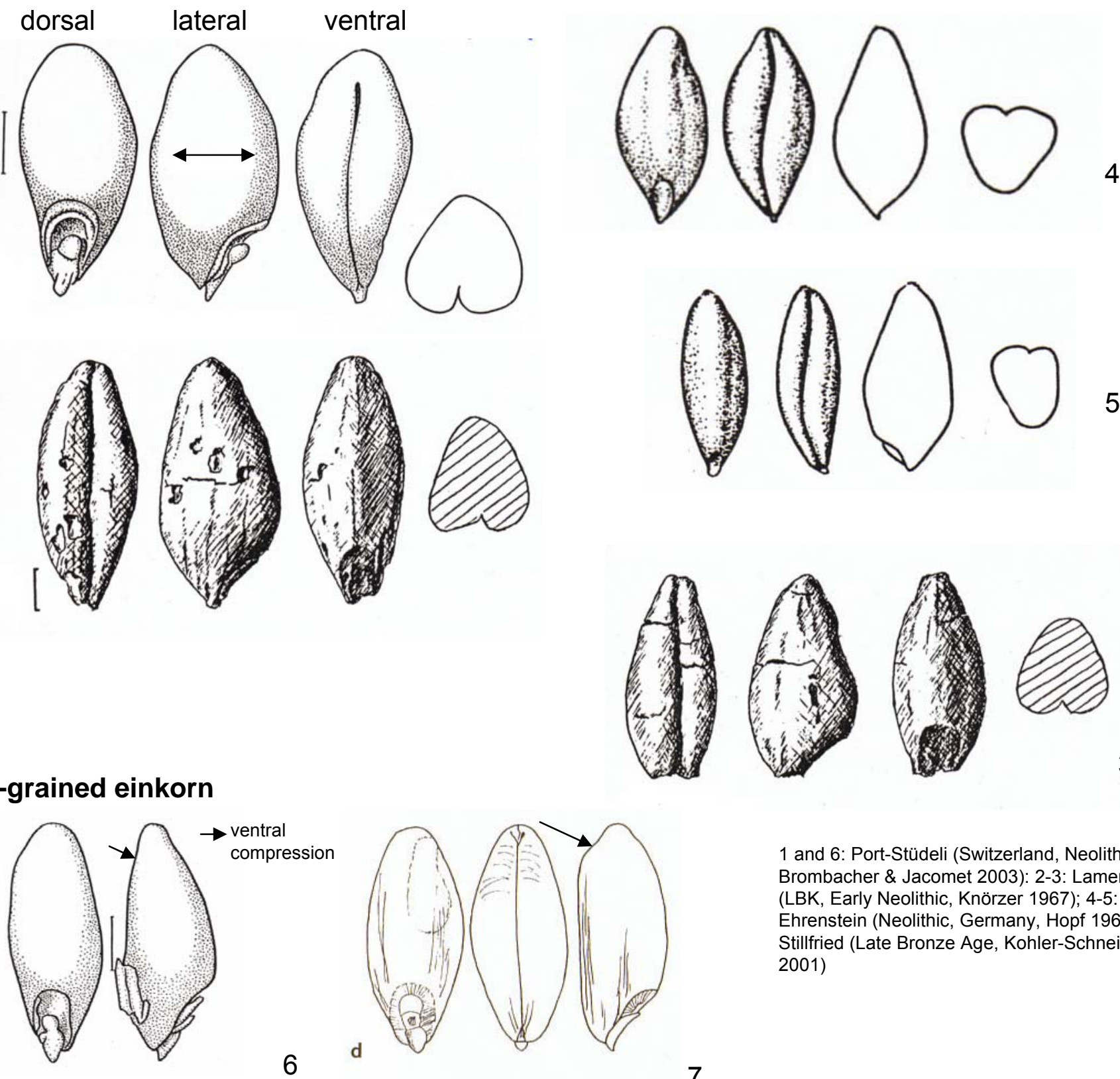

1 and 6: Port-Stüdeli (Switzerland, Neolithic; Brombacher \& Jacomet 2003): 2-3: Lamersdrof (LBK, Early Neolithic, Knörzer 1967); 4-5: Ehrenstein (Neolithic, Germany, Hopf 1968); 7 : Stillfried (Late Bronze Age, Kohler-Schneider 2001)

Shape in plan (seen from the dorsal side); slim, fairly pointed at the ends.

Shape in side view: high backed, more or less equally rounded on each side. Ventral outline likewise convex. Highest part of the grain usually in the middle. Exception: 2-grained einkorn with flat ventral surface.

In transversal section: not evenly rounded, sometimes apparently with "corners". Dorsal side often almost roof-shaped, however with the highest part rounded off. The sides slightly convex, often also slightly concave. The transition from dorsal to ventral side is often marked with a corner. The ventral furrow is narrow and deep (pressed together).

Positioning of the embryo: slanting/upright (not in a cavity!)

Outer surface structure: often there are two longitudinal furrows on the dorsal side to the left and right of the highest part. These are glume impressions.

Characteristic dimensions and ratios:

L: $4.5-7.1 \mathrm{~mm} / \mathrm{B}: 1.0-3.0 \mathrm{~mm}$ (rarely $>2.5 \mathrm{~mm}$ )

$\mathrm{H}: 1.6-3.1 \mathrm{~mm}$ (rarely $<2.3 \mathrm{~mm}$ )

L/B: $1.6-2.58$ (rarely $<2$, mostly more)

$\mathrm{L} / \mathrm{H}: 1.77-2.5$ (rarely $<2$ )

B/H: 0.69-1.2 (mostly <1)

B/Lx100: 37.8-46.2 (<50) difference from emmer!

Variations, identification difficulties:

"Typical" examples of normal, single-grained einkorn have an unmistakeable shape compared with other wheat grains found in central European prehistory. Grains from 2-grained einkorn are more difficult: here there can be similarities with emmer grains. Grains of 2-grained einkorn are much more delicate than those of emmer, and have often a ventral compression ending well short of the apex (esp. the upper grain of each pair). Therefore, they can be identified with \pm great certainty, particularly when chaff is also preserved in the sample. For more details of 2 -grained einkorn see the publication of Kreuz \& Boenke 2003. 


\section{Characters and images of (pre)historical finds of emmer (Triticum dicoccum): grains}
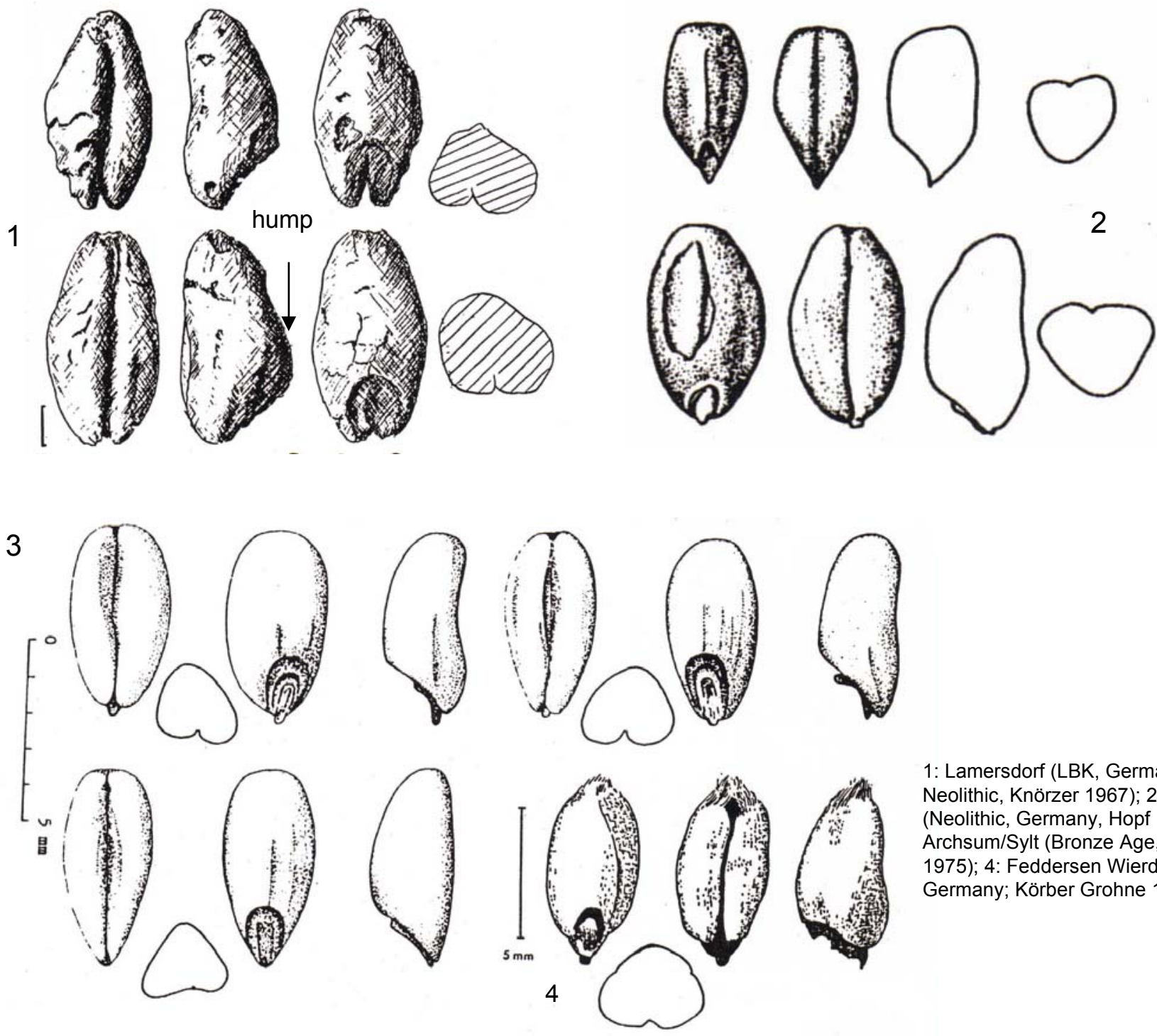

1: Lamersdorf (LBK, Germany, Early Neolithic, Knörzer 1967); 2: Ehrenstein (Neolithic, Germany, Hopf 1968); 3: Archsum/Sylt (Bronze Age, Germany, Kroll 1975); 4: Feddersen Wierde (Iron Age; Germany; Körber Grohne 1967)

Shape in plan view (seen from the dorsal side):

Mostly slim, the upper end frequently rather pointed, but often bluntly rounded too; this last goes particularly for the abundantly found drop-shaped grains. At the lower (embryo) end, most grains are pointed.

Shape in side view:

The dorsal outline is often hump-backed; the highest point is often directly above the embryo. The embryo-cavity is often not symmetrically rounded, but twisted. The ventral side is mostly lightly concave to flat.

Shape in section:

Fairly evenly rounded to rather angular; the ventral furrow is narrow and deep (rarely also angled transverse section)

Positioning of the embryo: mostly slanting-upright.

Various surface structures:

Similar to einkorn, and well-preserved examples have visible longitudinal furrows which represent impressions of the glumes.

Characteristic measurements and ratios:

$\mathrm{L}: 3.5-6.1 \mathrm{~mm}$

B: $1.8-3.2 \mathrm{~mm}$ (rarely $>3 \mathrm{~mm}$, normally less)

$\mathrm{H}: 1.5-3.4 \mathrm{~mm}$

L/B: 1.57-2.04 (mostly around 2)(difference from einkorn!)

L/H 1.57-2.5 (mostly >2 but rarely as much as 2.5: difference from einkorn and spelt).

B/Lx100: 48.33 - 60.38 (normally around 54) (difference from einkorn).

Possibilities for confusion, identification difficulties:

Delicate grains, for example from the apical part of an ear can be confused with those of 2-grained einkorn.

Grains from one-grained spikelets (from the base and the top of an ear) look very similar to "normal" (1-grained) einkorn.

Differentiation from normal einkorn: emmer grains are wider in relation to their height, that is their $\mathrm{B} / \mathrm{H}$ ratio is usually $>1$.

Differentiation from naked wheat forms: Grains of emmer are normally narrower (mostly $<3 \mathrm{~mm}$ wide). From this their L/ B ratio is always distinctly higher (around 2) than in naked wheat, e.g. Triticum aestivum $(<1.7)$.

Separation from spelt: Emmer grains are on average higher than those of spelt, so the L/H ratio in emmer is 1.9-2.5 (mostly around 2.3), while it is mostly $>2.5$ in Triticum spelta. Furthermore, spelt grains, particularly when they were charred in the spikelets, can have a very similar shape (see Jacomet et al. 1988, Eptingen-Riedfluh, also Jacomet \& Dalnoki 2002). 

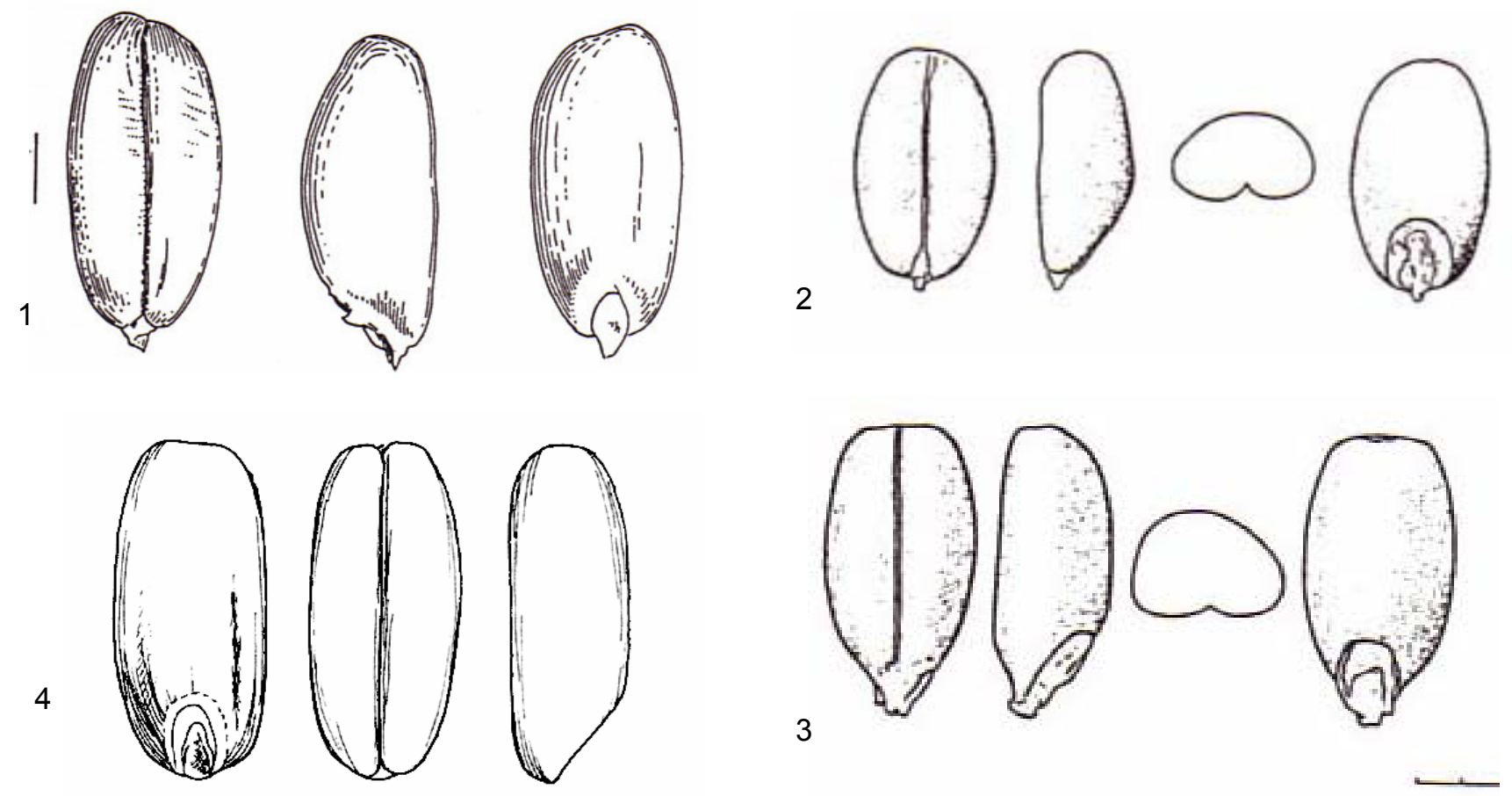

$\boldsymbol{d}$
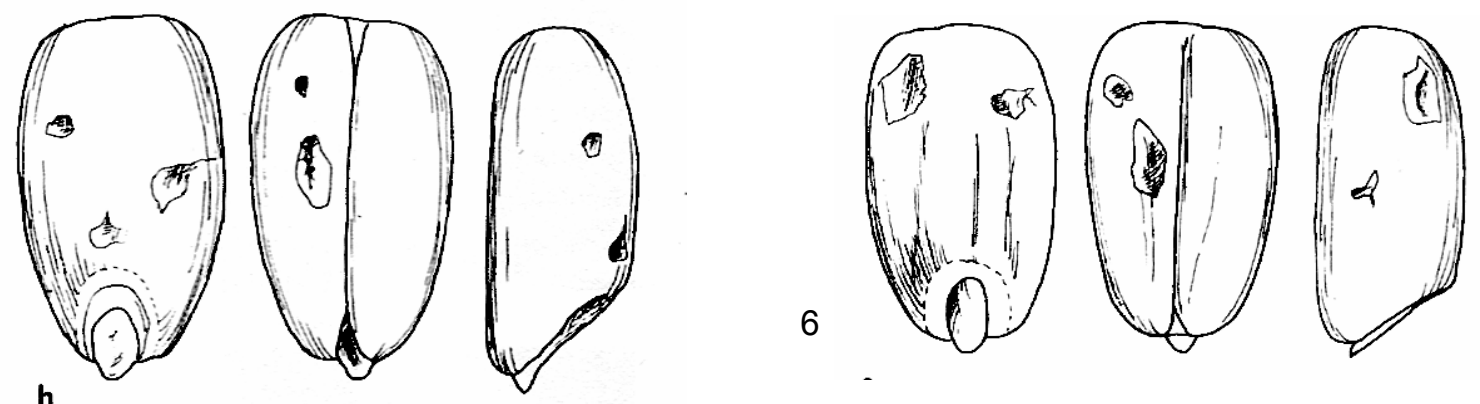

1: Zürich-Mozartstrasse (Early Bronze Age, Switzerland, Jacomet et al. 1989); 2-3+7: Valkenburg (Roman, Netherlands, Van Zeist 1968); 4-6: Stillfried (Late Bronze Age, Austria, Kohler-Schneider 2001)

!!! oops!!! grains of the so-called « new glume wheat » may look similar, however somewhat more delicate; see later pages

Shape in plan view (dorsal view):

"typical" grains: oval, often with almost parallel sides. The upper end bluntly rounded, lower end blunt but often relatively pointed. There may be many grains which are somewhat drop-shaped (see figures).

Shape in side view:

Dorsal ridge symmetrically rounded, but very flat (also the drop-shaped spelt grains are rather flat compared with emmer, but higher than the "typical" ones). Ventral surface mostly almost flat.

Shape in section:

Mostly symmetrically rounded. Ventral furrow narrow and deep.

Characteristic measurements and ratios:

$\mathrm{L}:$ 4.7-8.4 mm

B: $2.0-4.1 \mathrm{~mm}$

$\mathrm{H}: 1.7-3.3 \mathrm{~mm}$ (rarely $>3 \mathrm{~mm}$ )

L/B: $1.5-2.45$

L/H: 2.1-3.09 (in "typical" grains $>2.5$ )

$\mathrm{B} / \mathrm{H}: 1.0-1.5$

Possibilities for confusion:

See under emmer. Important: when spelt grains became charred while in the ear or spikelet, their shape is quite different from that described in the literature as "typical" spelt. It approaches emmer closely in shape and size ratios, and drop shaped grains are encountered regularly. 
Characters and images of (pre)historical finds of naked wheat: grains

1
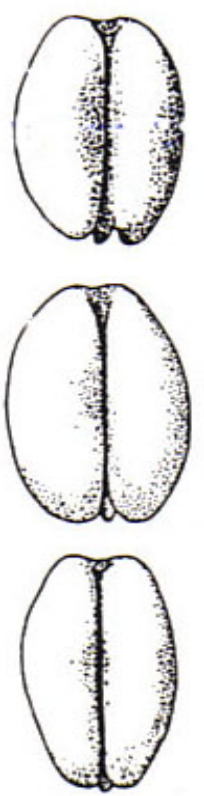
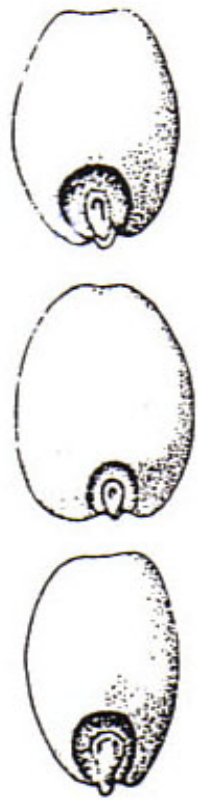
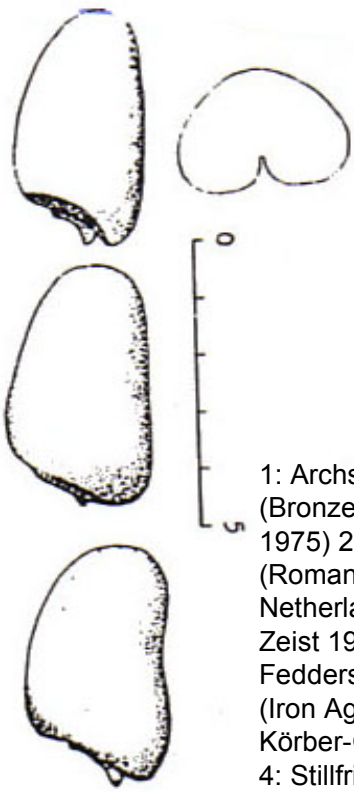
(Roman,

2
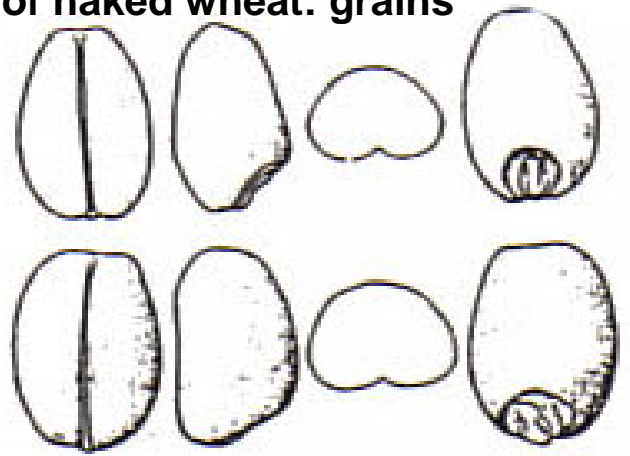

1: Archsym/Sylt (Bronze Age; Kroll 1975) 2: Valkenburg Netherlands, Van Zeist 1968); 3; Feddersen Wierde (Iron Age, Germany, Körber-Grohne 1967; 4: Stillfried (Late Bronze Age, Austria, Kohler-Schneider
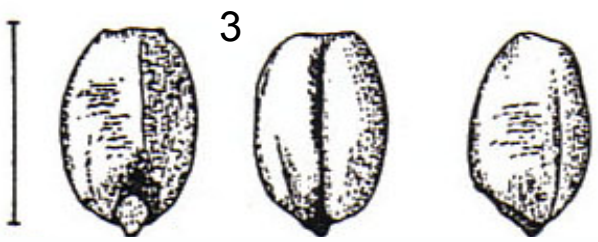
2001)
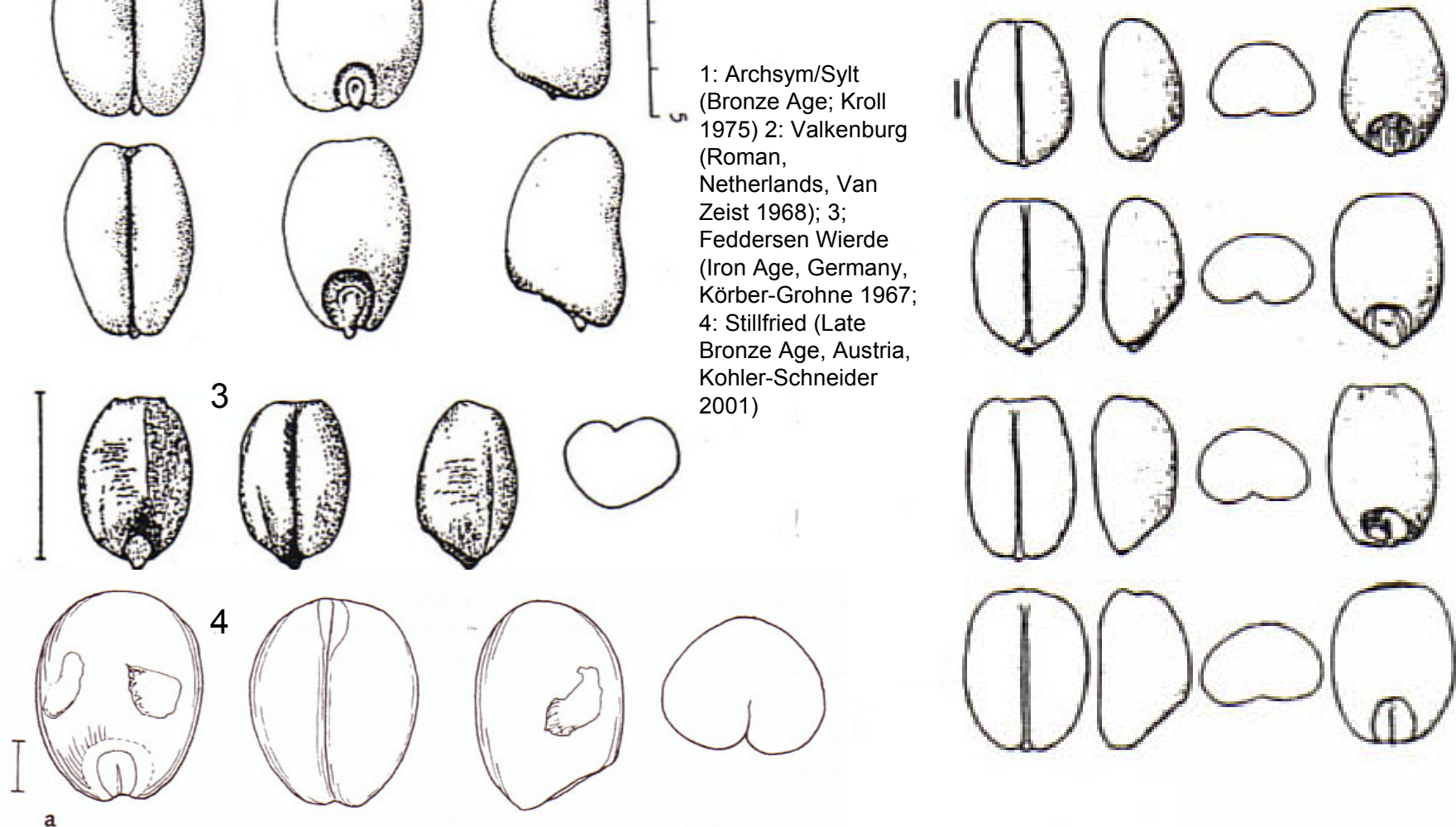

In the following we don't go into the details of the distinction between tetra- and hexaploid naked wheats (some information on the problematic is given on the following page). For those interested see Kislev 1979 and 1984; some of Kislev's observations are added below. The distinction is (at least) difficult (if not impossible).

In the following, by Triticum aestivum s.I. we mean all hexaploid naked wheat varieties (incl. T. cpmpactum), by T. turgidum s.I. we mean tetraploid naked wheat in general (T. turgidum or T. durum). We don't treat here other hexa- or tatraploid naked wheat types because they seem not to play any role in central European (pre)history. For an overview of the taxa see the tables at the beginning of part 2.

We also don't put too much attention to the distinction of the different bread wheat-species (or more likelely: varieties), because the forms and measurements are overlapping, and - in addition - the ploidy-level is per se not known.

Shape in plan view (dorsal view):

Slender ("tetraploids") to oval ("T. aestivum-vulgare") to round ("T.compactum"). The upper end bluntly rounded (rarely also pointed: cf tetraploid), lower end blunt-rounded, too. Drop-shaped grains possible (cf tetraploid). The surface is smooth, without furrows. The germ area is deep, the embryo lies like in a cavity.

Shape in side view:

Dorsal ridge (mostly symmetrically) rounded, in tetraploids humpy. Ventral surface from rounded (convex) to flat. Max. height ca. in the middle.

Shape in section:

Mostly symmetrically rounded. Ventral furrow wide and deep.

Characteristic measurements and ratios:

L: 3,4-7,0 mm / B: 2,2-4,7 mm / H: 2,0-4,0 mm

L/B: 1.07-1,73 (the boundary between "T. compactum" and "T. vulgare" is seen around 1,5 (compactum is below, vulgare above)

$\mathrm{L} / \mathrm{H}: 1,1,-2,1$

$\mathrm{B} / \mathrm{H}: 1.1-1,3$

B/L*100: 54.4-89,3 (“T. compactum" >65-70, "T. vulgare" <65)

Separation of naked wheat grains from other wheat species (Table 9):

Separation from emmer (Triticum dicoccum):

Grains of emmer are mostly distinctly narrower (usually $<3 \mathrm{~mm}$ wide). Consequently their L/B ratio is clearly higher than in naked wheats (mostly around 2). There are also clear differences in B/L x 100 ratio, which is between 48 and 60 for emmer (average usually around 54 ) also distinctly lower than in naked wheats (around 54-81).

Separation from "typical" (flat) spelt grains (Triticum spelta):

"Typical" spelt grains are relatively long and fairly slim; their L/B ratio is around $2(1.5-2.45)$. Otherwise they are much flatter than naked wheat grains, so their $\mathrm{L} / \mathrm{H}$ ratio is certainly $>2$. mostly $>2.5$, while in naked wheat it is between $1.1-2.1$. 
Critical remarks to the identification possibilities of (pre)historical finds of naked wheat: grains

In the literature of central Europe all naked wheat grains were formerly considered to be hexaploids (Triticum aestivum L., bread wheats in the widest sense). The author, through the study of beautifully preserved finds of naked wheat from lake shore settlements in the sub-Alpine region, became aware that this clearcut arrangement could not be quite so certain (Jacomet \& Schlichtherle 1984). Heer had already (1865) recognised the morphologically distinct character of some of the lake-settlement wheats and described these as a separate subspecies, called Triticum vulgare antiquorum ("small lake settlement wheat"). Our conclusion, and also Heer's before as well as that of U. Maier (1996) later, depend mainly on morphological characters of the rachis and glumes (see below). Lastly, distinct similarities with tetraploid naked wheats of the Triticum turgidum-group can be recognised. Also, Kislev (1979 and 1984) has referred to the possible presence of tetraploid naked wheats in the archaeological finds from the near East; he described what was in his opinion a tetraploid find as a new hitherto unknown species (Triticum parvicoccum). The author was therefore interested in which grain characters the tetraploid naked wheats could be separated from the hexaploids (characters see previous page, from Kislev 1984). From that, it appears that the grains of naked tetraploid wheats have a greater similarity to emmer (tetraploid glume wheat) than to hexaploid bread wheats. This however, does not hold for the larger part of the clearly tetraploid "lake-dwelling-wheats", and maybe also not for other finds of that type from other geographical regions and periods which were made in the meantime (e.g. Kühn 1996, PetrucciBavaud \& Jacomet 2002; Moffett 1991). Therefore we propose to identify naked-wheat grains in central European contexts as "Triticum "nudum", what means, that it is a tetra- or hexaploid naked wheat (so T. aestivum s.l./turgidum s.l. (incl. durum's; it hast always to be specified which nomenclature is used)).

An other critical point is the difficulty to make a differentiation between the different forms of hexaploid naked wheats. From the older literature - in a time, when everybody supposed that all naked wheat found in Europe was a hexaploid - a huge debate concerning the separation of dense-eared forms (cone wheat, Triticum aestivum grex aestivocompactum Schiem.) and lax-eared forms (Triticum aestivum L. s. str.) is known. Hopf (various publications), van Zeist 1968, Rothmaler 1955 and many others besides give various characters and dimensions as identification criteria (see partly on the previous page). This became obsolete since it is known that also tetraploids can be present in the archaeological material.

Nevertheess, it may be important to note during identifying archaeological naked wheat remains the form of the grains, because it is not excluded that different varieties are present. One can e.g. distinguish between:

- short stubby grains (former T. compactum type)

- long slim grains (former $\underline{T}$. vulgare type)

- intermediate shapes 
The principal diagnostic features of a stylized spikelet of a glume wheat

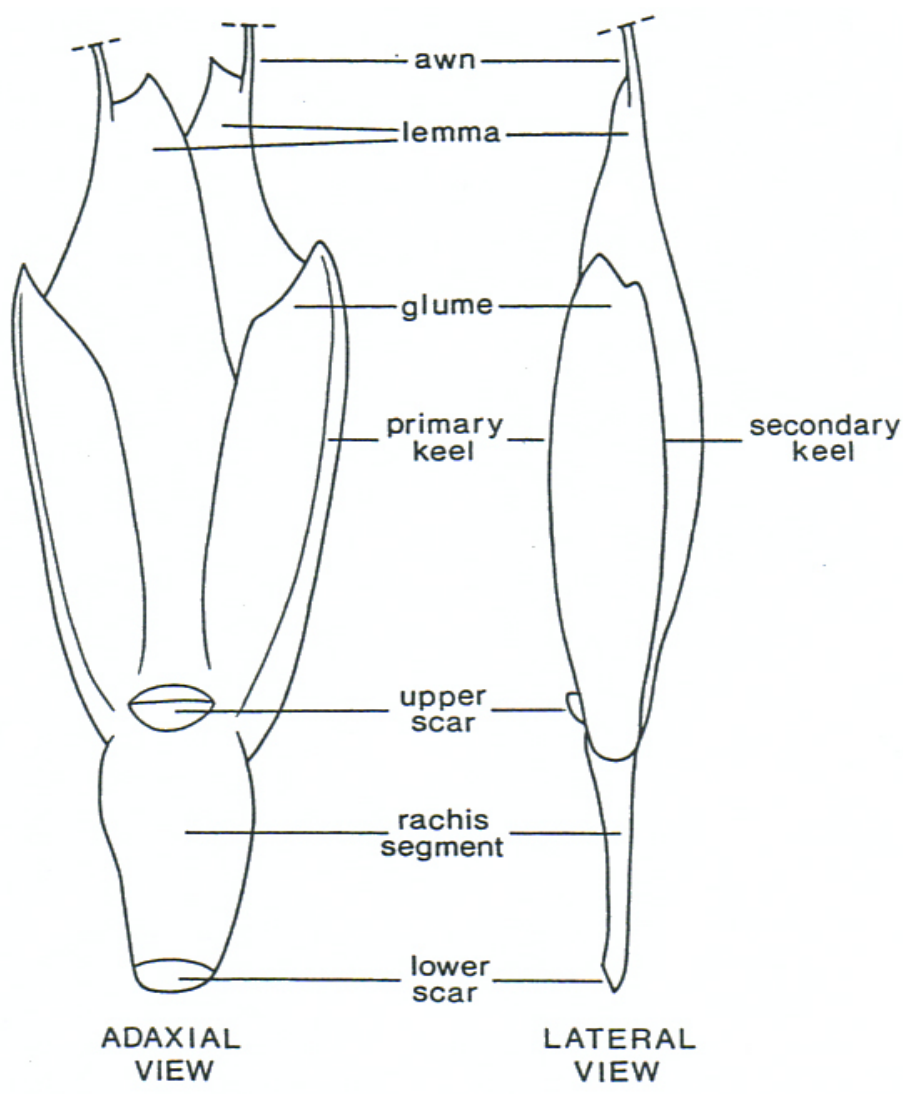

Hillman et al. 1996
The by- products resulting from grain processing, such as chaff, provide the most important means for the identification of prehistoric wheat species on the basis of morphology (see Fg. 2 in Hillman 1984). These are rachis parts (internodes. rachis fragments) and the glumes (also lemmas and paleas). These parts of the cereal flowering structure provide many diagnostically useful features for the separation of the individual taxa.

The separation of the individual species, is firstly based on morphological characters. Secondly, measurements are used for identification. The characters used in the following section come partly from the literature (Helbaek 1952 a\&b, van Zeist 1968, Hopf 1968, Villaret-von Rochow 1967, Körber-Grohne 1967 and Körber-Grohne and Piening 1983, Hillman et al. 1996, Jones et al. 2000, Kohler-Schneider 2001), partly they were worked out by the Basel Lab members (e.g. Zibulski 2001) on the basis of recent and subfossil material.

For identification, the following morphological criteria should be considered (after Jones et al. 2000):

- the upper scar (scar left by the disarticulation of rachis)

- the primary keel (the level at which it arises, his ascendence)

- the secondray keel (robust or not)

- the angle of glume insertion

- the width of the glume bases in lateral view

- the veini

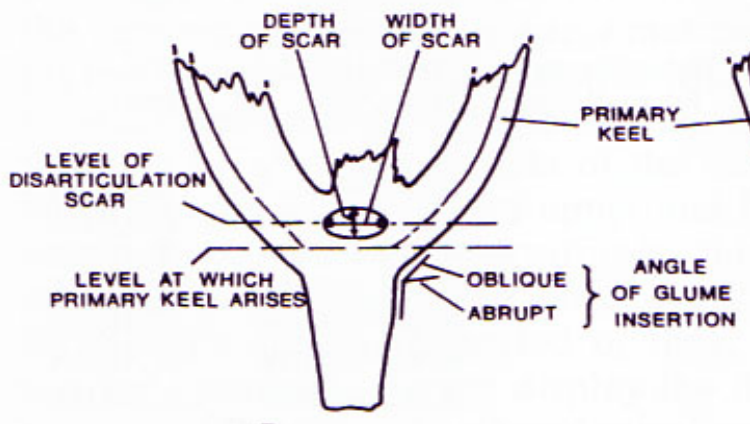

ABAXIAL
LATERAL

Fig. 5. A diagram indicating some of the terms used to describe spikelet bases in the text Jones et al. 2000

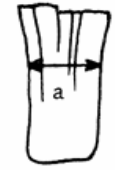

Hüllspelzenbasis

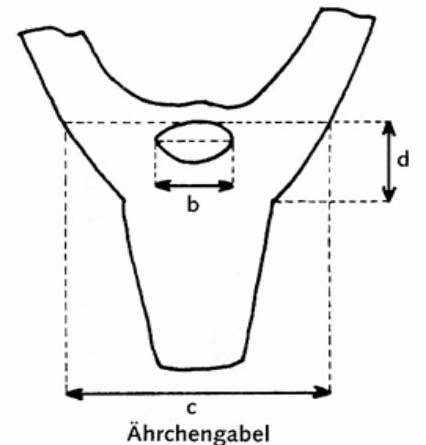

measurements used for the distinction of glumewheat chaff:

a width uf the glume bse in lateral view

$b$ width of the upper scar

c width of the spikelet fork at the upper margin of the upper scar

d distance between upper scar and the point of glume insertion 
glume wheat chaff: morphological and metrical criteria for distinguishing of rachis remains, spikelet forks and glumes bases of glume wheat: einkorn-emmer and spelt.

Measurement lines see other pages

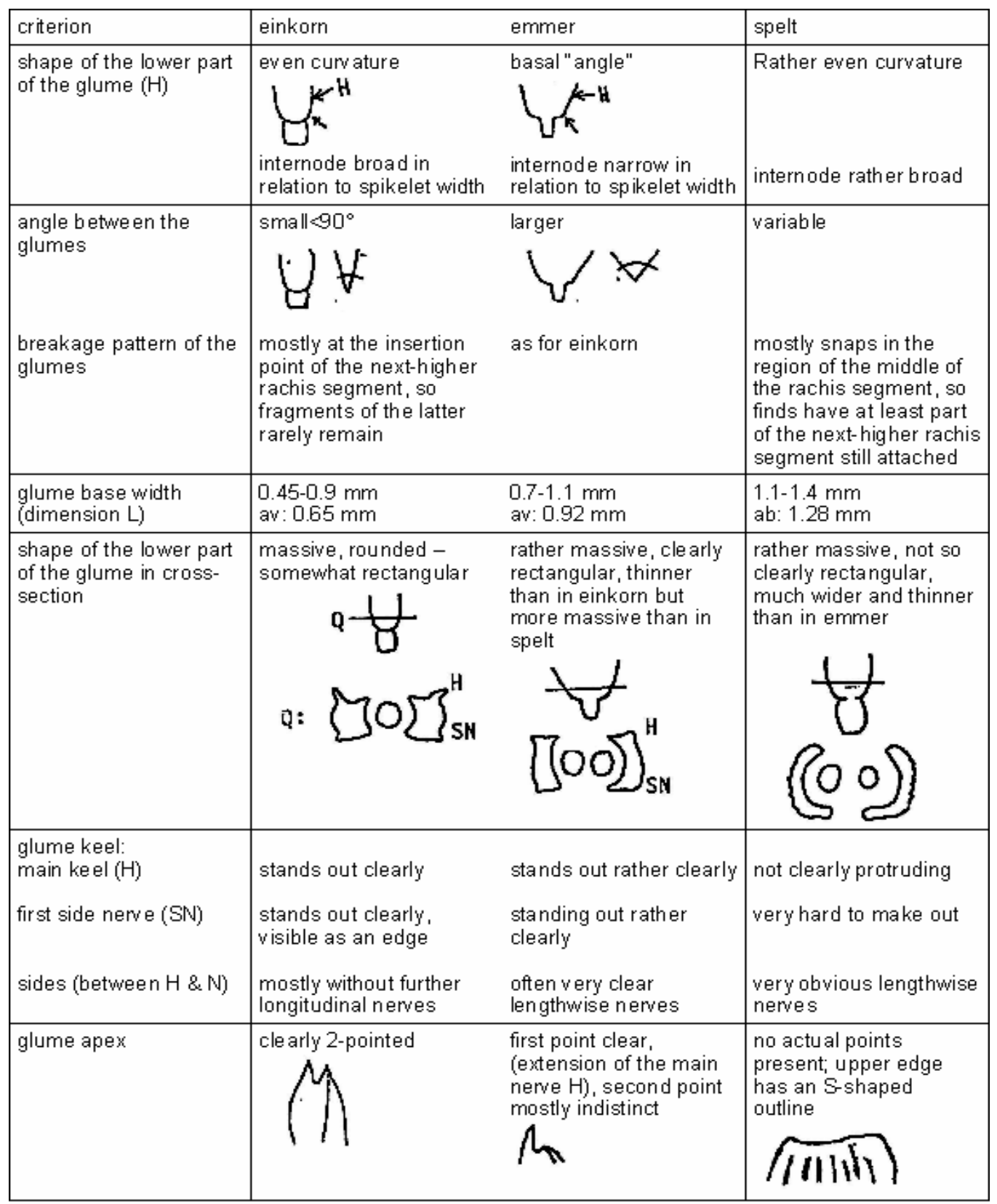

composed after: Helbaek 1952A + B, Körber-Grohne 1967, Körber-Grohne \& Piening 1983, van Zeist 1968, Villaret-von Rochow 1967 and own studies. Composed by: S. Jacomet. From Jacomet / Brombacher / Dick 1989.

For highly fragmented remains of glume wheat chaff see the work of Zibulski 2001

The following suggest themselves as particularly important measurement points that are diagnostic for species identification (for measurement lines see other pages)

- the basal width of the glumes between the keel and the first side nerve $(L)$ : provides good identification criteria between the species although there is a certain amount of overlap between emmer and einkorn on the one hand, and between emmer and spelt on the other.

- the basal width of the spikelet $(Q)$

- the maximal width of the rachis $(P)$

- the ratio $Q: P$. In emmer this is around 2:1, in einkorn normally $<1.5: 1$.

- the maximal width of the spikelet $(R)$ 
Morphological and metrical criteria for the distiction of rachis remains, spikelet forks and glumes bases of glume wheat: EINKORN AND EMMER

For english terms see pages 26 and 30 !
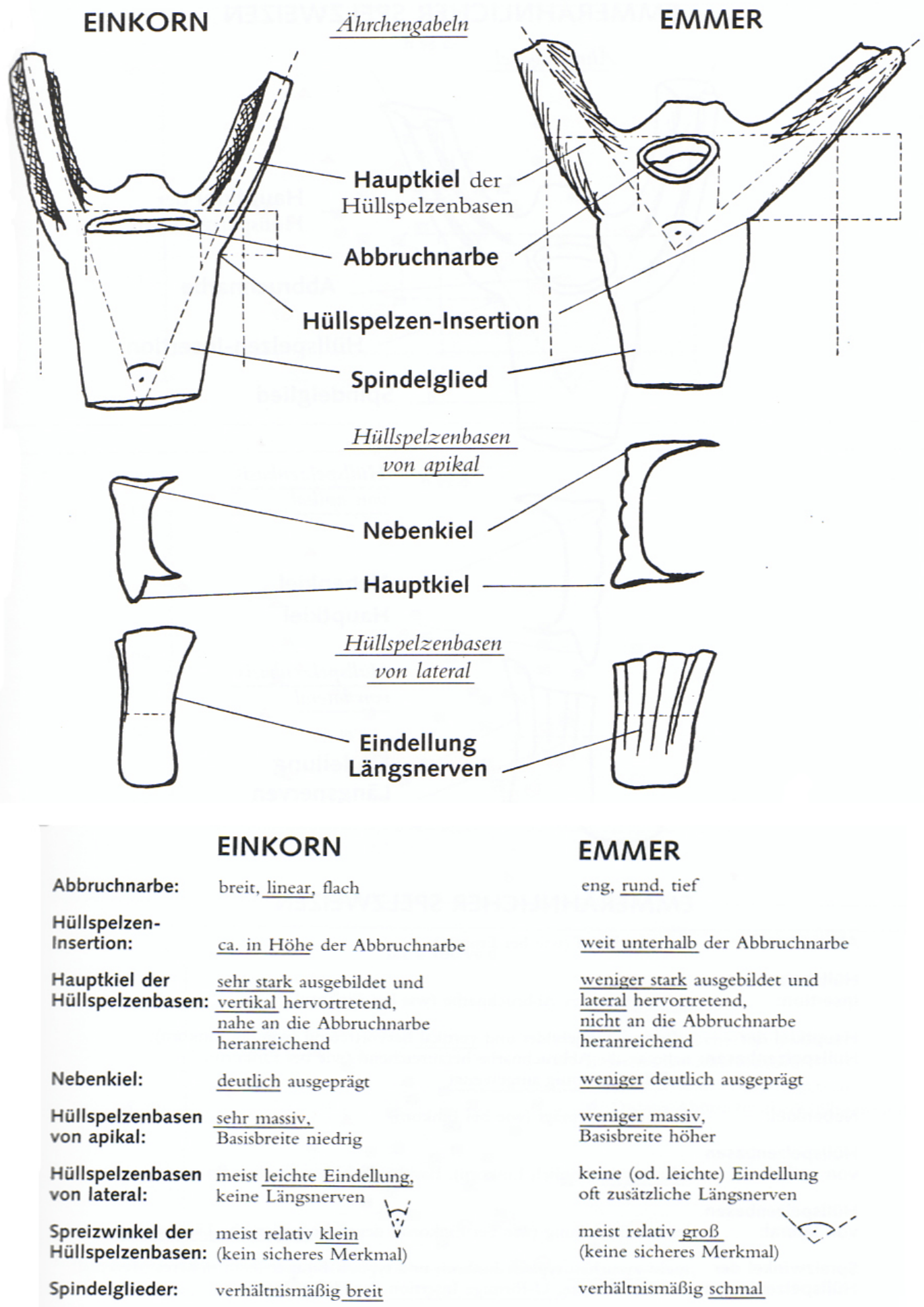

\begin{tabular}{|c|c|}
\hline Abbruchnarbe: & breit, linear, flach \\
\hline $\begin{array}{l}\text { Hüllspelzen- } \\
\text { Insertion: }\end{array}$ & ca. in Höhe der Abbruchnarbe \\
\hline $\begin{array}{l}\text { Hauptkiel der } \\
\text { Hüllspelzenbasen: }\end{array}$ & $\begin{array}{l}\text { sehr stark ausgebildet und } \\
\text { vertikal hervortretend, } \\
\text { nahe an die Abbruchnarbe } \\
\text { heranreichend }\end{array}$ \\
\hline Nebenkiel: & $\underline{\text { deutlich ausgeprägt }}$ \\
\hline $\begin{array}{l}\text { Hüllspelzenbasen } \\
\text { von apikal: }\end{array}$ & $\frac{\text { sehr massiv, }}{\text { Basisbreite niedrig }}$ \\
\hline $\begin{array}{l}\text { Hüllspelzenbasen } \\
\text { von lateral: }\end{array}$ & $\begin{array}{l}\text { meist leichte Eindellung, } \\
\text { keine Längsnerven }\end{array}$ \\
\hline $\begin{array}{l}\text { Spreizwinkel der } \\
\text { Hüllspelzenbasen: }\end{array}$ & $\begin{array}{l}\text { meist relativ klein } \\
\text { (kein sicheres Merkmal) }\end{array}$ \\
\hline Spindelglieder: & verhältnismäßig breit \\
\hline
\end{tabular}

\section{EMMER}

eng, rund, tief

weit unterhalb der Abbruchnarbe

weniger stark ausgebildet und lateral hervortretend,

nicht an die Abbruchnarbe heranreichend

weniger deutlich ausgeprägt

weniger massiv,

Basisbreite höher

keine (od. leichte) Eindellung oft zusätzliche Längsnerven

meist relativ gro $\beta$<smiles>CC1CC1C</smiles>

(keine sicheres Merkmal)

verhältnismäßig schmal

Abb. 28: Bestimmungsmerkmale an Ährchengabeln von Einkorn und Emmer (schematisch). 
Morphological and metrical criteria for the distiction of rachis remains, spikelet forks and glumes bases of glume wheat: new glume wheat

For english terms see pages 26 and 30 !

\title{
EMMERÄHNLICHER SPELZWEIZEN
}

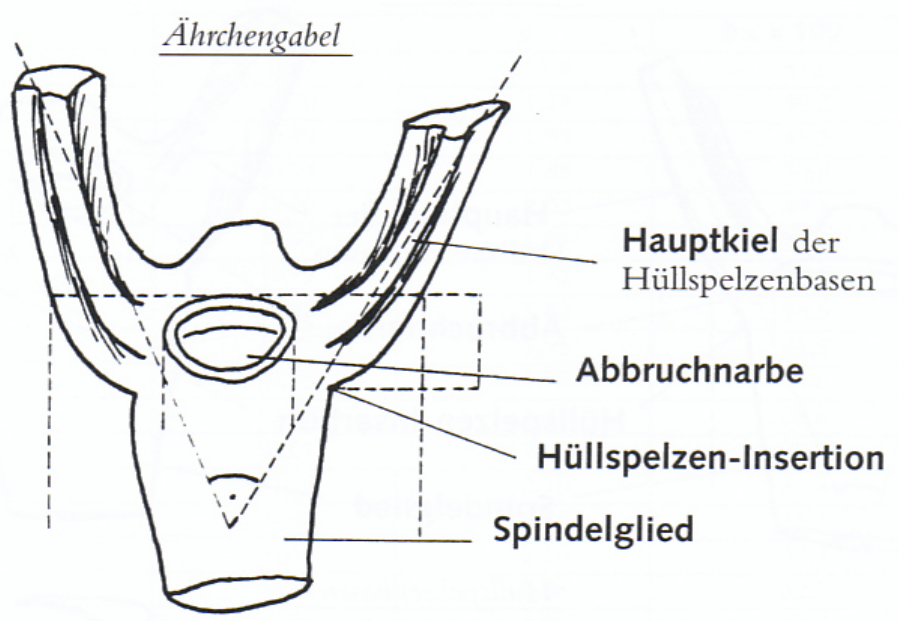

Hüllspelzenbasis von apikal

Nebenkiel Hauptkiel

Hüllspelzenbasis von lateral

Eindellung Längsnerven

\section{EMMERÄHNLICHER SPELZWEIZEN}

\begin{abstract}
Abbruchnarbe: eng, rund, tief (wie bei Emmer)
HüllspelzenInsertion: ca. in Höhe der Abbruchnarbe (wie bei Einkorn)

Hauptkiel der sehr stark ausgebildet und vertikal hervortretend (wie bei Einkorn), Hüllspelzenbasen: nahe an die Abbruchnarbe heranreichend (wie bei Einkorn), auffällig U-förmig ausgeweitet

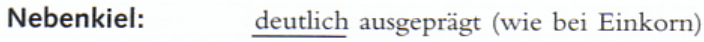

Hüllspelzenbasen von apikal:

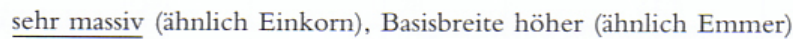

Hüllspelzenbasen von lateral:

leichte Eindellung (wie bei Einkorn), deutliche zusätzliche Längsnerven

Spreizwinkel der meist zwischen typisch Einkorn und typisch Emmer (kein sicheres Merkma Hüllspelzenbasen: auffällig abrupte, U-förmige Insertion der Hüllspelzenbasen

Spindelglieder: verhältnismäßig schmal (eher wie bei Emmer)

Abb. 29: Bestimmungsmerkmale an Ährchengabeln von „emmerähnlichem Spelzweizen“ (schematisch).
\end{abstract}

Tab. 53: Meßwerte von Einkorn $(n=10)$, Emmer $(n=10)$ und ,emmerähnlichem Spelzweizen" $(n=30)$ in mm.

\begin{tabular}{|l|l|c|c|c|}
\hline & & Einkorn & Emmer & $\begin{array}{c}\text { Emmerähnlicher } \\
\text { Spelzweizen }\end{array}$ \\
\hline a & Basisbreite der Hüllspelzen & $0,66(0,5-0,8)$ & $0,9(0,7-1,0)$ & $0,91(0,8-1,1)$ \\
\hline b & Breite der Abbruchnarbe & $0,87(0,7-1,0)$ & $0,70(0,6-0,8)$ & $0,85(0,7-1,0)$ \\
\hline c & Basisbreite der Ährchengabeln & $1,84(1,7-2,0)$ & $2,21(2,0-2,5)$ & $2,12(1,8-2,4)$ \\
\hline d & Distanz Abbruchnarbe/Hüllsp.insertion & $0,59(0,5-0,7)$ & $0,90(0,7-1,1)$ & $0,74(0,5-0,9)$ \\
\hline b/c $\times 100$ & Index & $47,2(40,2-51,6)$ & $31,4(27,2-35,3)$ & $40,5(34,5-47,5)$ \\
\hline
\end{tabular}

Measurements of einkorn $(n=10)$, emmer $(n=10)$ and new glume wheat $(n=30)$ chaff, in mm 
Morphological criteria for the distiction of rachis remains, spikelet forks and glumes bases of glume wheat: einkorn, new glume wheat and emmer (from Jones et al 2000)

Table 1. Summary of the characteristics which distinguish the new type glume bases from typical einkorn and emmer glume bases from Greece

\begin{tabular}{|c|c|c|}
\hline Einkorn & New type & Emmer \\
\hline $\begin{array}{l}\text { Scar left by disarticulation of rachis wide } \\
\text { and often shallow }\end{array}$ & $\begin{array}{l}\text { Scar left by disarticulation of rachis wide } \\
\text { and deep }\end{array}$ & Sear left by disarticulation of rachis narrow \\
\hline $\begin{array}{l}\text { Primary keel prominent and projecting. } \\
\text { abaxially }\end{array}$ & As einkorn & $\begin{array}{l}\text { Primary keel usually less prominent and } \\
\text { tending to project laterally }\end{array}$ \\
\hline $\begin{array}{l}\text { Base of primary kcel arising at the same } \\
\text { level as the attachment scar }\end{array}$ & As einkorn & $\begin{array}{l}\text { Base of primary keel arising below the level } \\
\text { of the attachment scar }\end{array}$ \\
\hline $\begin{array}{l}\text { Primary keel ascends more or less } \\
\text { vertically from scar }\end{array}$ & $\begin{array}{l}\text { Primary kecl extends laterally before } \\
\text { ascending }\end{array}$ & Primary keel ascends obliquely \\
\hline Secondary keel robust but rounded & $\begin{array}{l}\text { Secondary keel sharply angled, often with } \\
\text { a clearly defined 'vein' running along it }\end{array}$ & Secondary keel angled but less prominent \\
\hline $\begin{array}{l}\text { Glumes inserted into the rachis at an } \\
\text { oblique angle }\end{array}$ & $\begin{array}{l}\text { Glumes inserted into rachis at an abrupt } \\
\text { angle }\end{array}$ & $\begin{array}{l}\text { Glumes inserted into the rachis at an oblique } \\
\text { angle }\end{array}$ \\
\hline Glume hases narrow & As cmmer & Glume bases wide \\
\hline $\begin{array}{l}\text { Lateral face of glume bases with little or } \\
\text { no veining near the base }\end{array}$ & As emener & $\begin{array}{l}\text { Lateral face of glume bases usually veined } \\
\text { near the base }\end{array}$ \\
\hline
\end{tabular}

Note that, like ail identification criteria, there is considerable variation within as well as between different types which is not apparent from a summary table (see text for more details)
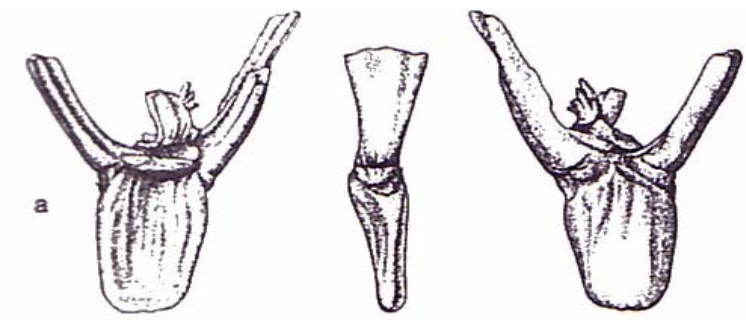

einkorn
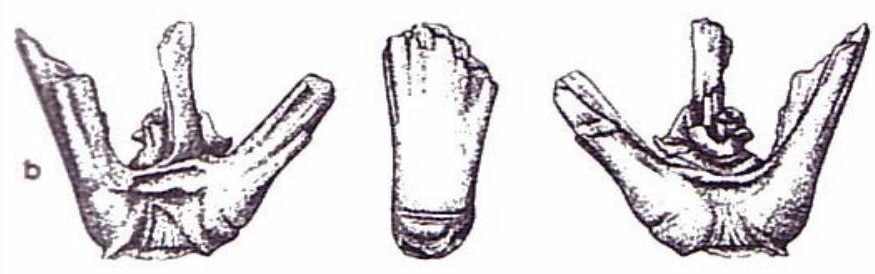

emmer

new glume wheat
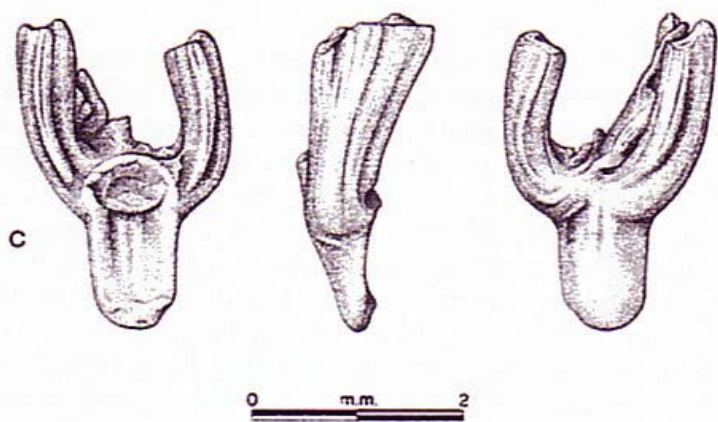
wheat: measurements of einkorn, emmer and new glume wheat chaff: comparison Examples from Late Bronze Age Stillfried, Austria
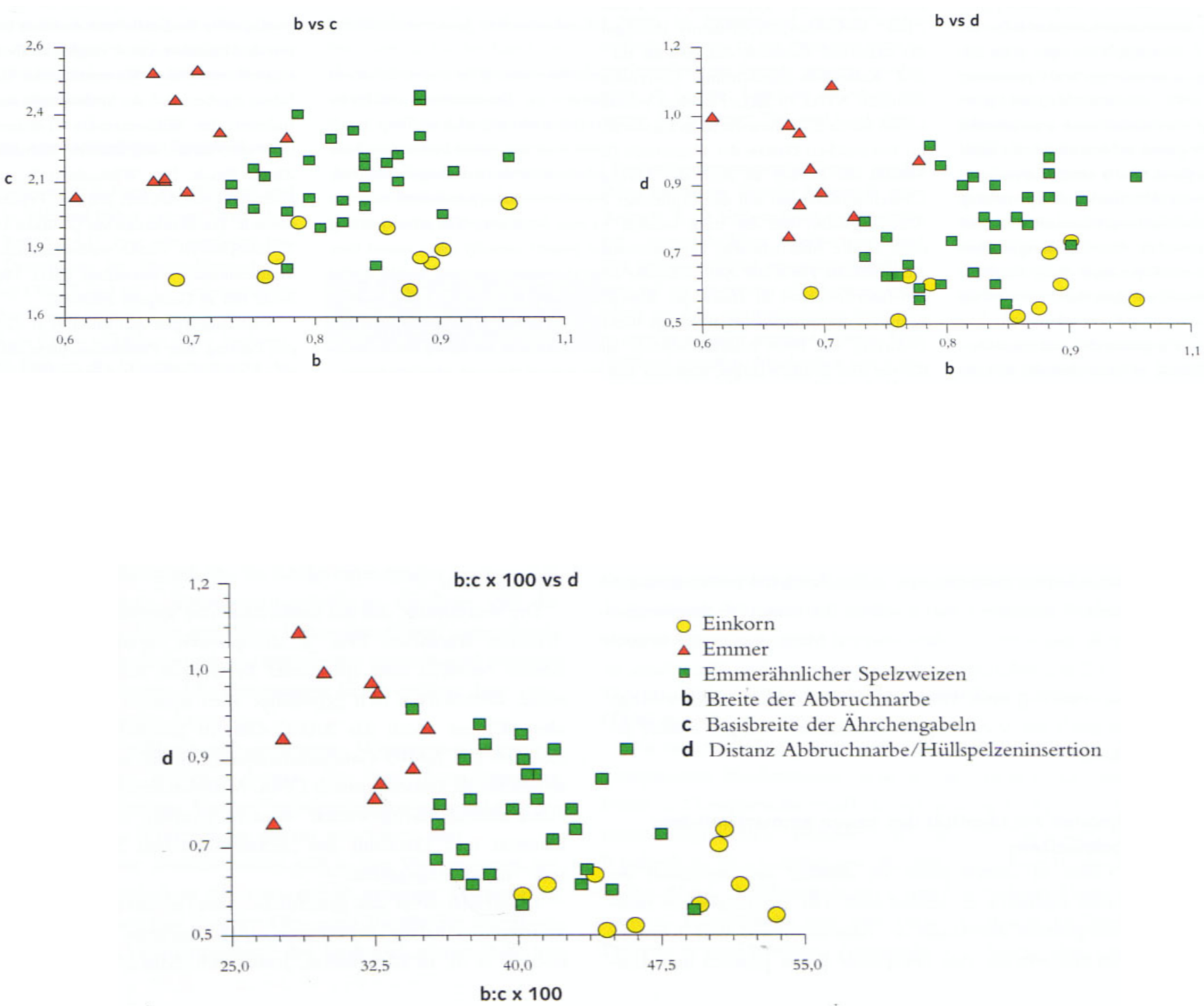

Measurement lines see p. 28 
Images of (pre)historical finds of the new glume wheat (Triticum nn) chaff (spikelet forks) and grains (?)
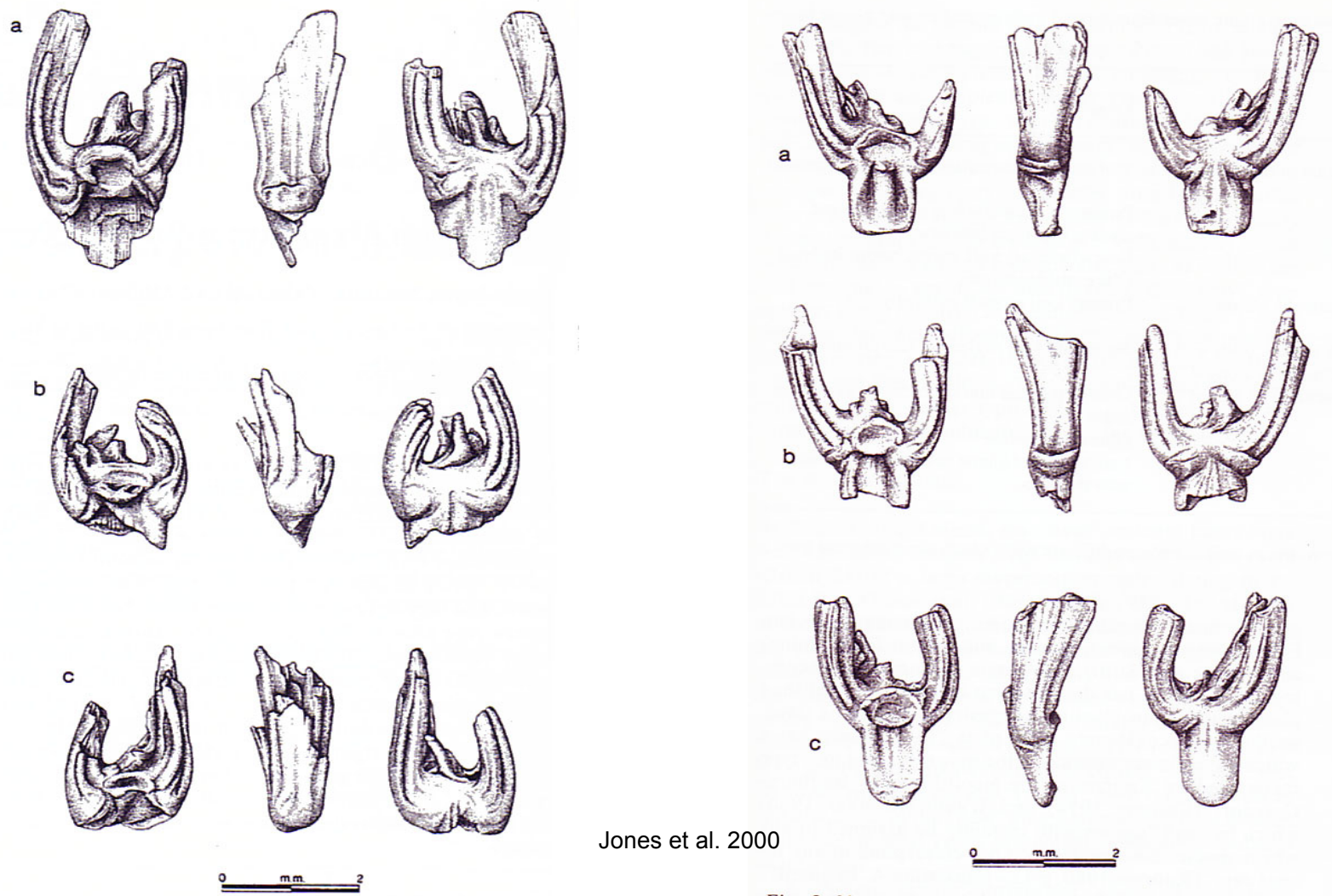

Jones et al. 2000 Fig. 3. New type spikelet bases from Bronze Age Assiros
Toumba: a and b sample 4650 , $\mathbf{c}$ sample 4384

Fig. 2. New type spikelet bases from the Neolithic sites: a and b
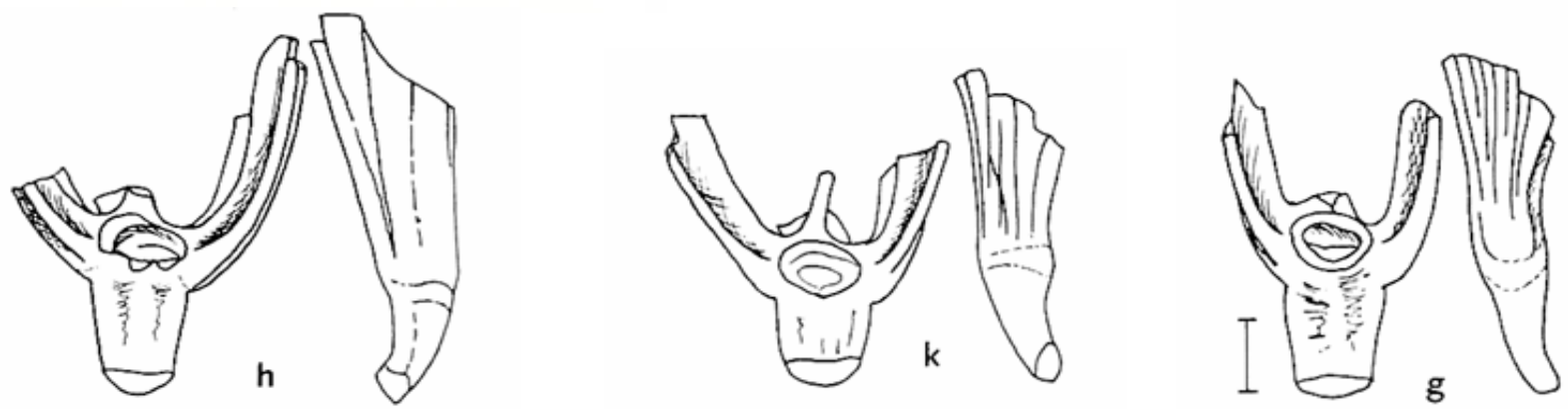

Kohler-Schneider 2001: Stillfried, Austria, Late Bronze Age

possible corresponding modern species
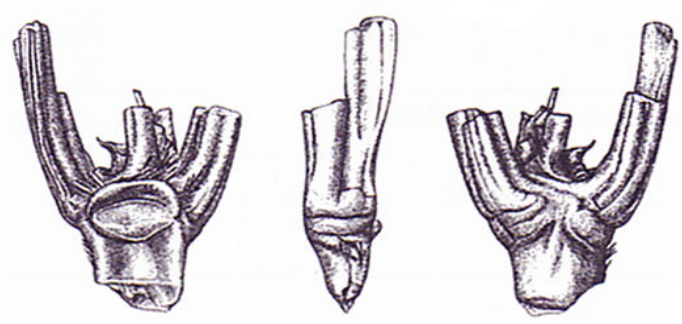

Fig. 6. A modern charred spikelet base of Triticum timopheevi

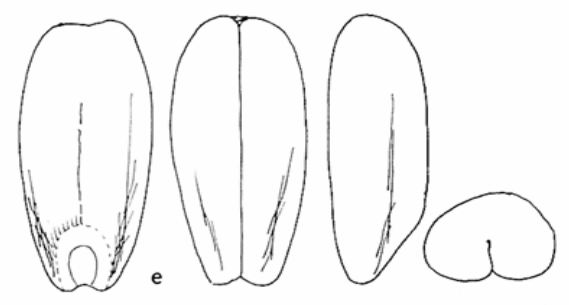

maybe the

corresponding grains....
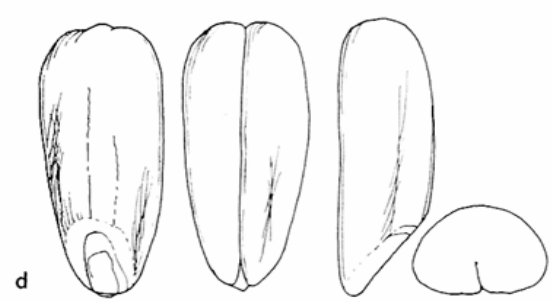

(from Stillfried) 


\section{spikelets}

\section{spikelets and chaff}
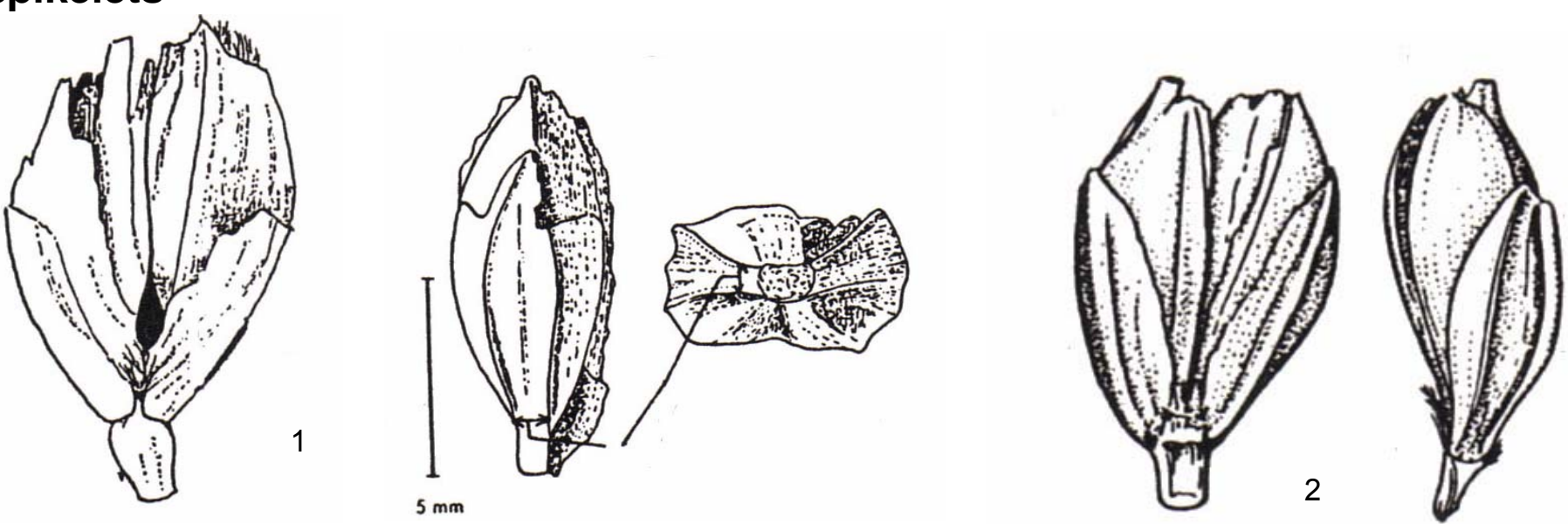

\section{spikelet forks}
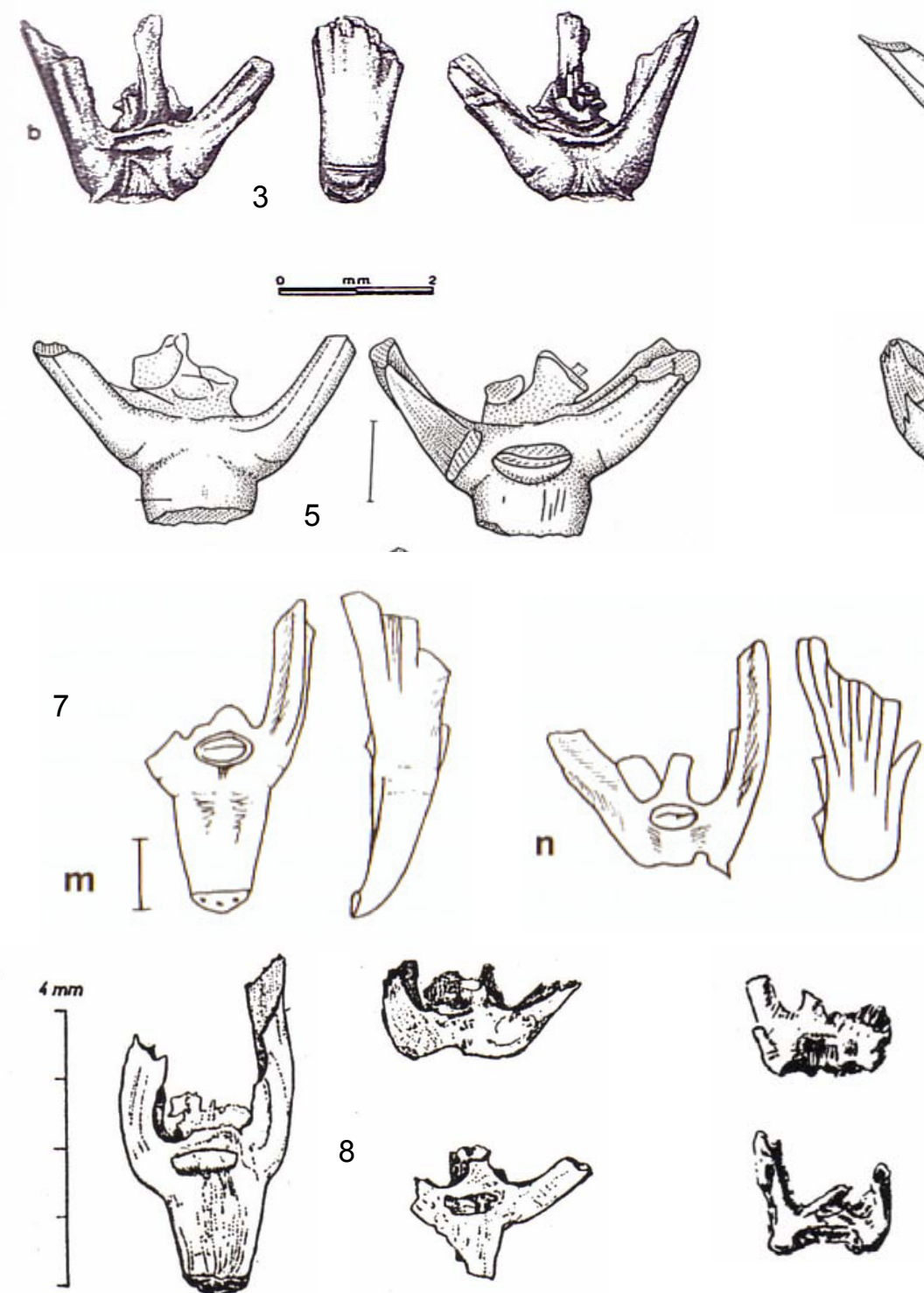

8
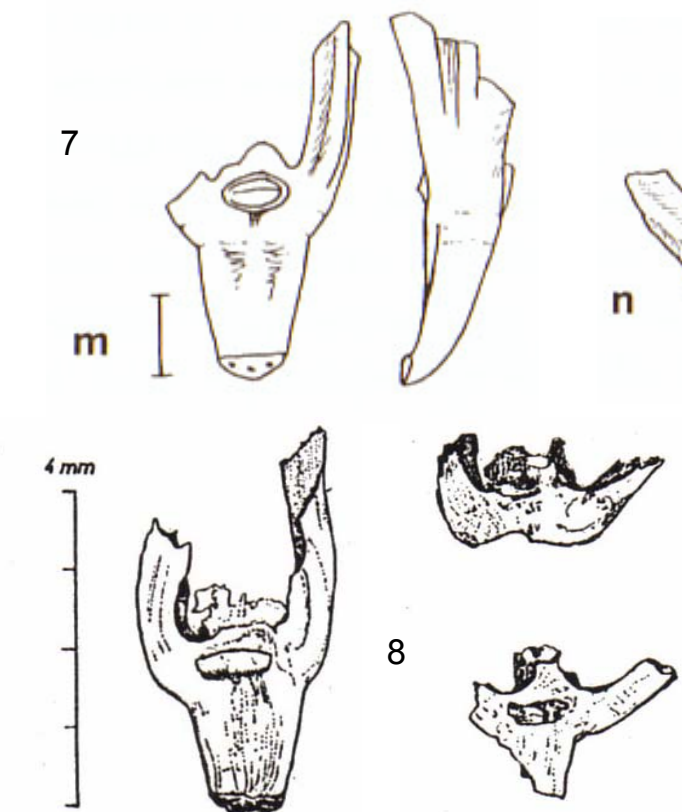
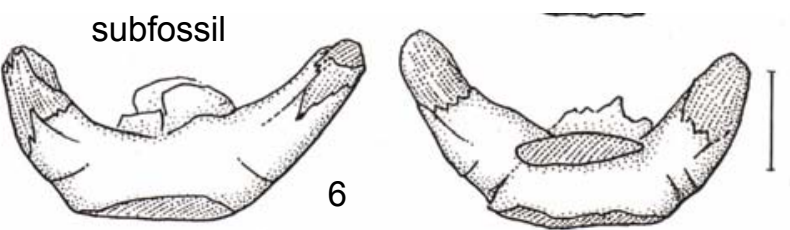

1: Feddersen Wierde (Iron Age, Northern Germany, Körber-Grohne 1967); 2 Ehrenstein (Neolithic, Germany, Hopf 1968); 3 Assiros (Bronze Age, Greece, Jones et al. 2000); 4-6 Zürich, Kleiner Hafner (Neolithic, Switzerland, Jacomet et al. 1989); 7 Stillfried (Late Bronze Age, Austria, KohlerSchneider 2001); 8: Burgäschisee-Süd (Neolithic, Switzerland, Villaret-von Rochow 1967); 9 Lamersdorf (Early Neolithic (LBK), Germany, Knörzer 
Images of (pre)historical finds of spelt (Triticum spelta):

\section{spikelets}

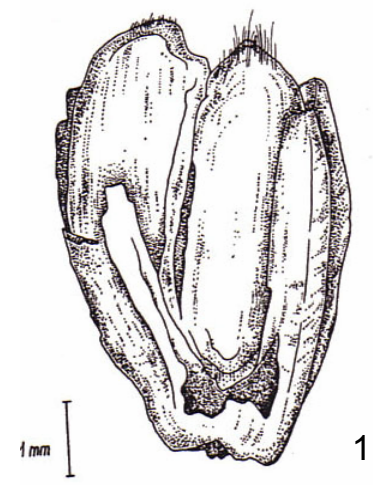

\section{spikelets and chaff}
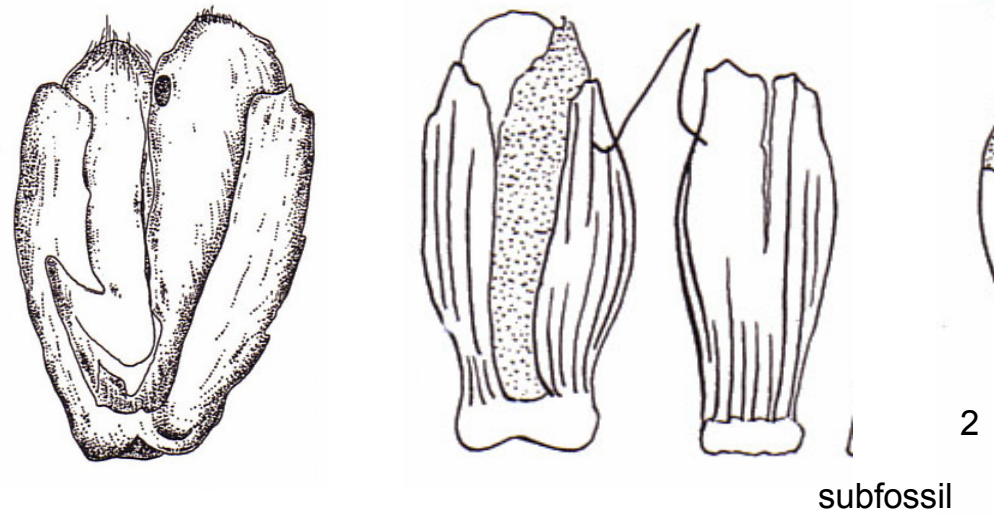

\section{spikelet forks and glume bases}
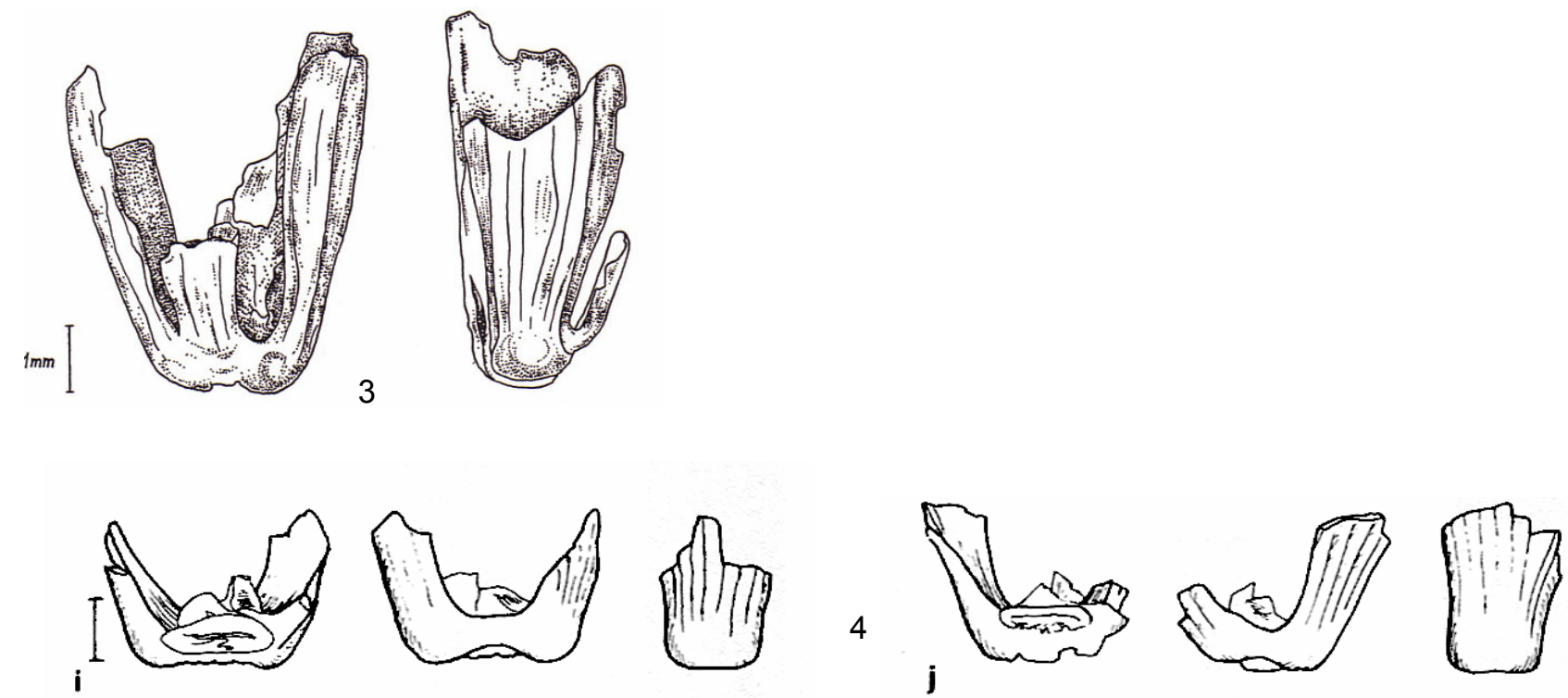

5
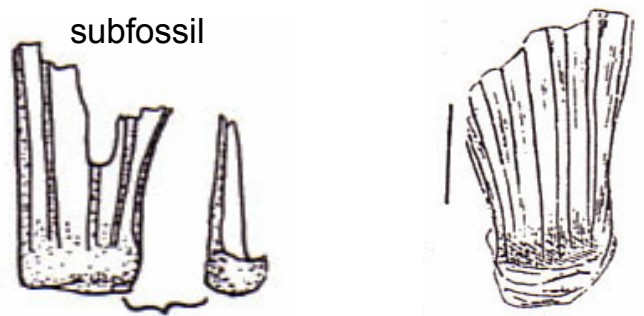

6

1, 3 Eptingen-Riedfluh (Middle Ages, Switzerland, Jacomet et al. 1988); 2, 5 Welzheim (Roman, Germany, Körber-Grohne \& Piening 1983); 4 Stillfried (Late Bronze Age, Austria, Kohler-Schneider 2001); 6 Zürich Mozartstrasse (Bronze Age, Switzerland, Jacomet et al. 1989) 


\section{criteria for distinguishing rachis remains of} tetra- and hexaploid naked wheat

The principal diagnosctic features of a portion of rachis of a free-threshing wheat. Note the distinction between " rachis segment " and « internode » (from Hillman et al 1996)

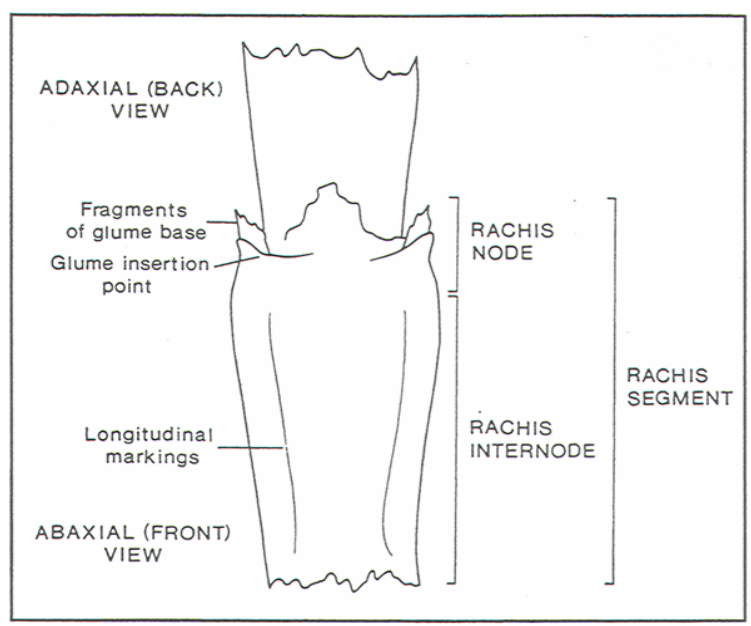

Rachis segments are certainly the first things to notice in the identification of naked wheat chaff, particularly their shape and size. The lower part of the glumes, which are mostly broken off, play a smaller role in this (compare glumed wheats). In the case of Neolithic cereals from lake shore settlements, however, it has been noticed that the lowest parts of the glumes often remain attached to the rachis (author's observations, see also e.g. Jörgensen 1975).

All naked wheat rachises were formerly, in the central European literature, without exception considered to belong to the hexaploids (see also grains). They were also placed in Triticum aestivum s.l. although some researchers, among them Heer in the early days, noted variations in the shape. In particular it struck Heer and for example Jörgensen (1975) in the case of Neolithic wheat material from the 'lake villages' of the sub-alpine region that the rachis segments showed unusual swellings underneath the glume attachment points. Jörgensen (1975) described the Neolithic rachis segments from Thayngen-Weier like this: "I have not seen such marked thickenings in extant collections of bread wheat and club wheat. Perhaps this feature is connected only with certain varieties of the species, or is strengthened in fossil material by carbonisation".

The presence of these swellings on the often apparently straight course of the side edges, the absence of a clear longitudinal striation in most cases and characters of the glumes (see below) already led the author to voice considerable doubt in the general classification of Neolithic naked wheat rachis segments as hexaploids (cf. Jacomet \& Schlichtherle 1984; see also Maier 1996). All the characters mentioned above fit much better with naked wheats of the tetraploid group (Triticum durum/turgidum). Characters for the differentiation of rachis segments of the two naked wheat groups was taken from the works of Schiemann (1948), Percival (1921) and Hervey-Murray (1980), and consequently the author has made various studies of recent material. In the same period also G. Hillman developed such criteria which finally were published in 2001 (see next page). The following crite ${ }^{-1}$.
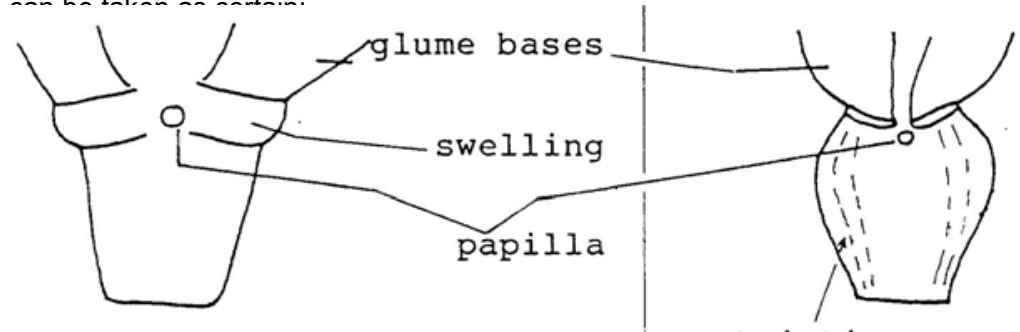

striations

\begin{tabular}{|c|c|}
\hline $\begin{array}{c}\text { Tetraploidea type } \\
\text { Triticum turgidum, T. durum }\end{array}$ & $\begin{array}{c}\text { Hexaploidea type } \\
\text { Triticum aestivum s.l. }\end{array}$ \\
\hline sides straight & sides curved \\
\hline striations absent & striations usually obvious \\
\hline thickenings (swellings) under the glume base & no thickenings (swellings) under the glumes \\
\hline glume parts often remaining attached to the rachis fragments & glume parts always broken off \\
\hline maximum width in upper part & maximum width just above the middle \\
\hline
\end{tabular}

The naked wheat rachis segments are of very different lengths (as are the ears, see the following pages). Almost all workers up to now concerned themselves with the question whether specific bread wheat types could be distinguished from club wheats (Triticum "compactum") (Villaret-von Rochow 1967, Jorgensen 1975). Jorgensen (1975), on the basis of extensive studies with recent material, came to the conclusion that this was not possible, for the club wheat dimensions lay completely within the variation of the bread wheats (in the strict sense). In charred material only pieces $>4 \mathrm{~mm}$ could be assigned to bread wheat $\mathrm{s}$. $\mathrm{s}$. with any certainty, and then with reservations. In naked wheat rachis material it is suggested on the basis of the author's results, to use the following groupings: tetraploid naked wheat type (turgidum type):

a1) long rachis segments $>4 \mathrm{~mm}$ (lax-eared type)

a2) short rachis segments $<4 \mathrm{~mm}$ (dense-eared type)

hexploid naked wheat type (aestivum type):

b1) long rachis segments $>4 \mathrm{~mm}$ (lax-eared type)

b2) short rachis segments $<4 \mathrm{~mm}$ (dense-eared type) 
T. DURUM GROUP (including

T. turgidum, T. turanicum and

T.polonicum
T. AESTIVUM GROUP (including

$T$. compactum $)+T$. sphaerococcum
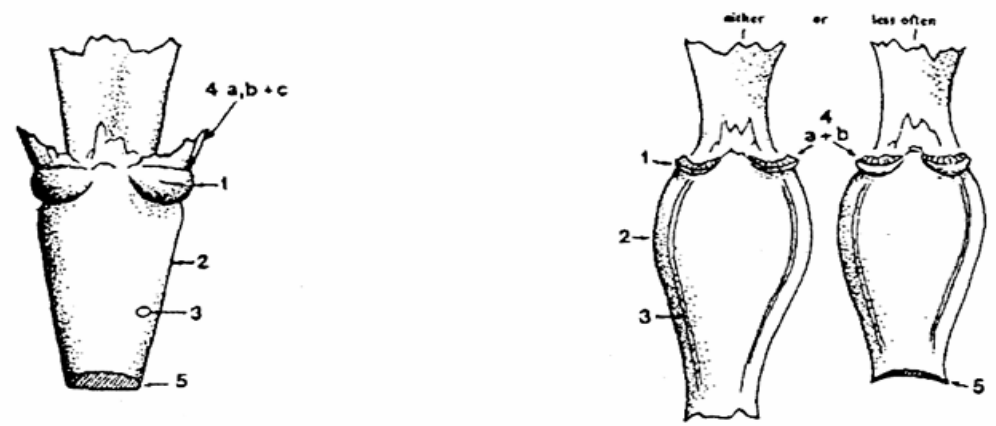

\section{1. shape of rachis node immediately below point of glume insertion}

Node often with a conspicuous rounded lump beneath each glume-insertion, with or without a thin fissure across the hump. (This feature is poorly developed in some small-eared pyramidal central Anatolian durums.)

2. Shape of rachis internode - in lax-eared forms only. (In dense-eared forms of either ploidy, there is insufficient room for internode shape to be properly expressed.)

Rachis internodes forming \pm straight-sided trapeziums, with only a slight incurved narrowing immediately below the node, even in extremely lax-eared tetraploids such as turanicum and polonicum.
Node with either (a) no lumps at all, and merely a narrow ridge below glume insert; or (b) weakly developed lower halves of lumps, in which the upper halves give the impression of having collapsed.
Rachis internodes conspicuously shieldshaped, with a strongly curved widening of the upper third of the internode, and a more steeply curved narrowing just below the node.

3. Presence/absence of longitudinal lines near the outer edge of the convex (abaxial) race of rachis internodes.

(This feature has so far proved the most reliable of all those listed here.)

No trace of lines, except those resulting from occasional wrinkles due to shrinkage if the ears were cut while still green.

Clear longitudinal lines present, often bearing hairs. The lines often have the following form in T.S.

Ridge often with hairs (The lines are just as conspicuous in compact/ dense-eared forms.)

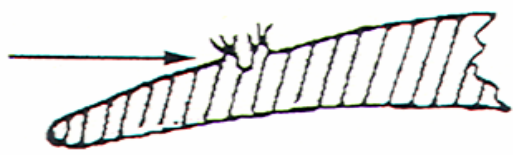

5. Roundness of rachis edge in transverse section.

Rachis edge in T.S. generally rounded. Rachis edge in T.S. generally attenuated.
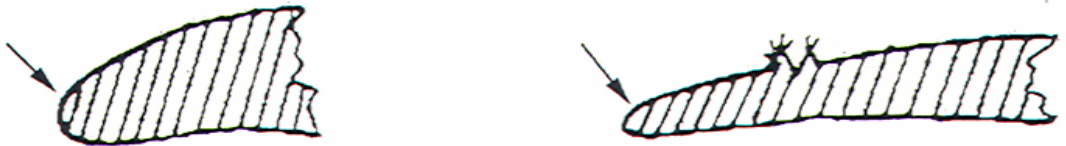


\section{images of (pre)historical finds of naked wheat : rachis remains}

Tetraploid 4n
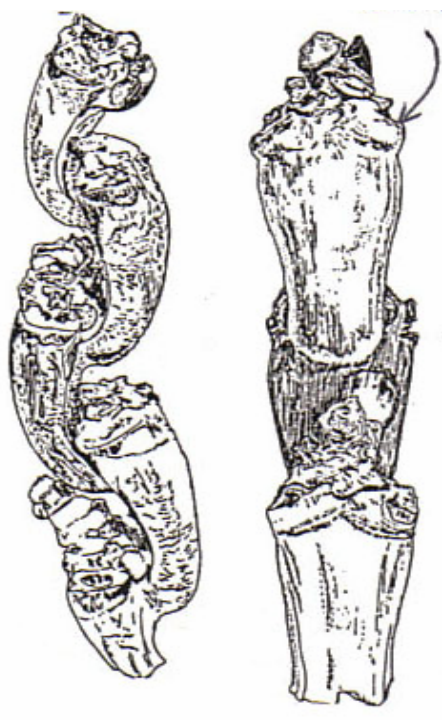

often glume bases attached

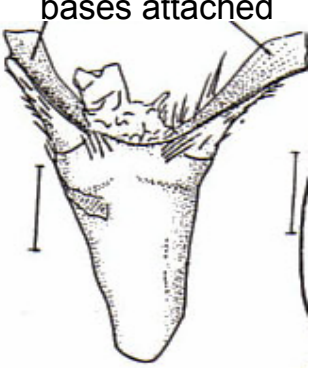

2

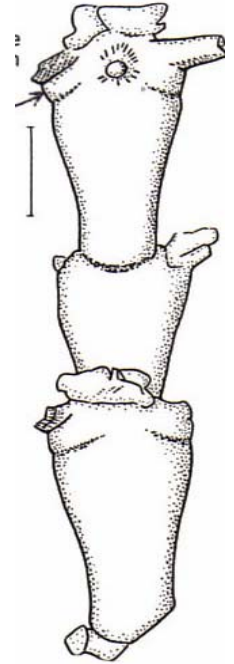

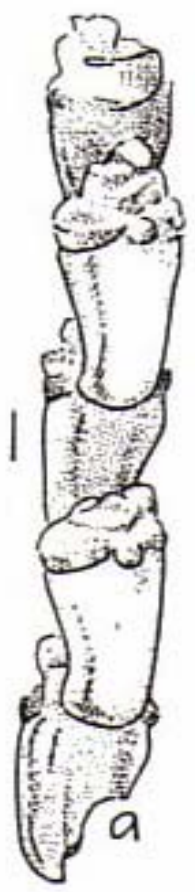

3

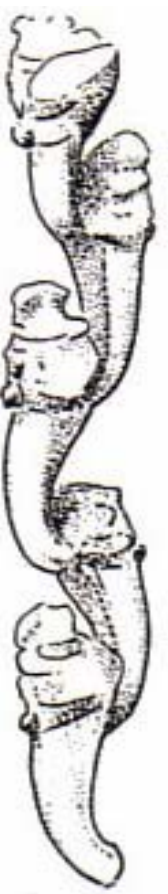

1-3, 6: rather long internodes (« lax-eared »), 4-5 short internodes (« dense-eared »)
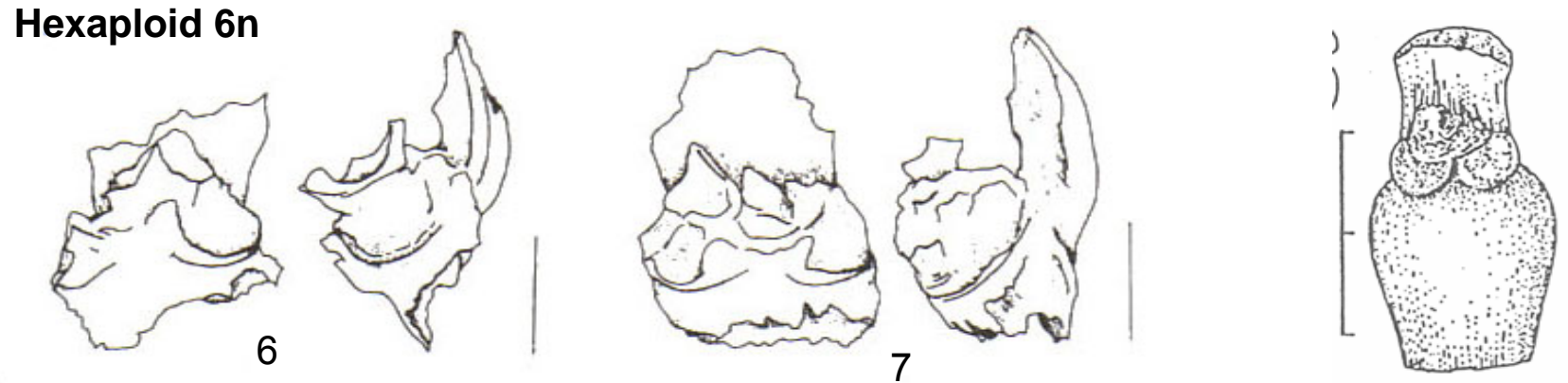

8
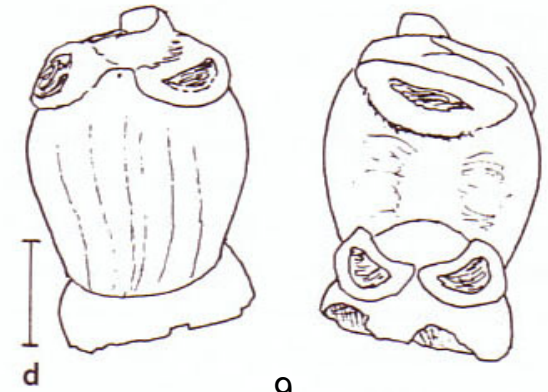

1, 4 Burgäschisee-Süd (Neolithic,

Switzerland, Villaret-von Rochow 1967); 2, 3,

5 Zürich, Kleiner Hafner (Neolithic,

Switzerland, Jacomet et al. 1989); 6, 7

Therwil Baslerstr. (Iron Age, Switzerland, Jacomet, not published); 8 Yverdon Avenue des Sports (Late Neolithic, Switzerland,

Schlichtherle 1985); 9 Stillfried (Late Bronze Age, Austria, Kohler-Schneider 2001) 


\section{Naked wheat glumes}

Glume fragments of naked wheat taxa are generally found infrequently. However they play a very important part, for example in the material from the waterlogged settlements in the sub-alpine region, where often whole ears or at least parts of them are found. It is therefore important to consider the glume characters of naked wheats in detail. Their shape can be taken from the figures below.

Morphological characters, of which particularly to be noted are:

- course and height of the main keel

- apical end of the main keel

- shouldering of the glume

- presence of nerves on the glume

- state of the glume base

The glumes also offer some important differential characters for the separation of hexaploid from tetraploid naked wheats

\begin{tabular}{|c|c|}
\hline $\begin{array}{c}\text { Tetraploidea } \\
\text { (T. turgium, T. durum) }\end{array}$ & $\begin{array}{c}\text { Hexaploidea } \\
\text { (T. aestivum s.I.) }\end{array}$ \\
\hline not shouldered, or only slightly & clearly shouldered \\
\hline No longitudinal folds at the base & clear longitudinal folds at the base \\
\hline No crosswise folds at the base & crosswise folds present at the base \\
\hline
\end{tabular}
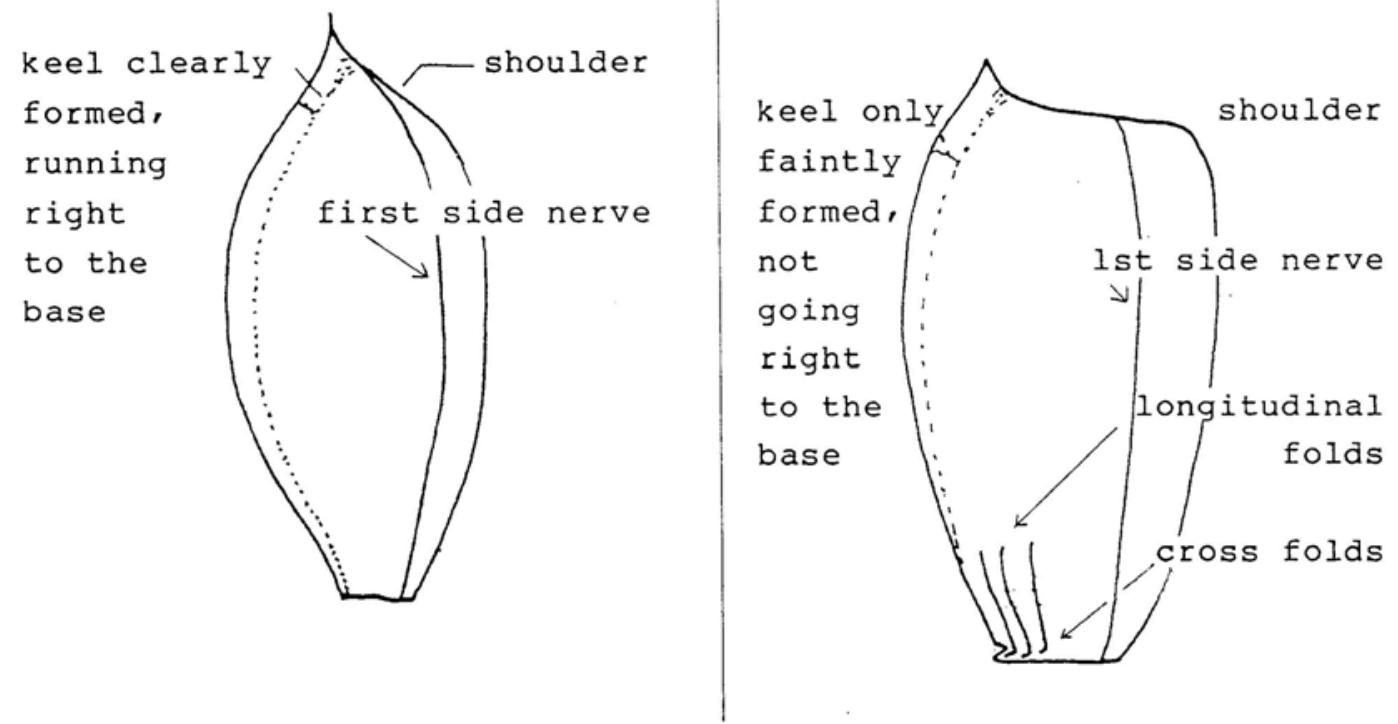

For identification the following groups had better be used:

a) tetraploidea type

b) hexaploidea type

c) not exactly identifiable

measurements for other parts of the ear: see on former pages
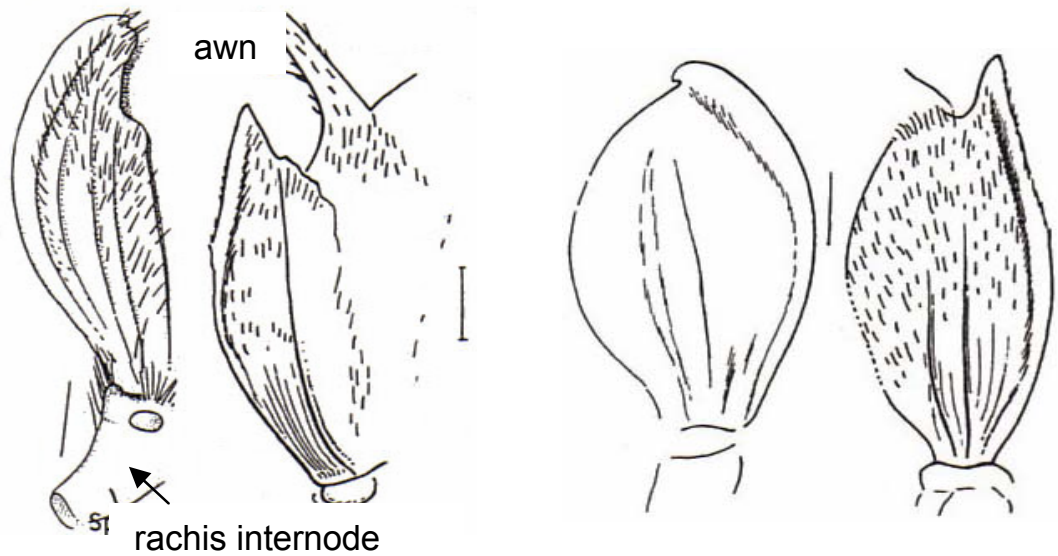

some examples of Neolithic 4n-naked wheat glumes: Zürich Kleiner Hafner (Switzerland, Jacomet et al. 1989) 
Images of (pre)historical finds of different wheats: ear-parts (very rare!)

\section{einkorn}
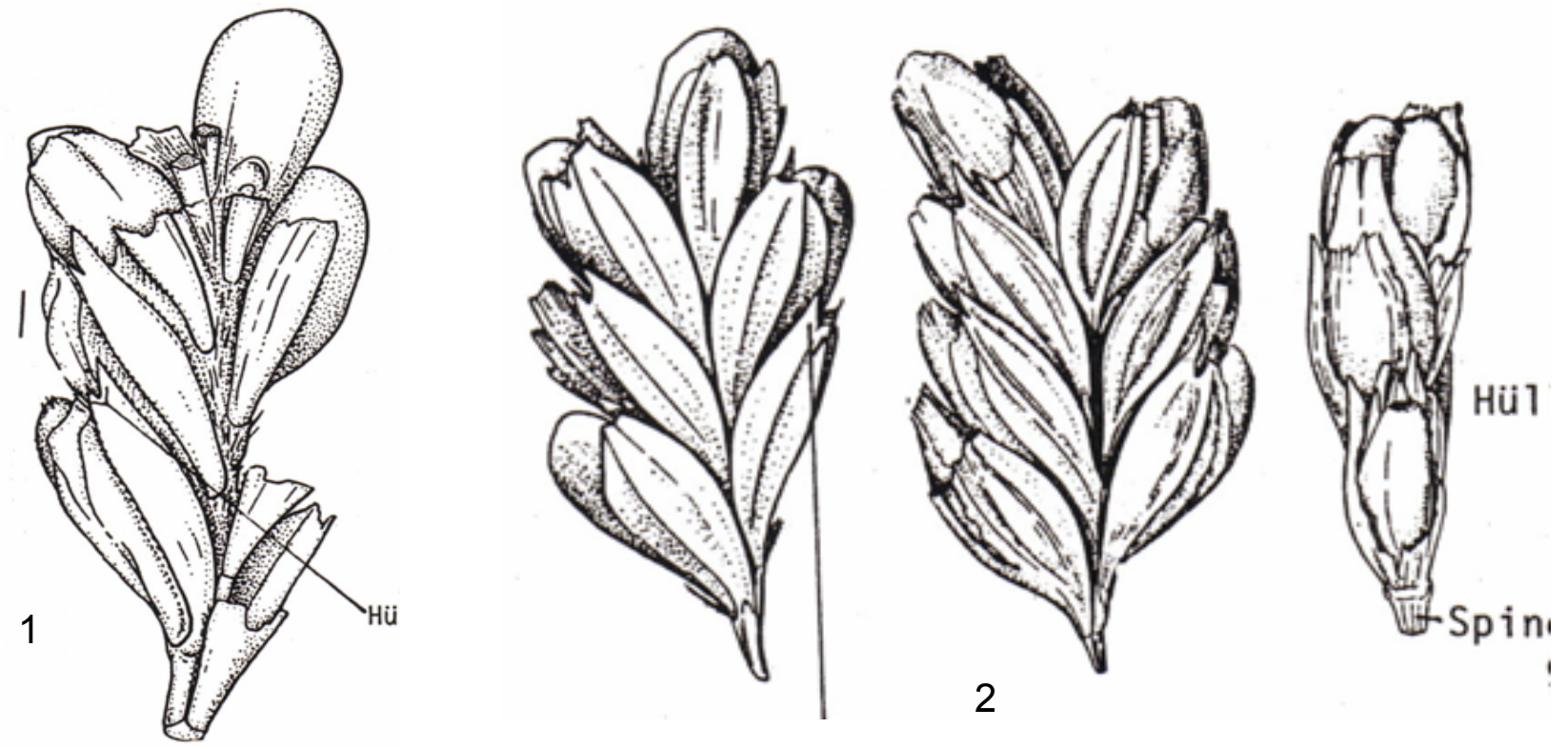

\section{tetraploid naked wheat}
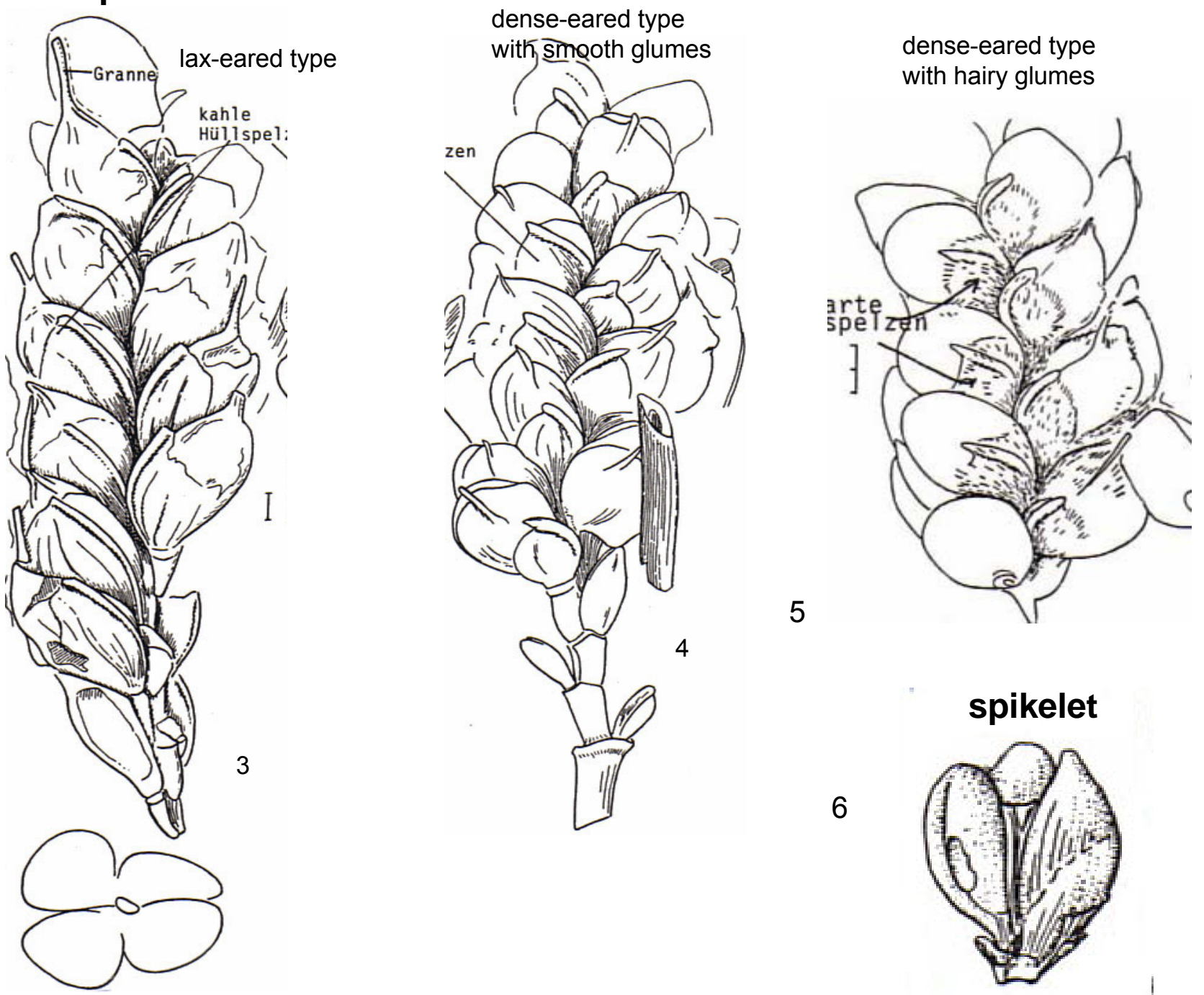

1 Port Stüdeli (Neolithic, Switzerland, Brombacher \& Jacomet 2003); 2, 6 Ehrenstein (Neolithic, Germany, Hopf 1968); 3-5: Zürich Kleiner Hafner (Neolithic, Switzerland, Jacomet et al. 1989); 
Origin: Wild grass with $2 n=14$ chromosomes (Hordeum spontaneum C. Koch), growing wild in the Near East in the Fertile Crescent area

\section{Morphological considerations}

-spikelets 1-flowered,

- glumes awn-like,

-lemma and palea with very long awns.

Taxonomy of the domestic forms (see also table at the beginning of part 2, for modern grouping see Zohary \& Hopf 2000):

Two main criteria for separation: -number ob fertile spikelets per rachis segment

-hulled or naked

Based on this on can distinguish between:

-two-rowed barleys: (Hordeum spontaneum and $\mathrm{H}$. distichum L.) with only one fertile spikelet, the central one, per rachis segment; the 2 outer (=lateral) ones are sterile.

There are naked and glumed (hulled) forms.

-many-rowed barleys (also: 6rowed) (Hordeum vulqare L.) with 3 fertile spikelets per rachis segment. There are:

$\checkmark$ dense-eared forms (the

"classical" six-rowed forms, var. hexastichum)

- lax-eared forms (the so called 4rowed barley, var. tetrastichum; in the literature also known as "laxeared six-rowed")

Of both there are hulled and naked (var. nudum) forms.

The genetic differences between the various forms are slight (see e.g. Salamini et al. 2002).

Further useful literature: Charles 1984, Bouby 2001
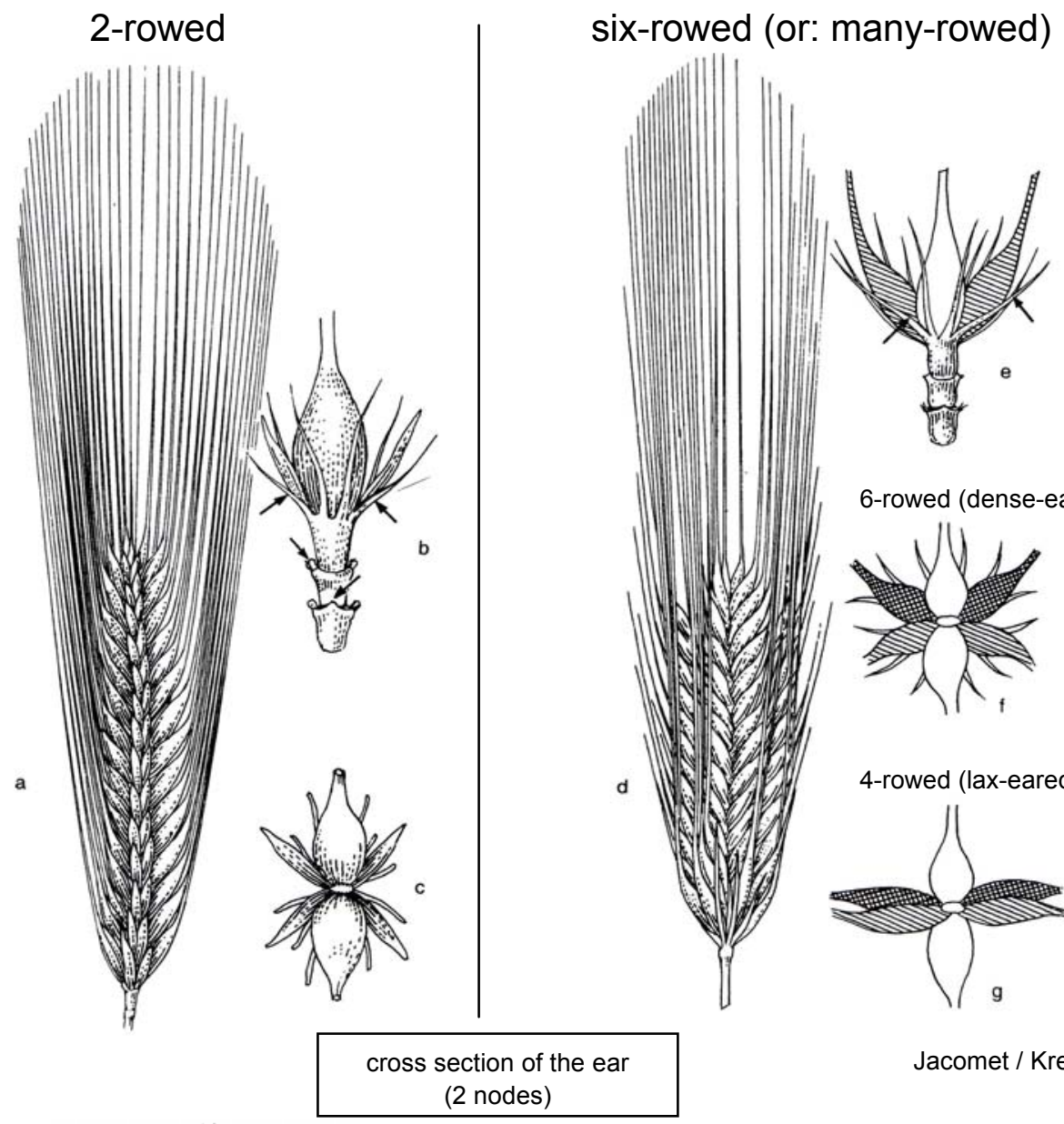

6-rowed (dense-eared)

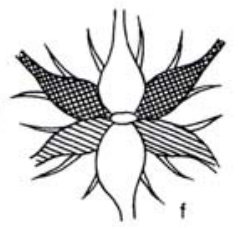

4-rowed (lax-eared)

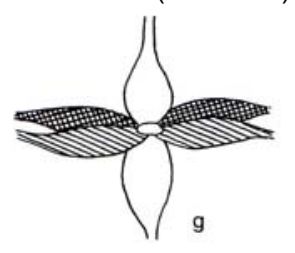

Jacomet / Kreuz 1999
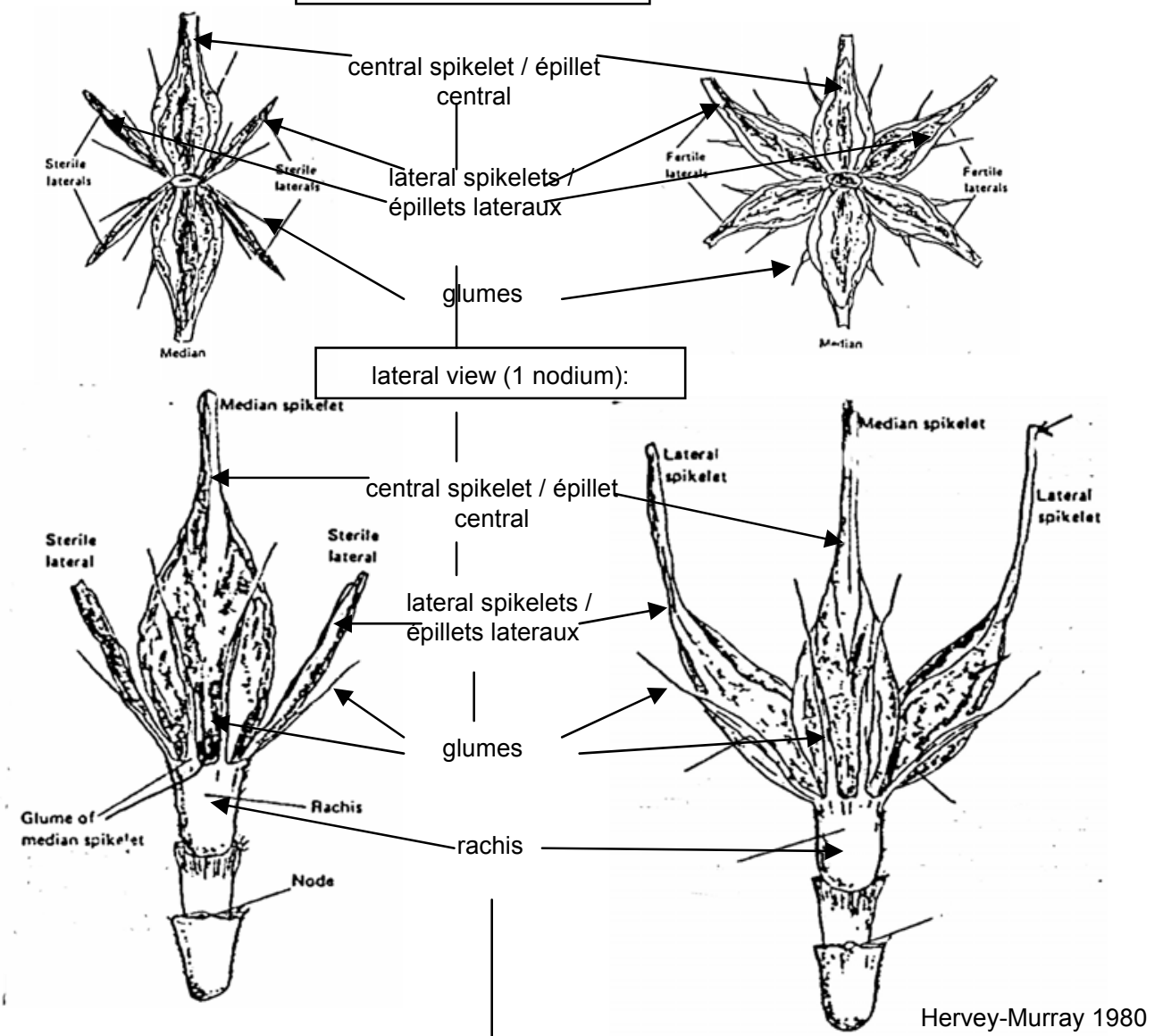
after threshing / hulled form

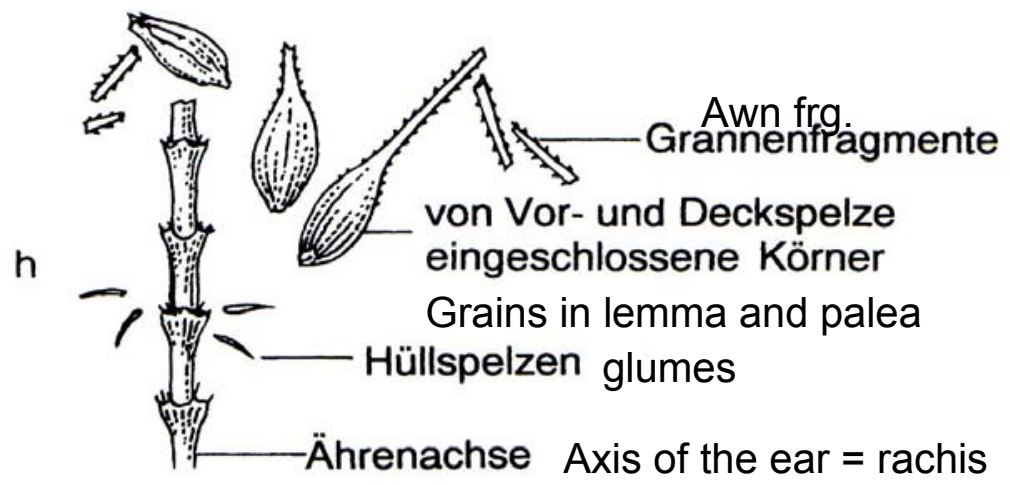

grain:

central 6-row or 2-row grain, husks removed

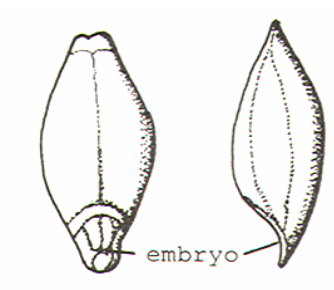

DORSAL

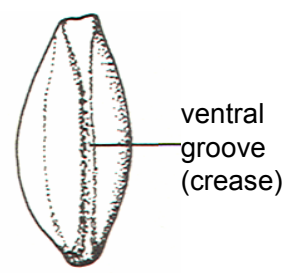

VENTRAL

Charles 1984

\section{Grains (and lemma):}

- Shape seen from the dorsal or ventral side: spindle-shaped, more or less pointed / tapering at the top and bottom.

- Shape seen from the side (lateral view): spindle-shaped too, relatively flat. Highest part more or less in the middle. For differences to wheat see the figures on the next page

- in hulled barley the lemma (and palea) is closely attached to the grain, and its basis provides useful characters for the distinction of the forms (see next pages)

- Special characteristics: see under the various taxa, see next pages

- Measurement lines see former pages

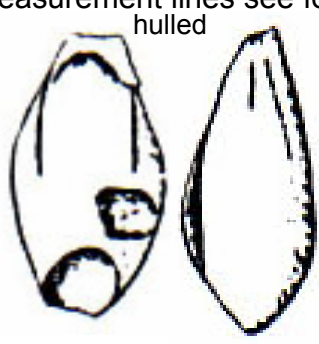

do.
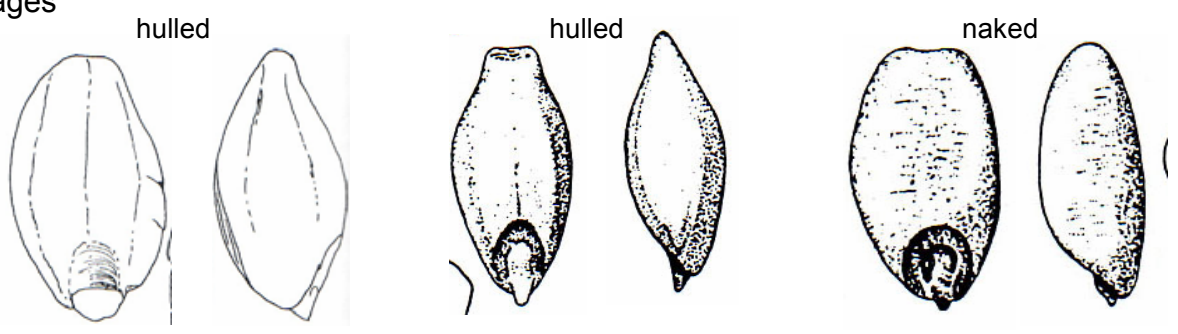

Rachis segments:

Shape various (see the various taxa, next pages When preservation is good, the narrow glume attachments can be seen at the top ( $\mathrm{H}$ on the 2 left figures below). From the front one can see 4 (the 2 of the middle floret and another (=the front) of the lateral florets), from the back 2 (the rearmost of the 2 lateral florets). In contrast to wheat the rachis is very straight (in lateral view; see comparison on the next page).

Measurement lines see former pages

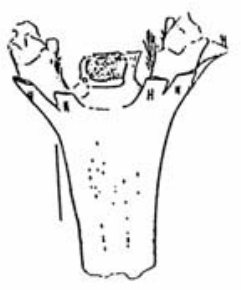

adaxial

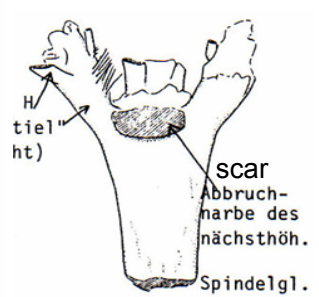

abaxial
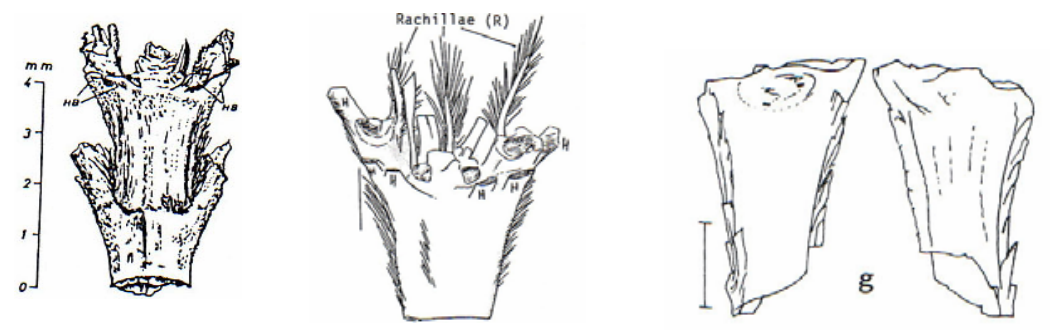

The identification of barley remains is difficult and particularly confusing for beginners because there are so many varieties. We shall deal with two levels of approach:

a) separation of two-rowed from multi-rowed forms $(\underline{\mathrm{H}}$. distichon from $\underline{\mathrm{H}}$. vulgare $)$

b) separation of multi-rowed forms from each other:

b1) lax-eared or dense-eared

b2) hulled or naked

The most important identification characters are summarised in the tables on the next pages 


\section{grains}

Barley- and wheat-remains: a comparison

barley
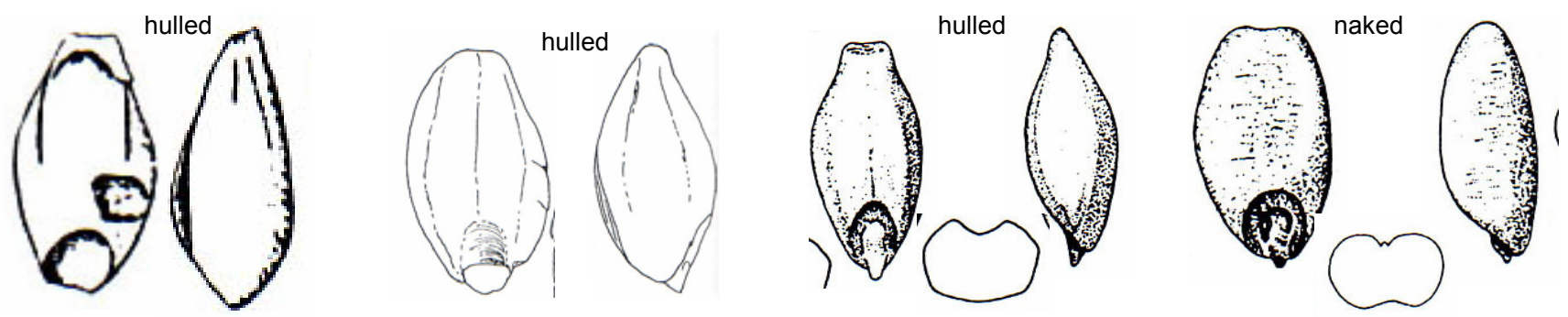

einkorn
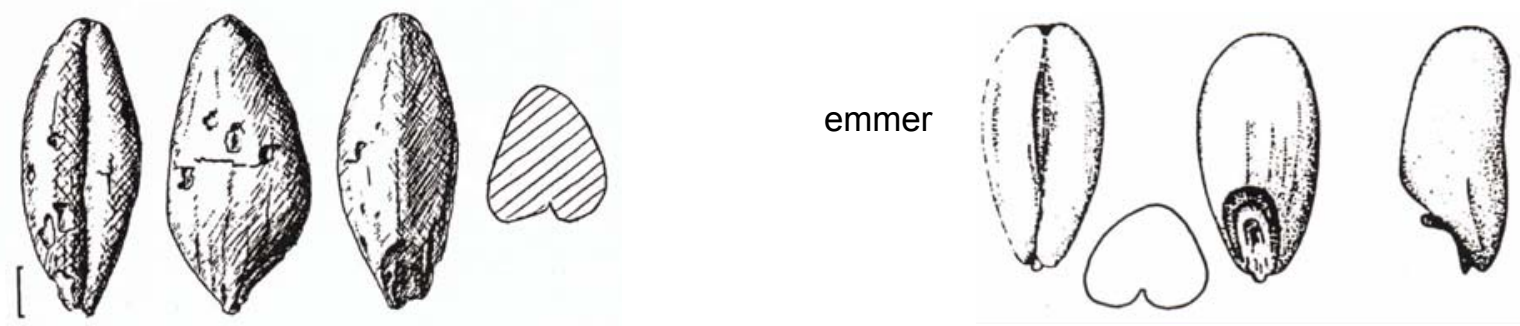

spelt
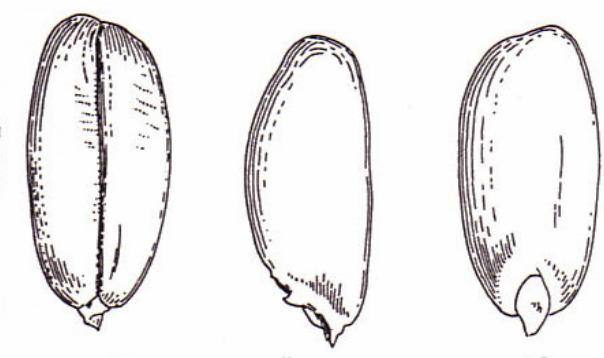

naked wheat
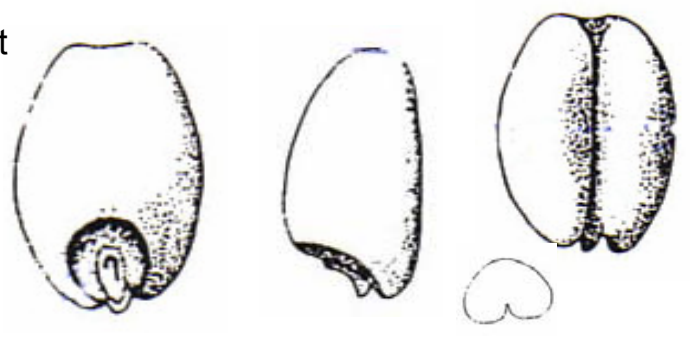

rachis remains

barley
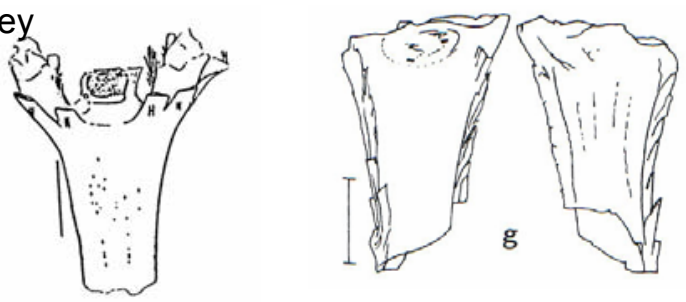

naked wheat
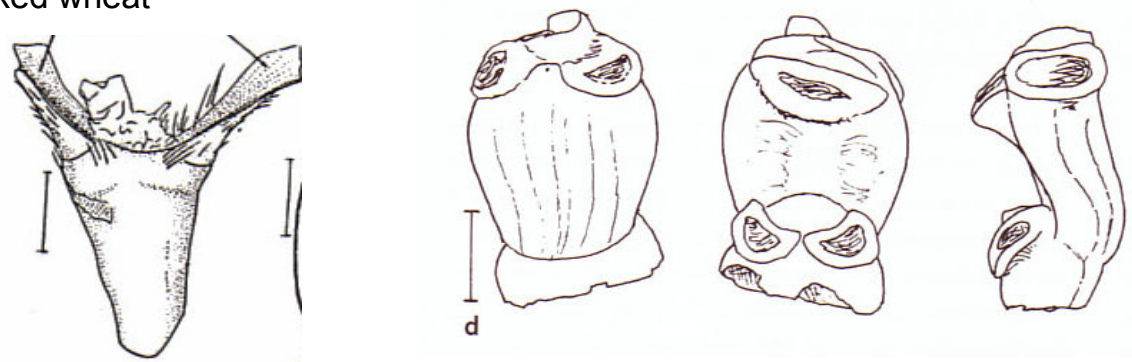


\section{Barley: Differences between six-rowed and two-rowed barley}

\begin{tabular}{|l|l|l|}
\hline part & many-rowed barley & two-rowed barley \\
\hline EARS & $\begin{array}{l}3 \text { fertile spikelets per rachis } \\
\text { segment }\end{array}$ & $\begin{array}{l}1 \text { fertile spikelet per rachis } \\
\text { segment = middle spikelet. Both } \\
\text { side ones are stunted. }\end{array}$ \\
\hline $\begin{array}{l}\text { SPIKELETS } \\
\text { depression in lemma base }\end{array}$ & $\begin{array}{l}\text { Lax-eared forms (4-rowed): } \\
\text { horseshoe shaped. Dense-eared } \\
\text { forms (6-rowed): small fold. }\end{array}$ & horseshoe shaped \\
\hline GRAINS & $\begin{array}{l}\text { straight and twisted grains present } \\
\text { (particularly in lax-eared forms). } \\
\text { Proportion of twisted : straight } \\
\text { grains theoretically 2:1. } \\
\text { maximum width of grain: at centre }\end{array}$ & $\begin{array}{l}\text { only straight grains present } \\
\text { somewhat below the centre of the } \\
\text { grain }\end{array}$ \\
\hline $\begin{array}{l}\text { RACHIS SEGMENTS } \\
\text { bases of the side florets }\end{array}$ & $\begin{array}{l}\text { well-formed bases of the side } \\
\text { florets }\end{array}$ & $\begin{array}{l}\text { bases of the side florets somewhat } \\
\text { stunted }\end{array}$ \\
\hline
\end{tabular}

These criteria can be used for charred material

six-rowed (many-rowed) barley: asymmetrical grain from one of the lateral spikelets and the 3 fertile spikelets of one node of the rachis (Bouby 2001 and Van Zeist 1984)

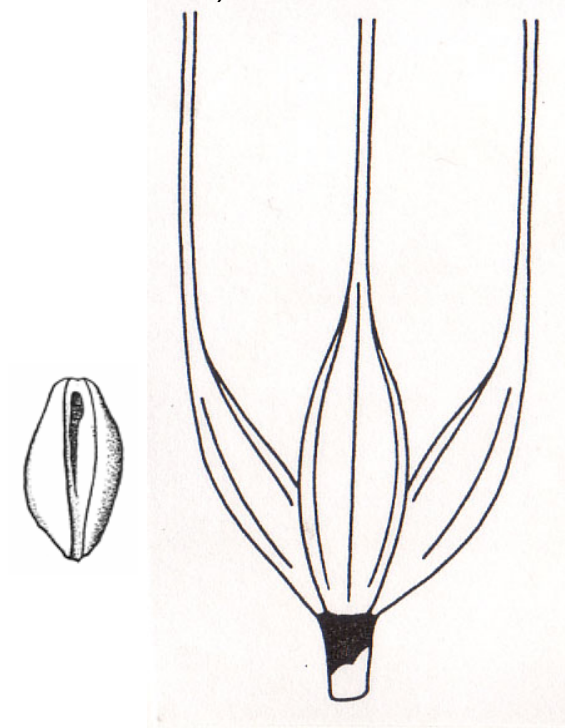

Two-rowed barley: straight grain of the central spikelet and the one fertile and the 2 reduced spikelets of one node of the rachis (Bouby 2001 and Van Zeist 1984) 


\begin{tabular}{|c|c|c|}
\hline part & dense eared $=6$ row & lax-eared $=4$ row \\
\hline $\begin{array}{l}\text { SPIKELETS depress ion in the } \\
\text { lemma base }\end{array}$ & $\begin{array}{l}\text { spkelets arranged in threes } \\
\text { (seen from above) } \\
\text { (seen from side) } \\
\text { slim, furr ouved: inte rmediates! }\end{array}$ & $\begin{array}{l}\text { spikelets arranged in threes } \\
\text { (seen from above) } \\
\text { (seen from side) } \\
\text { horseshoeshaped }\end{array}$ \\
\hline $\begin{array}{l}\text { GRAJNS: } \\
\text { shape }\end{array}$ & $\begin{array}{l}\text { rounded = short and wide LG } \\
\text { index }<1.8 ; \text { there are } \\
\text { intermediates! }\end{array}$ & slim-oval $L B$ ind ex $>1.8$ \\
\hline Tuvist & $\begin{array}{l}\text { twisting of the side grairs not } \\
\text { cle ar }\end{array}$ & $\begin{array}{l}\text { mamy touisters present in finds. } \\
\text { Theoretical ratio touisted: straight } \\
\text { 2:1 (2). Does not actually occur. }\end{array}$ \\
\hline $\begin{array}{l}\text { RACHIS SEGMEN TS; } \\
\text { shape: }\end{array}$ & $\begin{array}{l}\text { wide in ratio to length; wide base } \\
(0.6-1.3 \mathrm{~mm})(3) \text {. }\end{array}$ & $\begin{array}{l}\text { slim, sharphy tapering at the } \\
\text { base; narrow base (wuidth } 0.41 .1 \\
\text { mm ( } 3 \text { ). Length'breadth (base) } \\
3.4 \text { to } 2.9 \text { ( } 3 \text { ). According to } \\
\text { author's measurements of } \\
\text { modern material: }>3 \text { or scarcely } \\
\text { less than } 3 \text {. }\end{array}$ \\
\hline length: & $\begin{array}{l}13-2.4 \text { (1). Qwn obsenations on } \\
\text { modern material: the variation } \\
\text { across one ear is veny great The } \\
\text { above counts are only for the } \\
\text { middle part of the ear. }\end{array}$ & length $2.3-3.45 \mathrm{~mm}$ (1) \\
\hline hairs on edges: & $\begin{array}{l}\text { pronounced. according to (2) this } \\
\text { char acter is irrelevant. }\end{array}$ & slighthy hairy (4) \\
\hline side spikelets on "staks" & $\begin{array}{l}\text { stak very much reduced, hard to } \\
\text { see }\end{array}$ & $\begin{array}{l}\text { stak cle ar by visible; high } \\
\text { attachment points of the rear } \\
\text { glumes of the side florets (see } \\
\text { Table 4) }\end{array}$ \\
\hline
\end{tabular}

There are no "staks" on the side spkelet of hulled barley! 


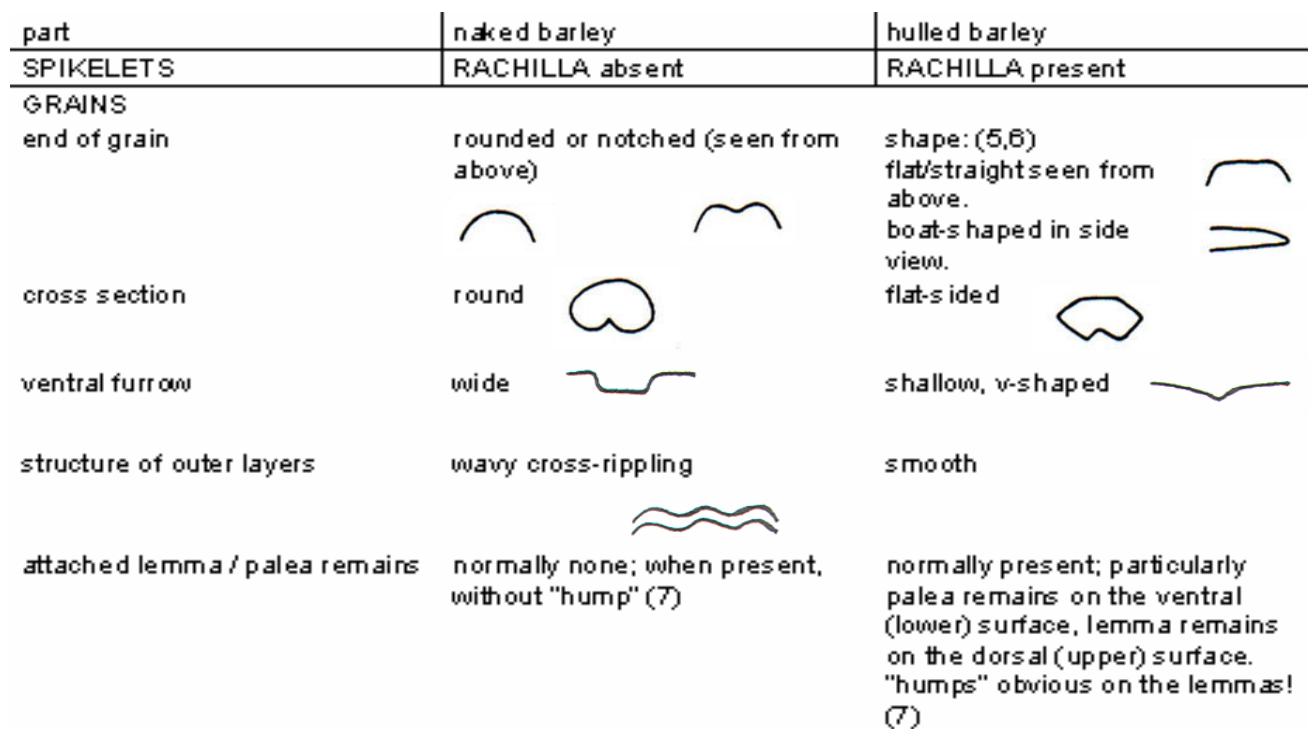

According to the author's obsenuations the presence or absence of the "humps" on the lemmas is a problematic char acter, for the formation of the hump changes with the degree of charring of the find. Besides, lemma remains can remain attached to grain ako in the case of naked barleys (see text).

\begin{tabular}{l|l|l}
\hline RACHIS SEGMENTS & part of the lemmas and paleas & all glumes/lemmasipaleas \\
glume bases attached to the & present, rachilla still attached \\
rachis segments & (somenhan off, with the exception of \\
appearance) & the lemma bases. Rachilla \\
broken off("clean appear ance")
\end{tabular}

Problematic

This character works in cases where an ear broke up in an uncharred state and the parts charred separ ate by. When the ears and consequently their parts charred when joined together and only then broke up, this character can onby be used with caution, as the author's charring experiments showed. Also, the separation of lax-eared forms is less difficult than for derse-eared types.

"Staks" of the side florets (real staks in the serse of (3).

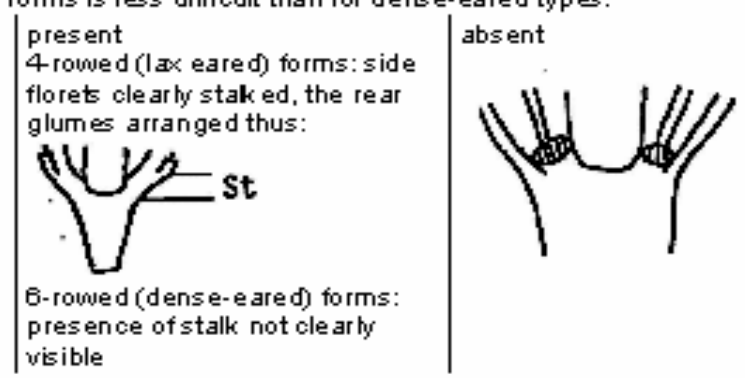

Zusammengestellt nach Angaben aus der Literatur (Villaret- von Rochow 1967, van Zeist 1968, Piening 1981 und mündliche Mitteilung, Helbaek 1952A + B, Kroll 1987 und Körber-Grohne \& Piening 1980) und eigenen Beobachtungen an Vergleichsmaterial. Zusammenstellung: S. Jacomet. 
ears, spikelets and rachis parts
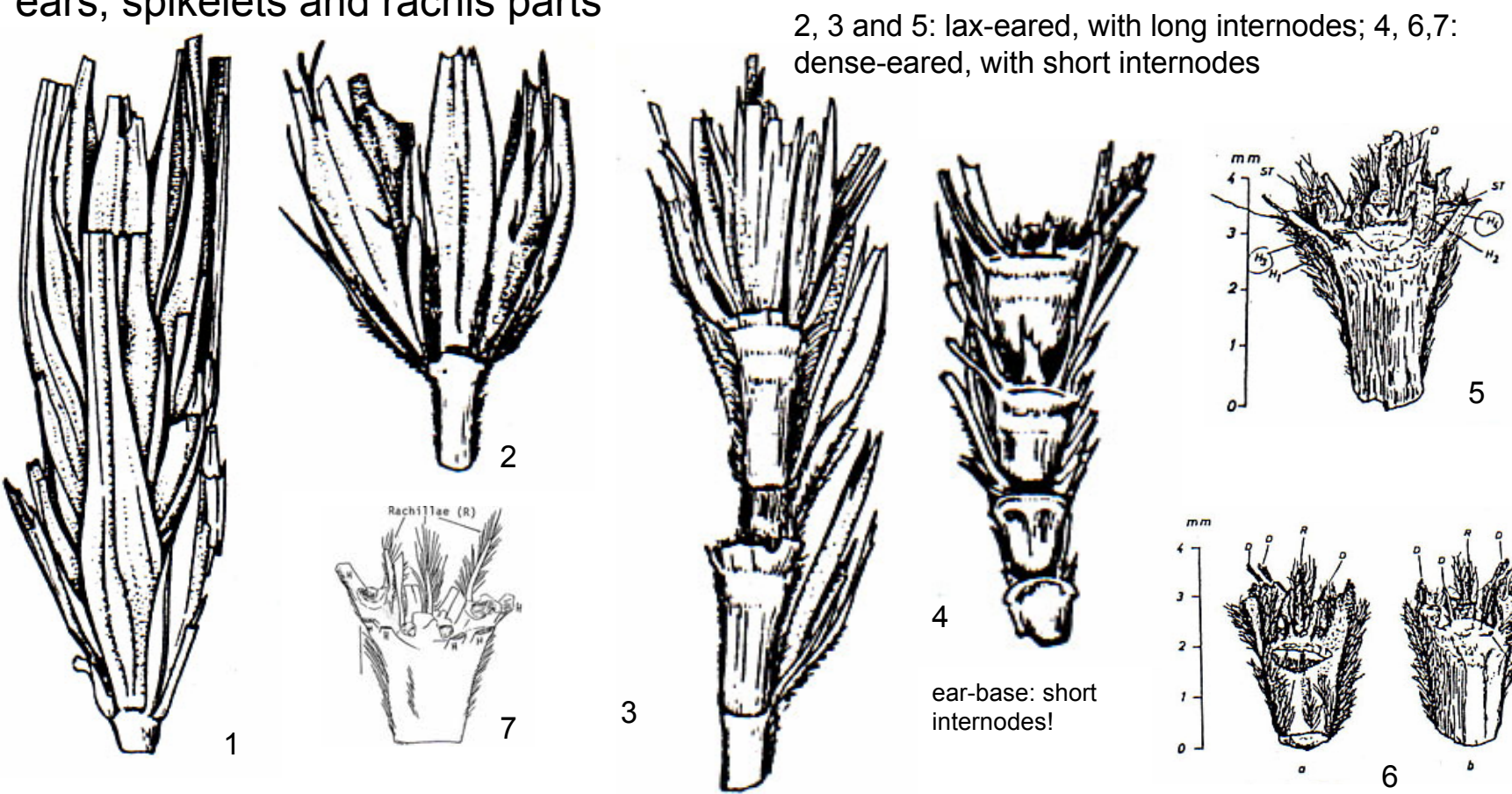

ear-base: short internodes!
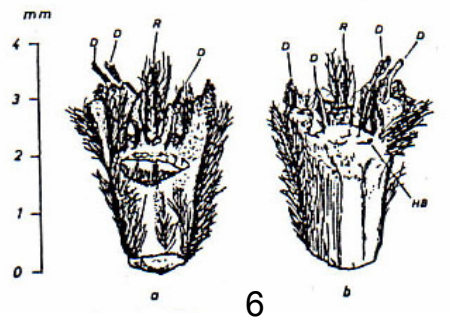

grains: mostly rather slender forms
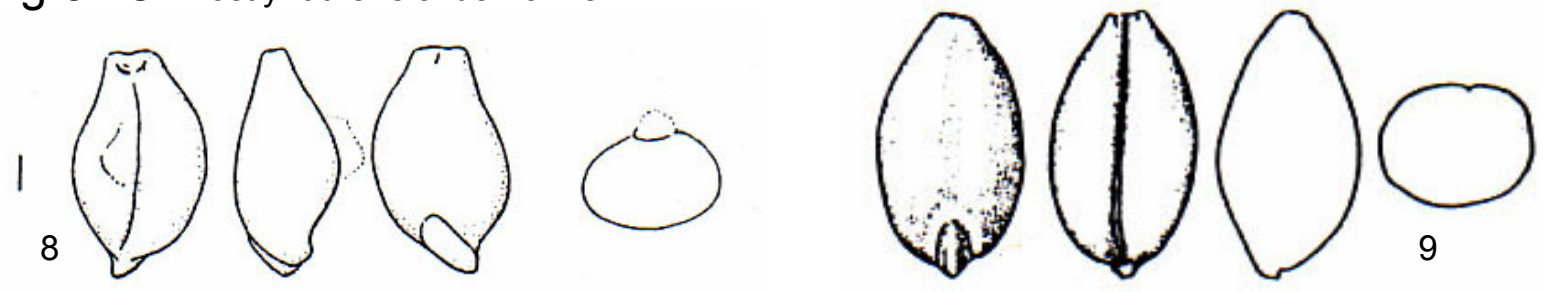

asymmetrical and diostorted (above) grains: lax-eared
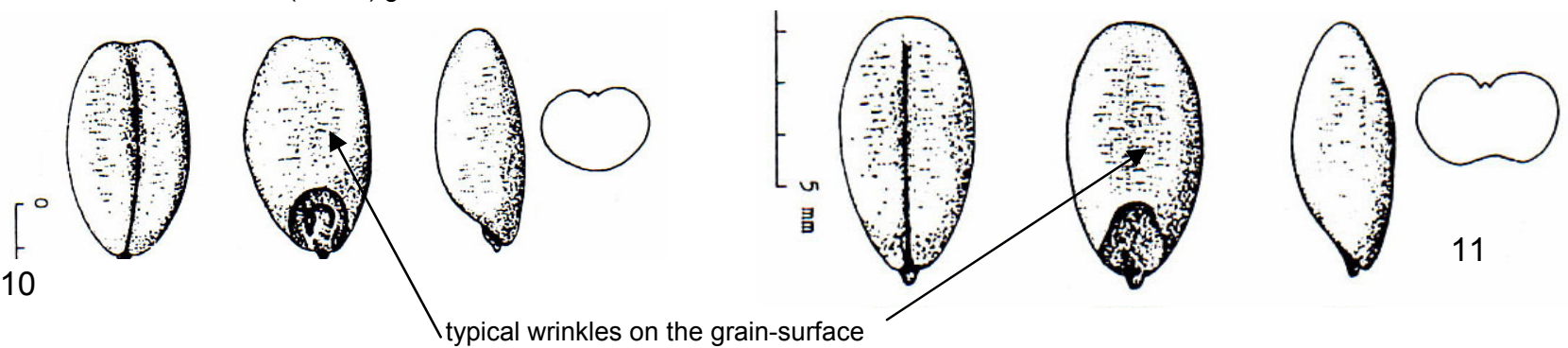

10

\section{Raphe}
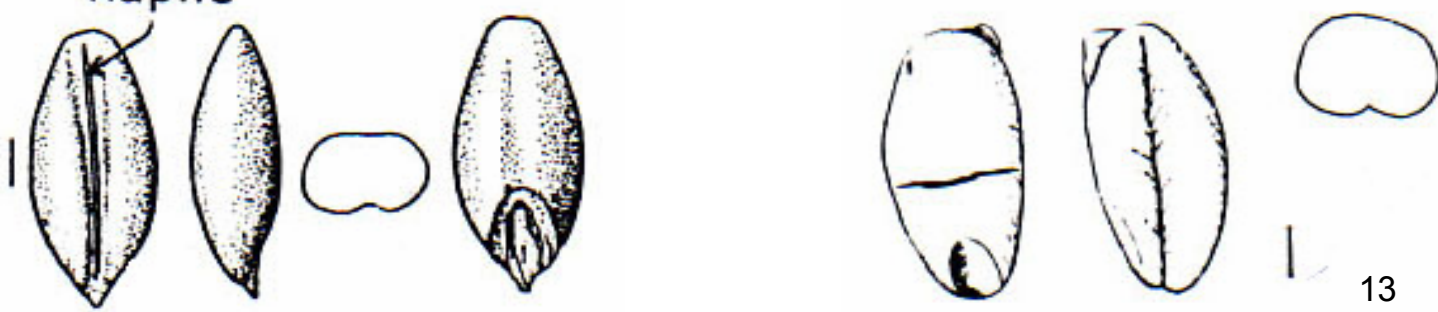
rachis remains
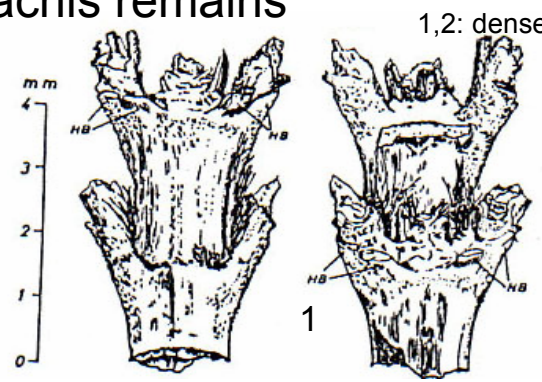

3-5: lax-eared
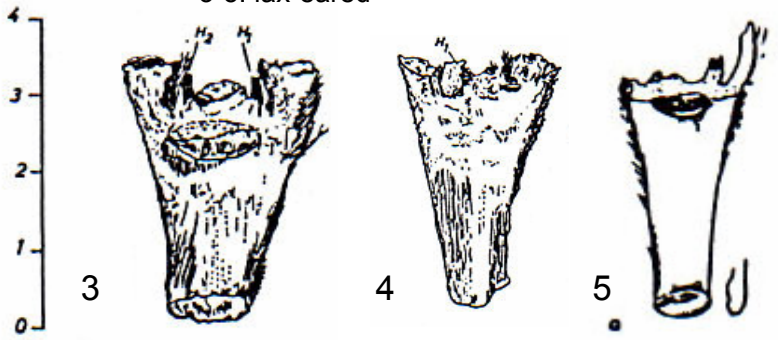

grains: 6, 7, 10: rather roundish grains (cf. from dense-eared forms), the others rather slender (cf. from lax eared forms)
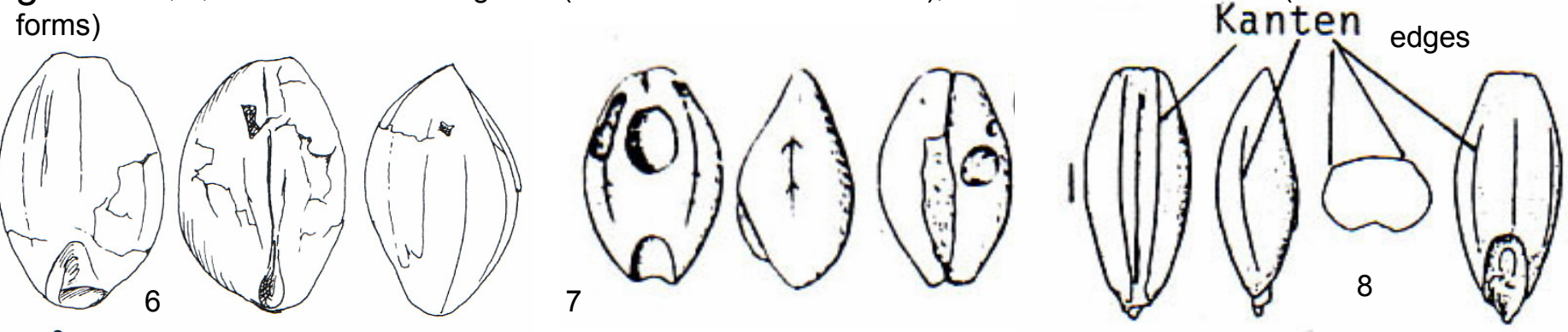

$c$
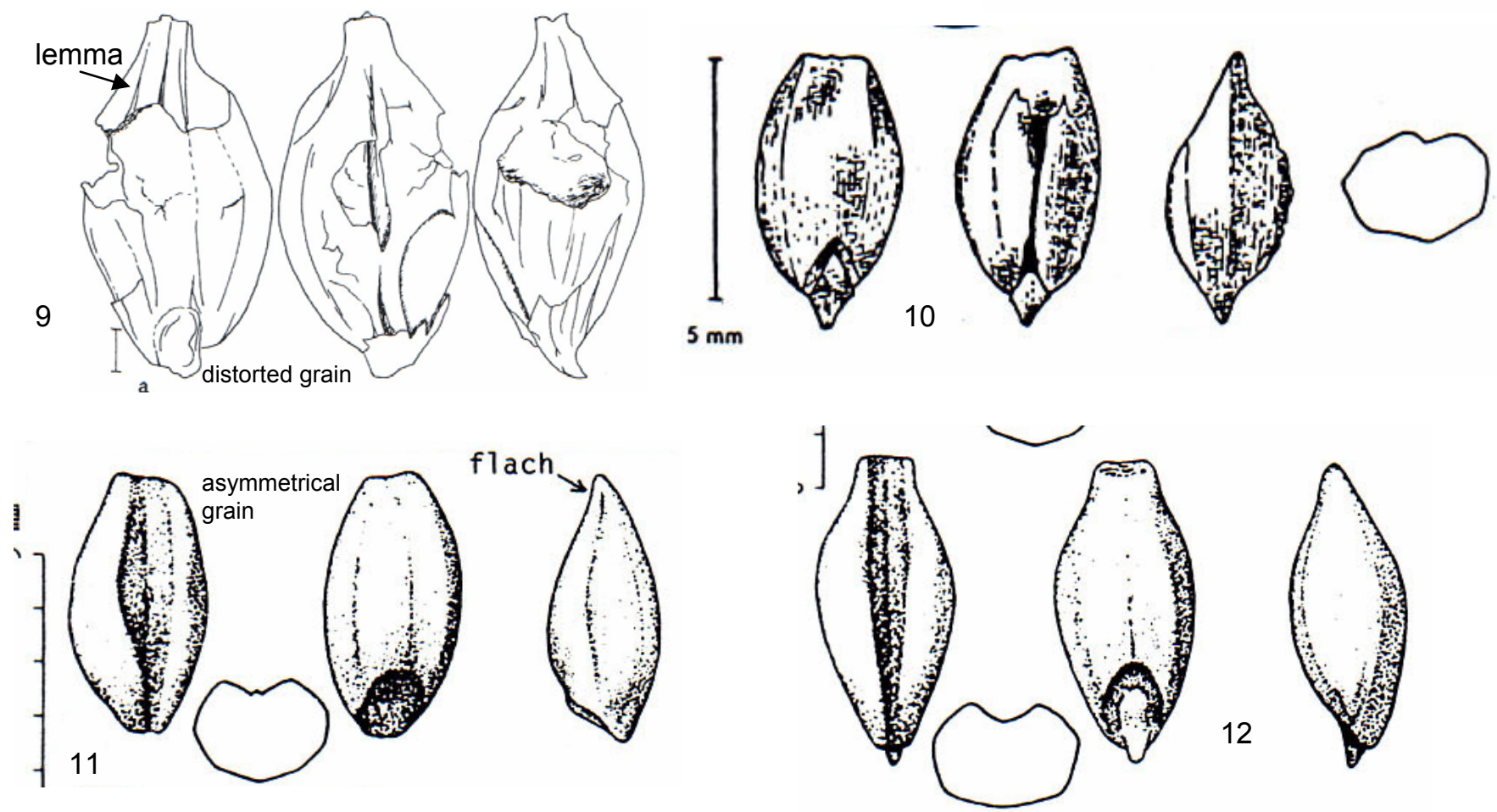

12
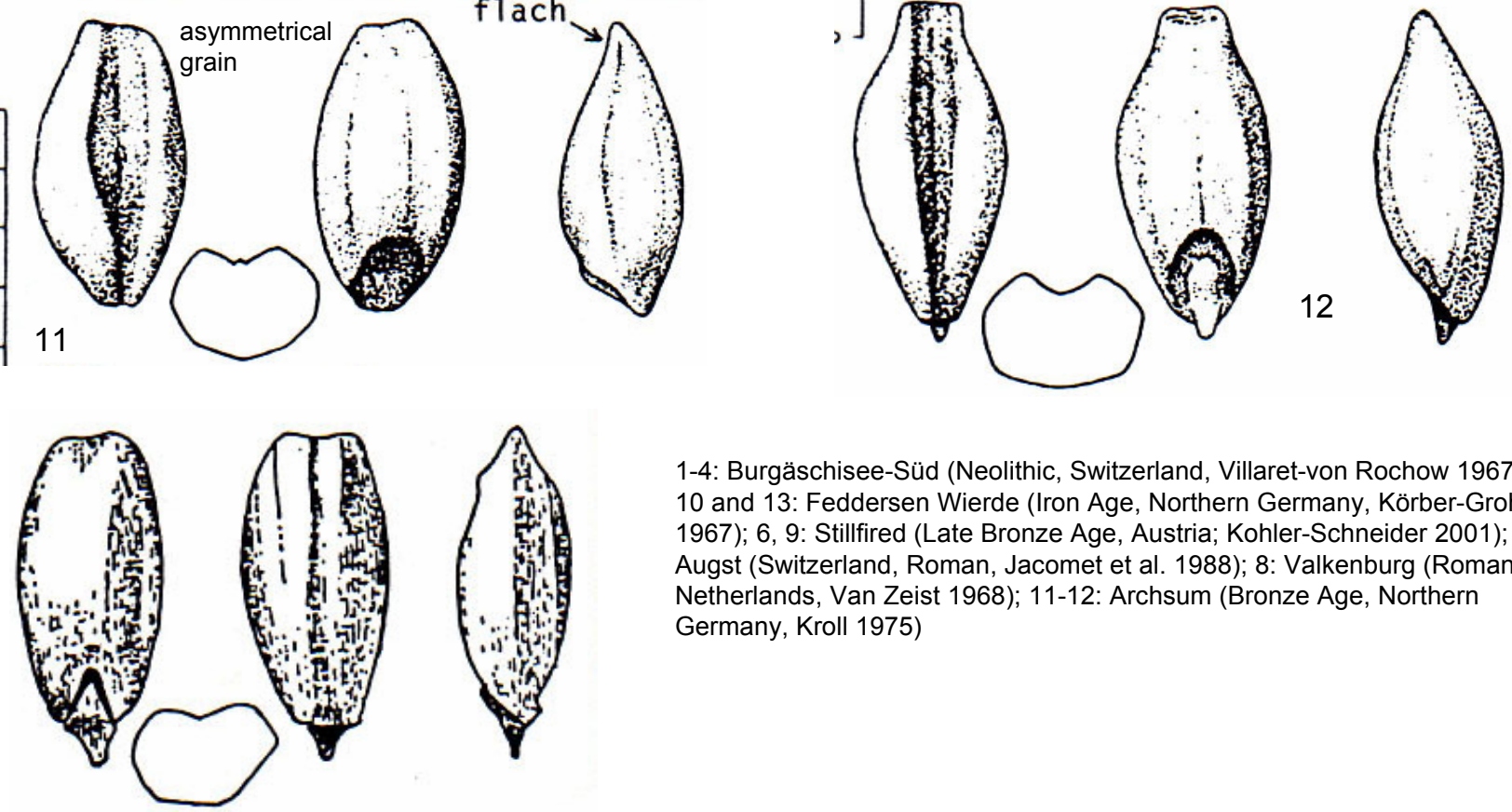

1-4: Burgäschisee-Süd (Neolithic, Switzerland, Villaret-von Rochow 1967); 5, 10 and 13: Feddersen Wierde (Iron Age, Northern Germany, Körber-Grohne 1967); 6, 9: Stillfired (Late Bronze Age, Austria; Kohler-Schneider 2001); 7 : Augst (Switzerland, Roman, Jacomet et al. 1988); 8: Valkenburg (Roman, Netherlands, Van Zeist 1968); 11-12: Archsum (Bronze Age, Northern Germany, Kroll 1975) 


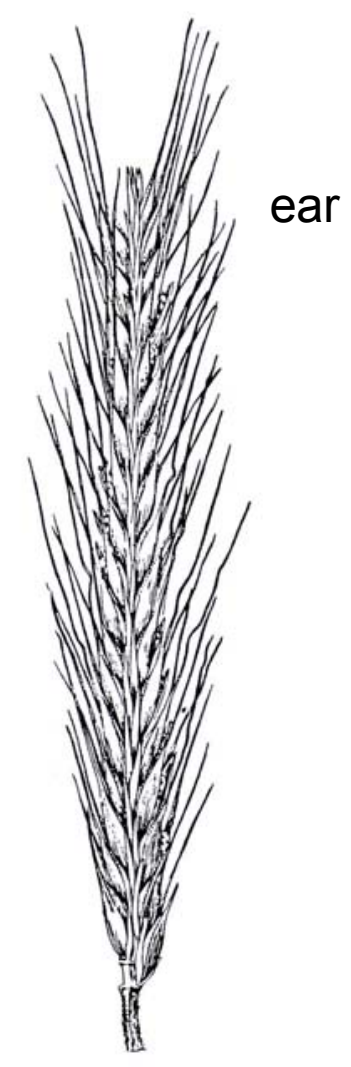

Zohary \& Hopf 2000

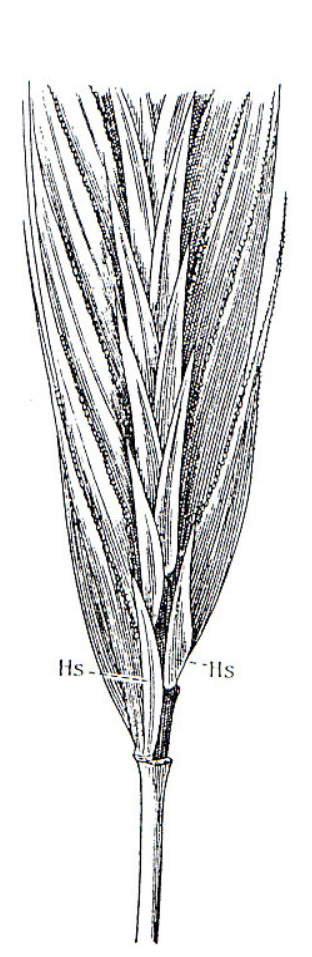

I

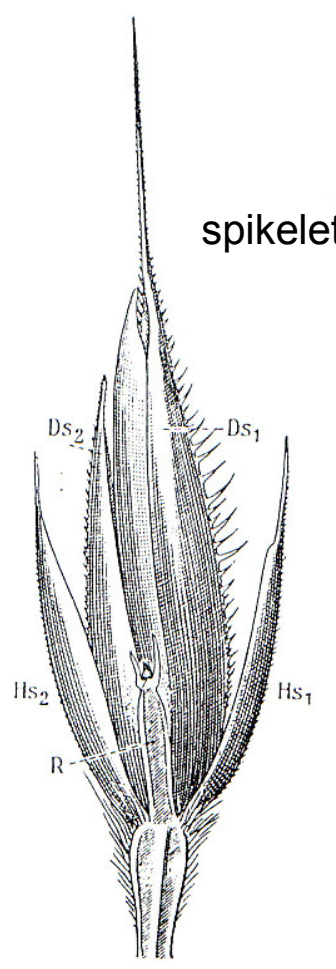

II

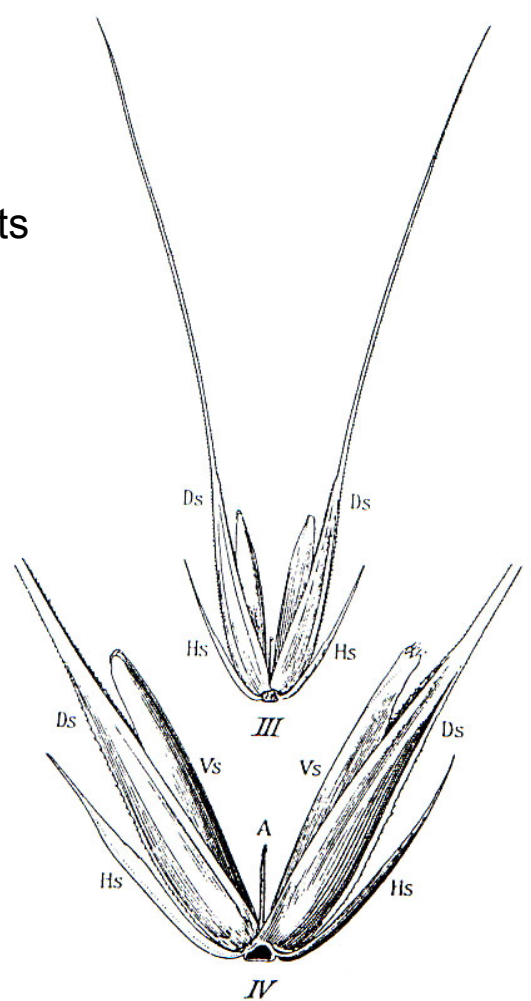

IV

Secale cereale (from Troll, 1954,1957). I lower part of the ear; Hs glumes (narrow). II apex of the ear with rudiment of the rachis $(\mathrm{R})$ und a fertile spikelet, Hs1, Hs2 glumes of the uppermost spikelet, Ds1, Ds2 the lemmas of the uppermost spikelet (only 1 grain developed in Ds1). III, IV spikelets in adaxial view: $A$ axis of the spikelet (rachilla); Hs glumes; Vs palaea's; Ds lemma's (both fertile). Rye spikelets have 2 fertile florets.

\section{Identification of rye-grains}

shape in dorsal view: oval, rather often with almost paerallel sides. Upper end truncate (to rounded). Lower (embryo) end strongly attenuated. Scutellum mostly very long.

Shape in lateral (side) view: Ventral face from rather convex to flat.

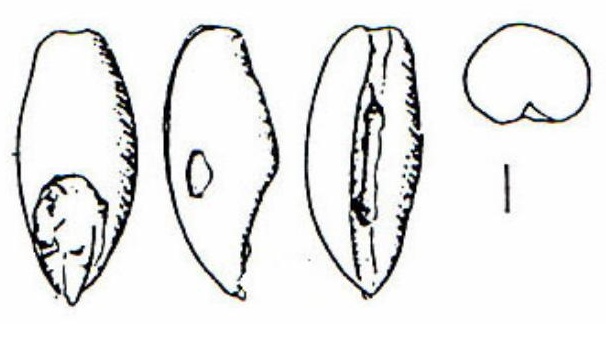
Back evenly arched to rather flat. Upper end suddently truncated.

Transverse section: mostly rounded. Hilum fold deep, reaching the apex of the grain.

Rye grains are usually easy to distinguish from wheat and barley grains by the truncated apex and the long scutellum.

Rye is a naked cereal, therefore the glumes don't leave a trace on the grain surface which is usually smooth and shiny.

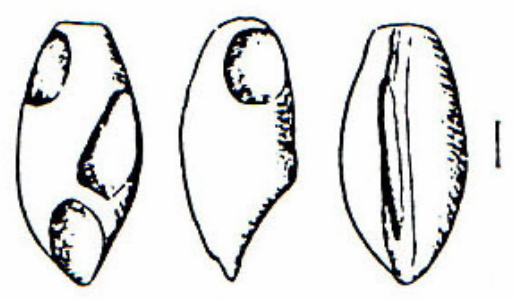


rye (Secale cereale): archaeological finds and identification criteria of the rachis remains)

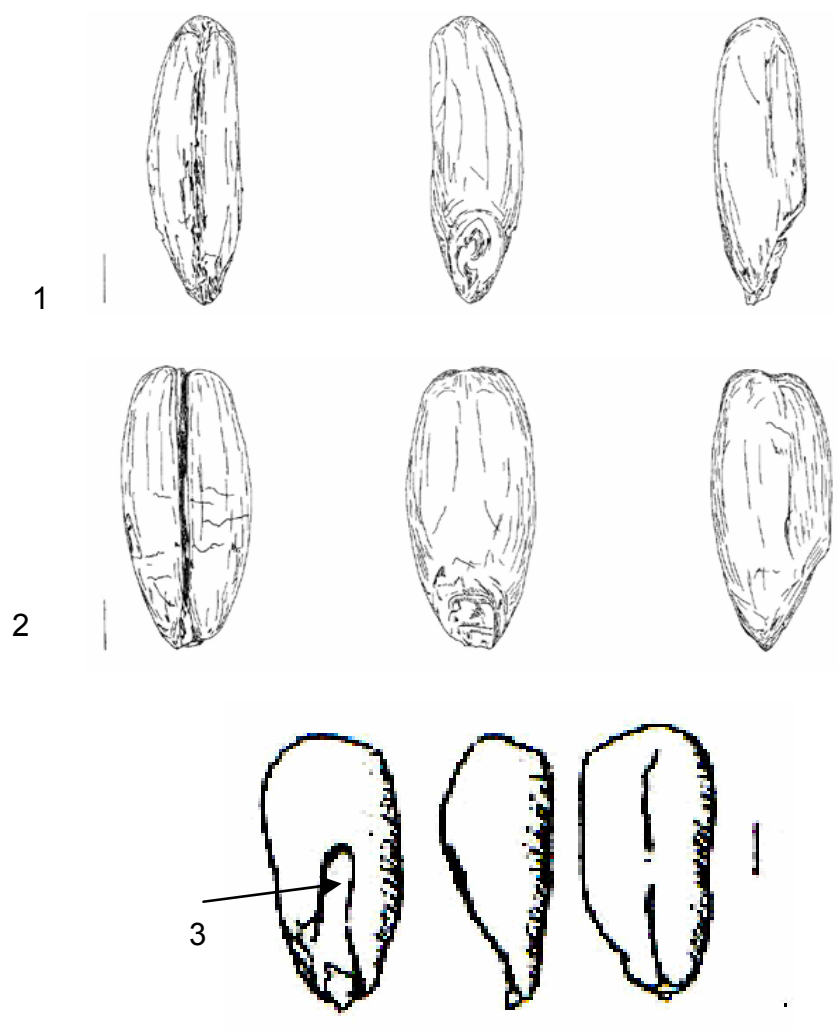

rye grains: 1,2 : from medieval Basel-Rosshof, Switzerland (Kühn 1996). 3: from Roman Augusta Raurica, Switzerland (Jacomet et al. 1988). 3: sprouted (arrow)

measurements and indices of rye grains from Roman Augusta Raurica (37 grains):

$\mathrm{L}: 5,1 \mathrm{~mm}(3,9-6,0 \mathrm{~mm})$

B: $2,4 \mathrm{~mm}(2,0-2,9 \mathrm{~mm})$

$\mathrm{H}: 2,2 \mathrm{~mm}(1,6-2,7 \mathrm{~mm})$

L/B: 2,14 (1,54-2,48)

L/H: 2,41 (1,62-3,56)

B/H: 1,13 (0,84-1,5)

Rachis remains of rye
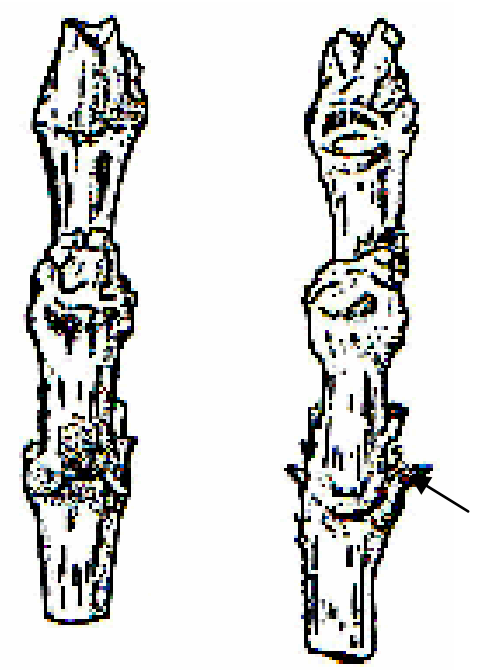

Dorestad NL (Van Zeist 1968)
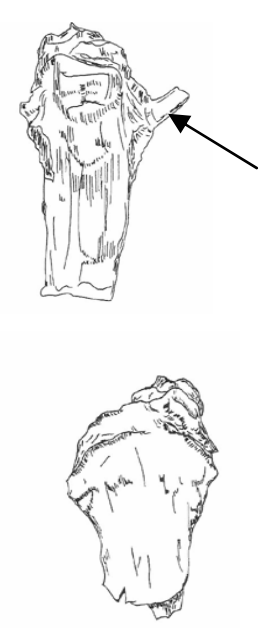

Basel-Rosshof, medieval (Kühn 1996)
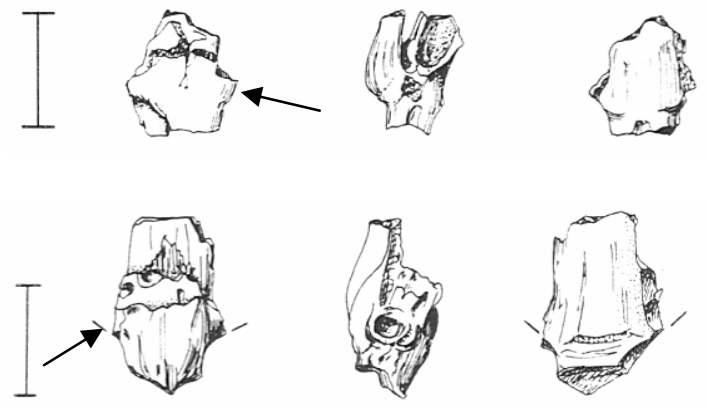

Basel, Reischacherhof, early Medieval (Jacomet \& Blöchliger 1994)

\section{$\longrightarrow$ glume bases}

Identification critieria: sides straight. The bases of the narrow glumes are visible at the side in the region of the node. 


\section{Oat (Avena species)}

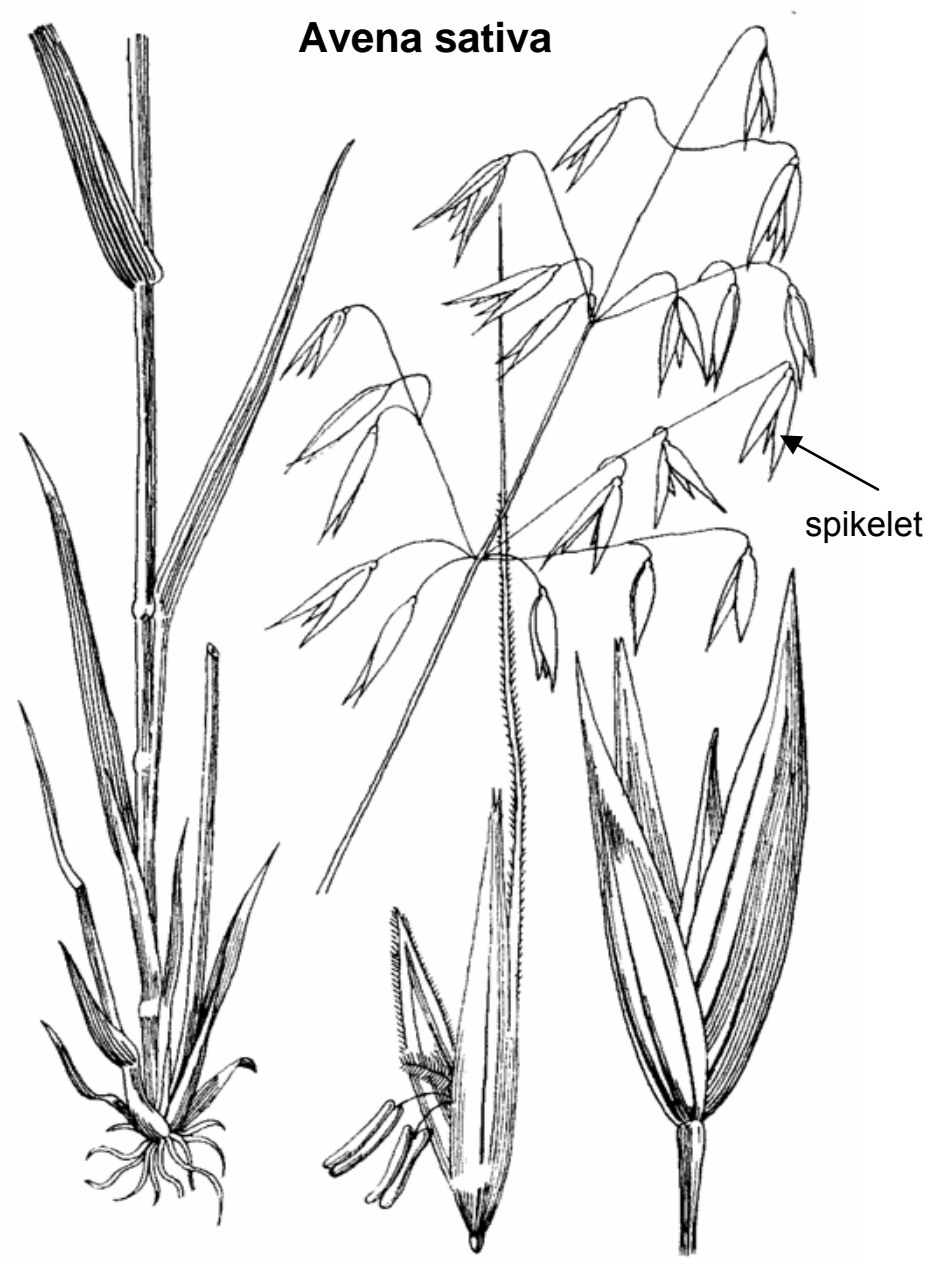

\section{spikelet}

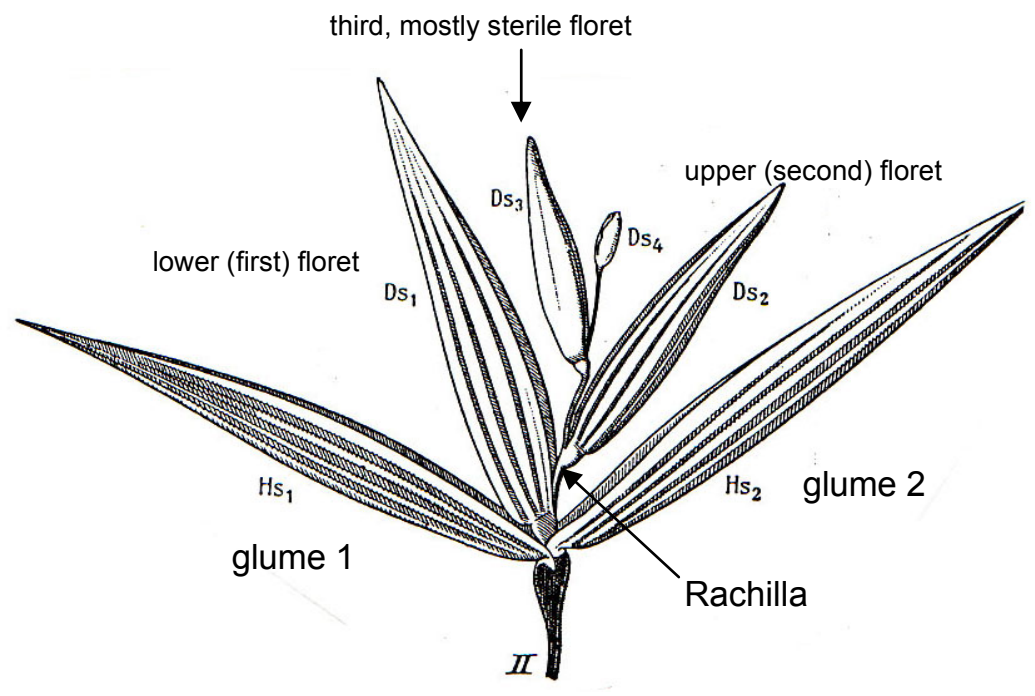

In contrast to wheat, barley and rye, oat has its spikelets in panicles.

In European archaeological contexts usually 4 different Avena-species may be present:

Avena sativa, the domestic oeat

Avena strigosa, weedy and cultivated

Avena fatua, a weed

Avena sterilis, a weed

They are not easy to distinguish in the archaeobotanical record. For the grains, this is rather impossible. If good preserved parts of the florets (esp. the lemma and parts of the rachilla) are present, it may be possible. the spikelets of $A$. sativa have usually two fertile florets (ev. 3)

Ds1 = lemma of the first floret (the first grain)

Ds 2 = lemma of the second floret (the second grain) from Troll 1954/1957 


\begin{tabular}{|c|c|c|c|}
\hline $\begin{array}{l}\text { Morphological } \\
\text { feature / plant part }\end{array}$ & Avena sativa & Avena strigosa & Avena fatua \\
\hline surface of the lemma & smooth, without hairs & $\begin{array}{l}\text { smooth, at the basis and the } \\
\text { rachilla occasionally a bit } \\
\text { hairy }\end{array}$ & $\begin{array}{l}\text { rough (grob gekörnelt), } \\
\text { densely hairy. Base of the } \\
\text { lemma and Rachilla with } \\
\text { dense and rough hairs }\end{array}$ \\
\hline awns on the lemma & $\begin{array}{l}\text { lemma of the first floret } \\
\text { occasionally with awn, lemma of } \\
\text { the second floret without awn. }\end{array}$ & all lemma's with awn & all lemma's with awn \\
\hline $\begin{array}{l}\text { Disarticulation scar } \\
\text { of the first floret }\end{array}$ & broad, close to the lemma-base & $\begin{array}{l}\text { narrow, often tapering } \\
\text { (attenuate), in some } \\
\text { distance of the lemma-base }\end{array}$ & $\begin{array}{l}\text { olique, horsehoe-shaped, } \\
\text { with bulge at the edge }\end{array}$ \\
\hline $\begin{array}{l}\text { Disarticulation scar } \\
\text { of the second floret }\end{array}$ & $\begin{array}{l}\text { narrow, close to the lemma- } \\
\text { base }\end{array}$ & see first floret & see first floret \\
\hline $\begin{array}{l}\text { Rachilla (spikelet } \\
\text { axe) }\end{array}$ & $\begin{array}{l}\text { That of the first floret broad and } \\
\text { short, that of the second floret } \\
\text { long and thin (fine) }\end{array}$ & $\begin{array}{l}\text { That of the first floret } \\
\text { narrow, at the upper end a } \\
\text { bit broadened and often } \\
\text { "gekniet". That of the } \\
\text { second floret is always very } \\
\text { thin. }\end{array}$ & thin \\
\hline Size of the grains & $\begin{array}{l}\text { First grains large, second grains } \\
\text { smaller (like A. strigosa). Max. } \\
\text { heigt in the center. }\end{array}$ & $\begin{array}{l}\text { Smaller than the first grains } \\
\text { of A. sativa, equal size than } \\
\text { the second grains of A. } \\
\text { sativa }\end{array}$ & $\begin{array}{l}\text { Similar to those of the } \\
\text { other species. Rather very } \\
\text { slender. Apex a bit } \\
\text { attenuated, max. height } \\
\text { below the center. }\end{array}$ \\
\hline
\end{tabular}


oat (Avena L.): flower base morphology: examples from a medieval site in France compared with modern specimen (from Ruas \& Pradat 2001)

FIG. 54

Lemmes actueiles d'Avena sativa vues en

face ventrales : a premier fleuron :

b deuxième fleuron.
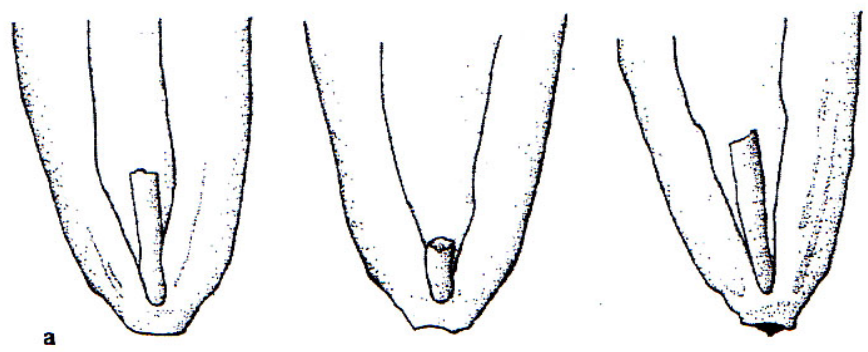

$0 \quad 1 \mathrm{~mm}$
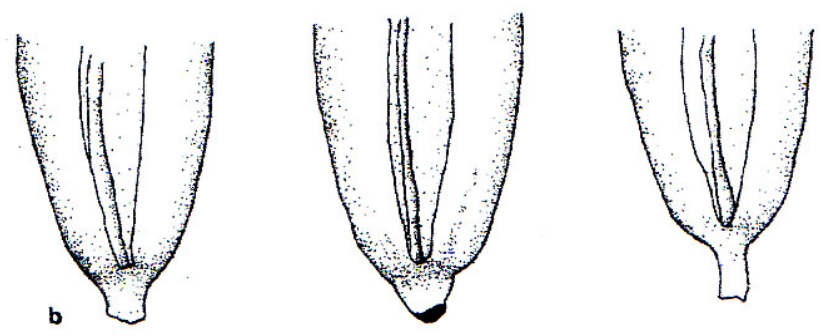

FIG. 55

Lemmes actuelles d'Avena strigosa (face ventrale).
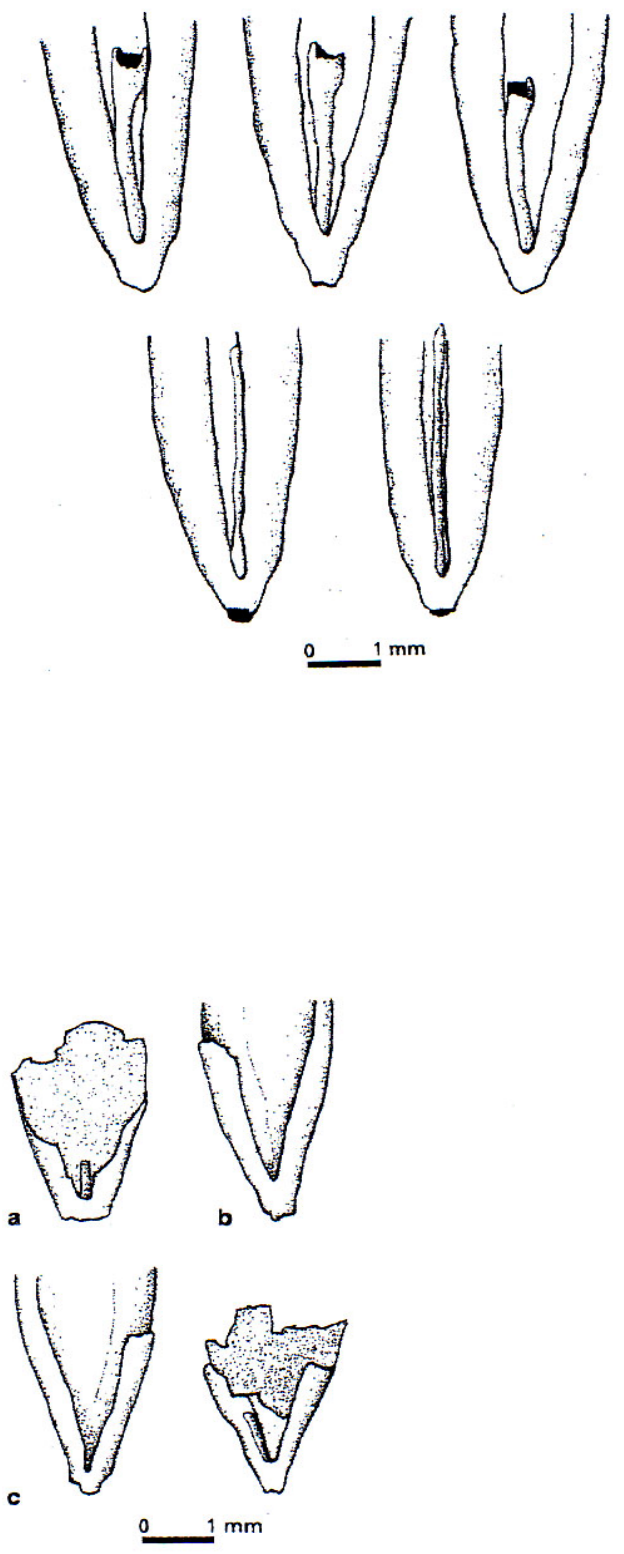

FIG. 57

Le Teilleul. Lemmes carbonisées d'avoines extraites de la fosse 2209 : a Avena sativa ; b Avena sativa/strigosa ; c Avena strigosa.

Lemmes carbonisées d'avoines : a Avena sativa, site de Gaudines (IXe-Xe s.) ; b Avena strigosa, site de Péran ( $x^{e} \mathrm{~s}$. .). 


\section{oat (Avena L.): Grain morphology and sizes}

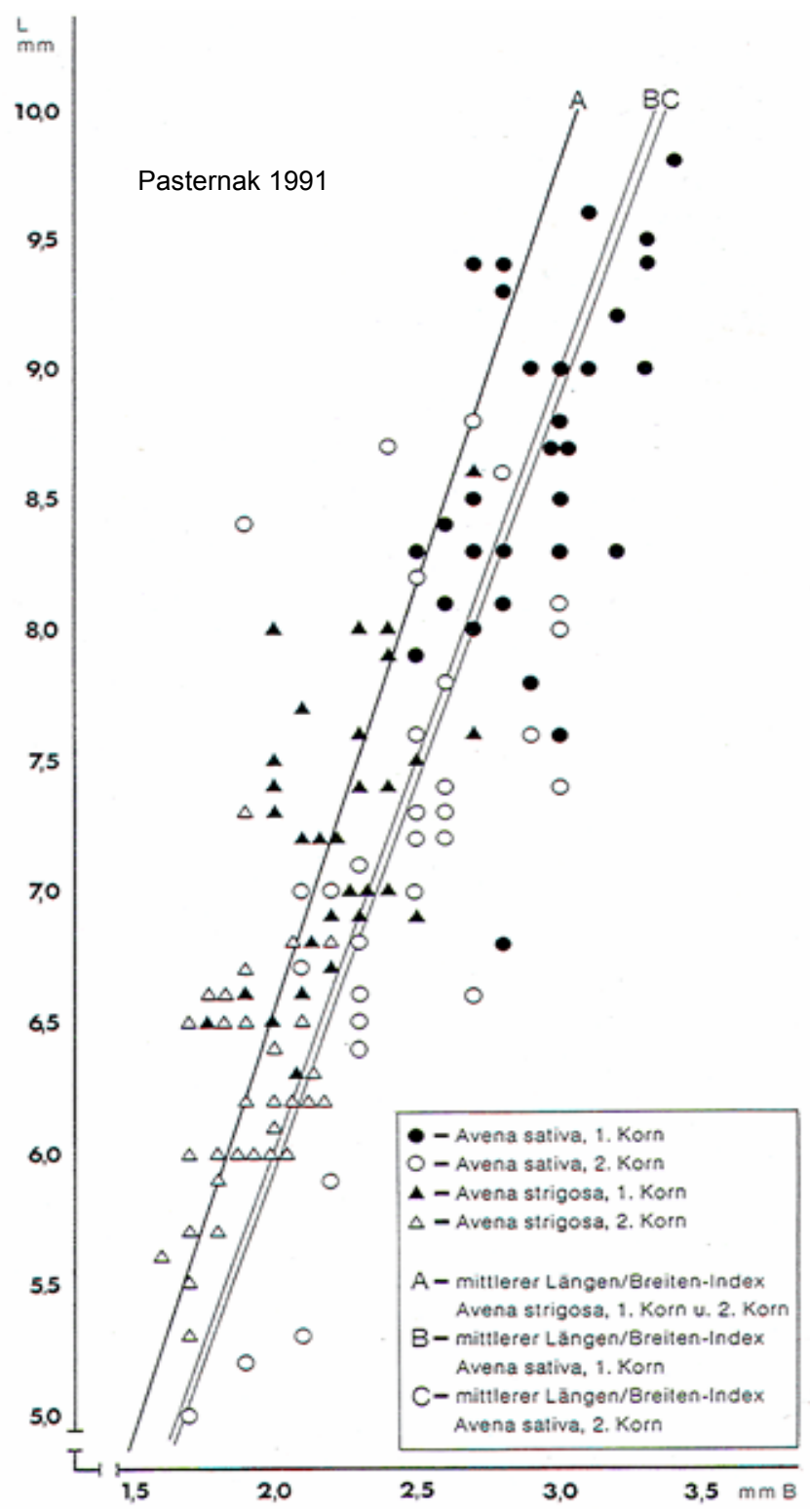

oat grains from Augst (Roman, Switzerland, Jacomet et al. 1988)
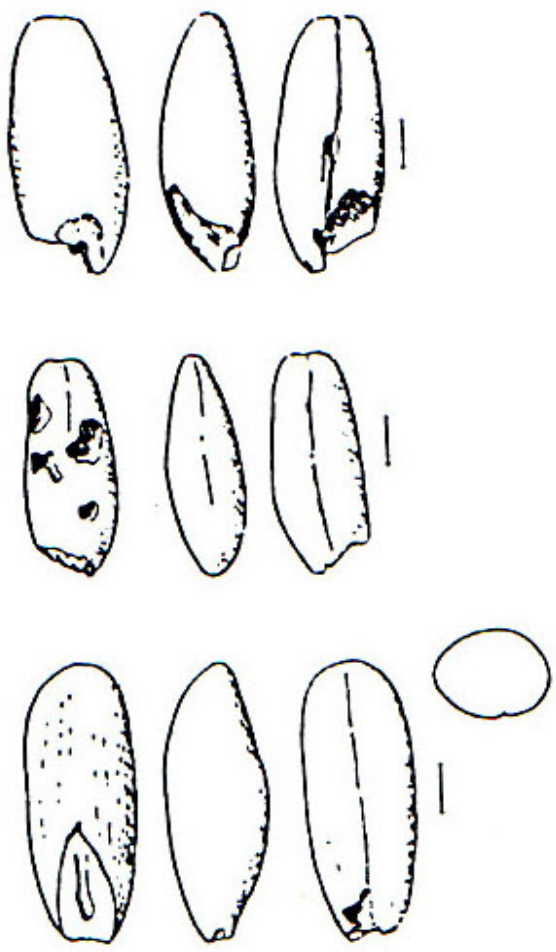

oat grains from Dorestad (Roman, Netherlands, Van Zeist 1968)
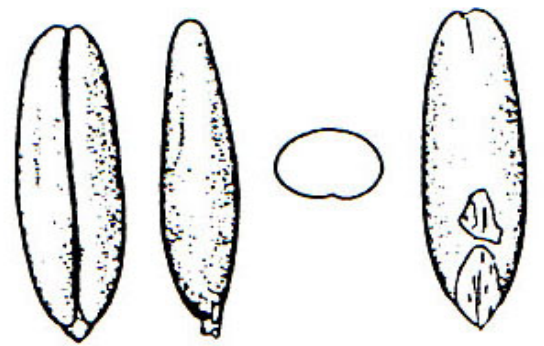

Dorsal view: Oat-grains are slender, the widest point is in the middle (esp. in A. sativa; in A. fatua also in the lower half). Sides maybe straight or slightly curved. Scutellum is rather long. Apex is rounded.

In lateral view the grains are rather flat, both sides are evenly arched and slightly convex. Apex rounded.

$\mathrm{Zu}$ den Messwerten: es wurden bespelzte Haferkörner gemessen. Die Körner wurden von Spelzbasis bis Kornende gemessen. Avena sativa hat im Mittel die größeren Körner, es wird allerdings deutlich, daß die ersten Körner von Avena strigosa und die zweiten Körner von Avena sativa in denselben Größenbereich fallen. Daraus folgt, daß eine Trennung der beiden Arten in entspelztem Zustand mit ausschließlich metrischen Methoden nicht möglich ist. Zwar hat Avena strigosa geringfügig schmalere und deutlich kleinere Körner, die große Streuung der Maße von Avena sativa verhindert jedoch eine Trennung der beiden Arten.

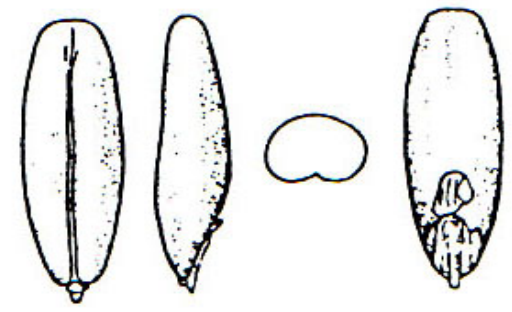


In the millets, the spikelets contain 1 floret. The inflorescences are panicles (in Setaria italica with very short branches!)

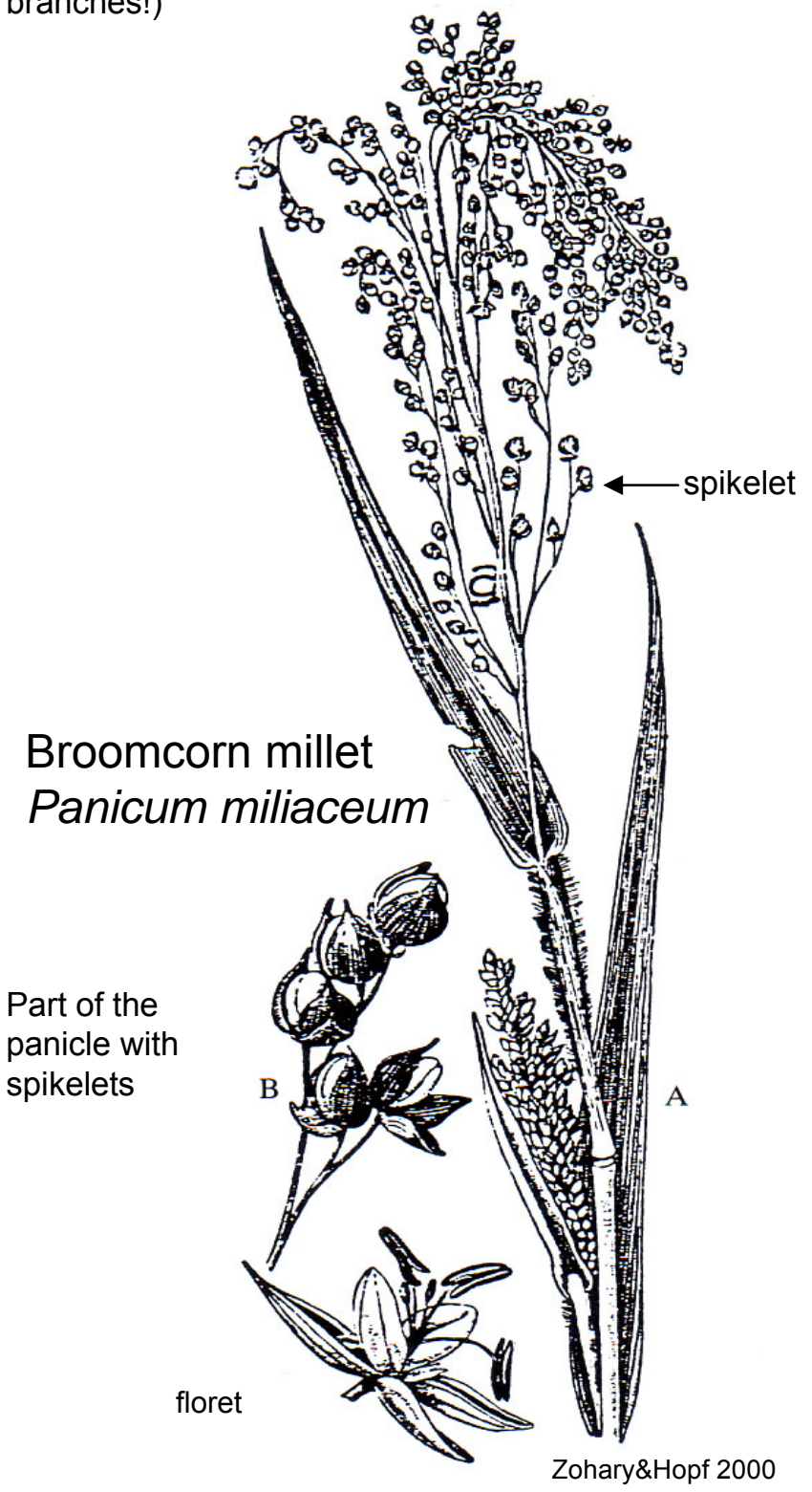

\section{Italian millet Setaria italica}
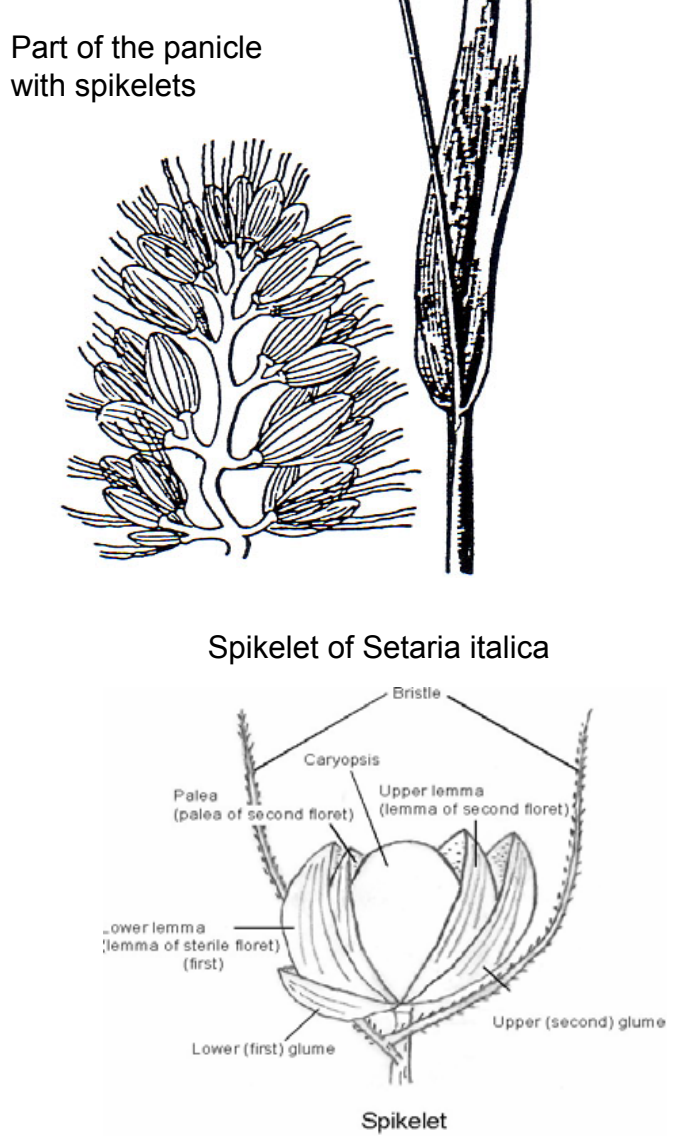

Nasu et al., in press (Vegetation History and Archaeobotany)

A spikelet in the millets consists of 1 sterile and 1 fertile floret. The lemma of sterile floret (lower lemma) ist still visible, the palea of the first floret is atrophied to very small and scarious organ and sometimes lost. The lemma and palea of the second floret are well developed and enclose the grain cloesely. 
Broomcorn millet: Panicum miliaceum L., Italian millet: Setaria italica (L.) P.B.

In the following literature characteristics of the domestic millet species can be found: NETOLITZKY 1914, KROLL 1983, KÖRBER-GROHNE 1967, KNÖRZER 1971 und WASYLIKOWA 1978 (see also Nasu et al., in press). The most important identification criterie are:

\section{- The surface structure of the lemma and palea:}

Panicum miliaceum: surface smooth, with some longitudinal stripes. Cells longish-rectangular.

Setaria italica: surface with papillae.

- The shape and size of the grains: KROLL 1983

P. miliaceum: oval; in carbonised state 1.3-2.2 mm long;.

S. italica: roundish; in carbonised state 1.1-1.7 mm long

- The shape of the scutellum (embryo-cavity) in naked grains:

Panicum miliaceum: very broad scutelleum with divergent edges versus the base. Reaches in maximum the half of the grain length. (In Echinochloa = Panicum crus-galli: scutellum a bit narrower than in P. miliaceum and reaching 2/3 of the grain length. Edges plus minus parallely).

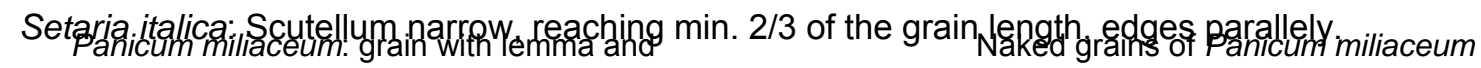
palea: Bronze Age, Zürich-Mozartstrasse,

Switzerland (Jacomet et al. 1989)
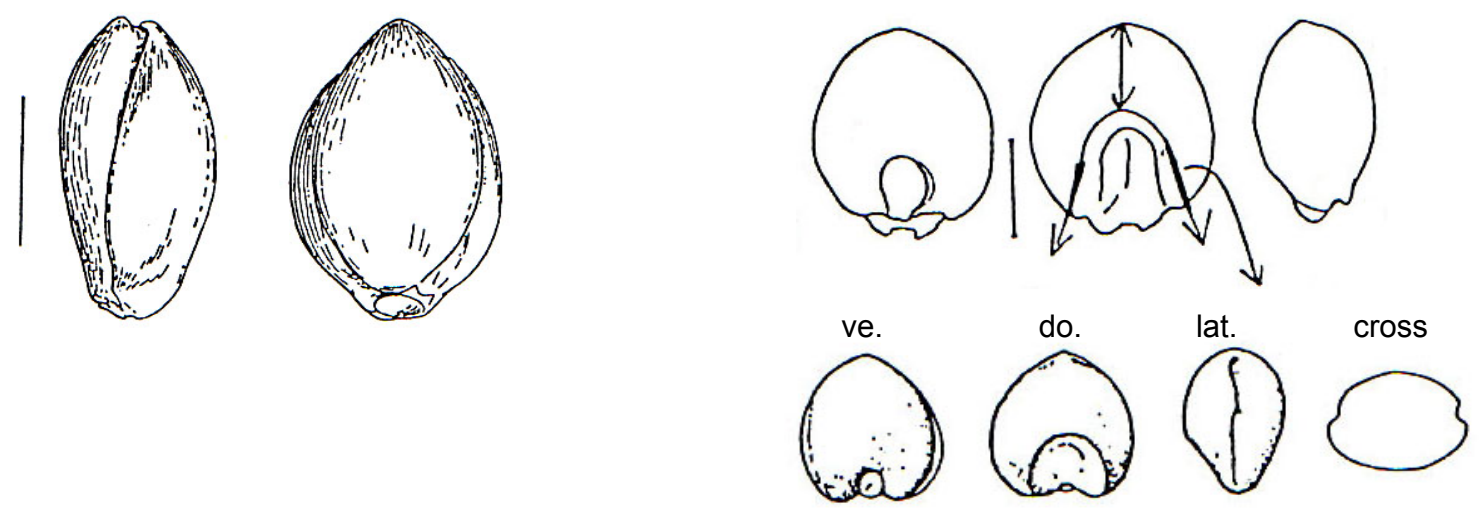

Naked grains of Setaria italica ( from several sites)
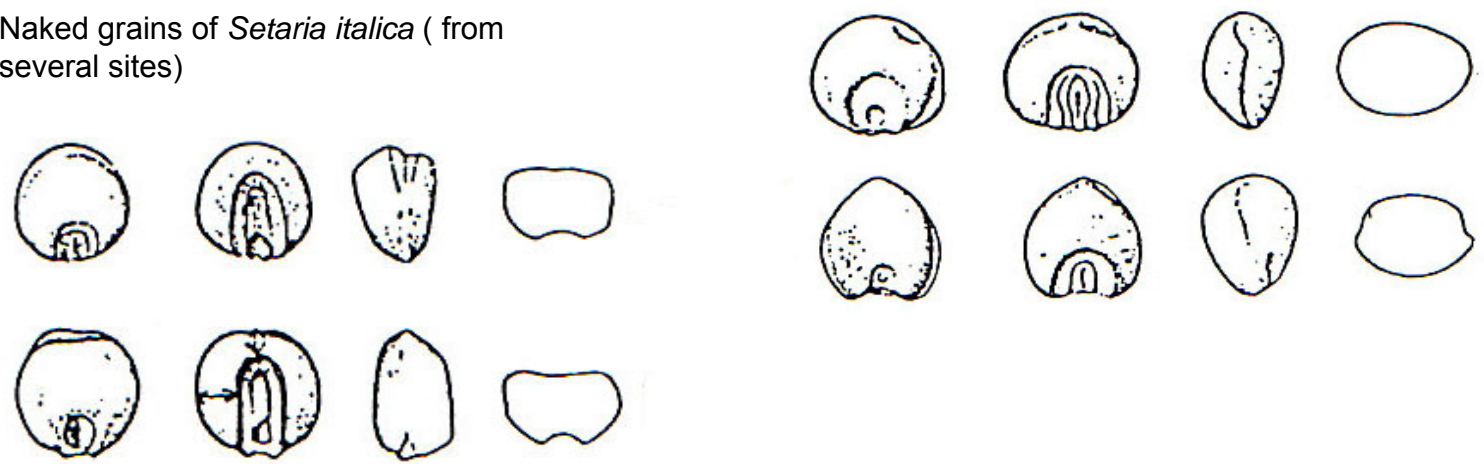

do.

lat.

cross
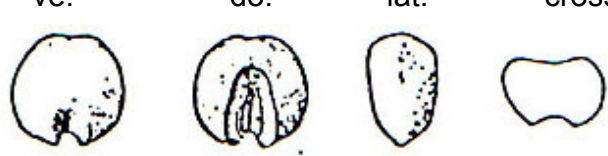

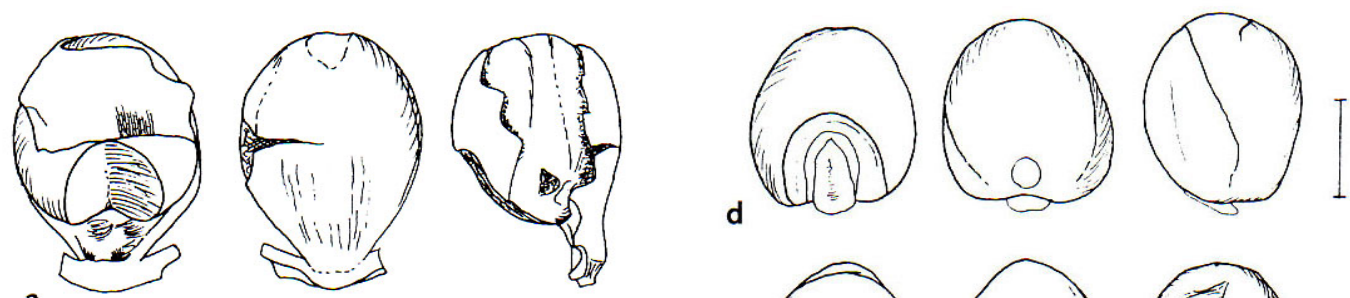

a
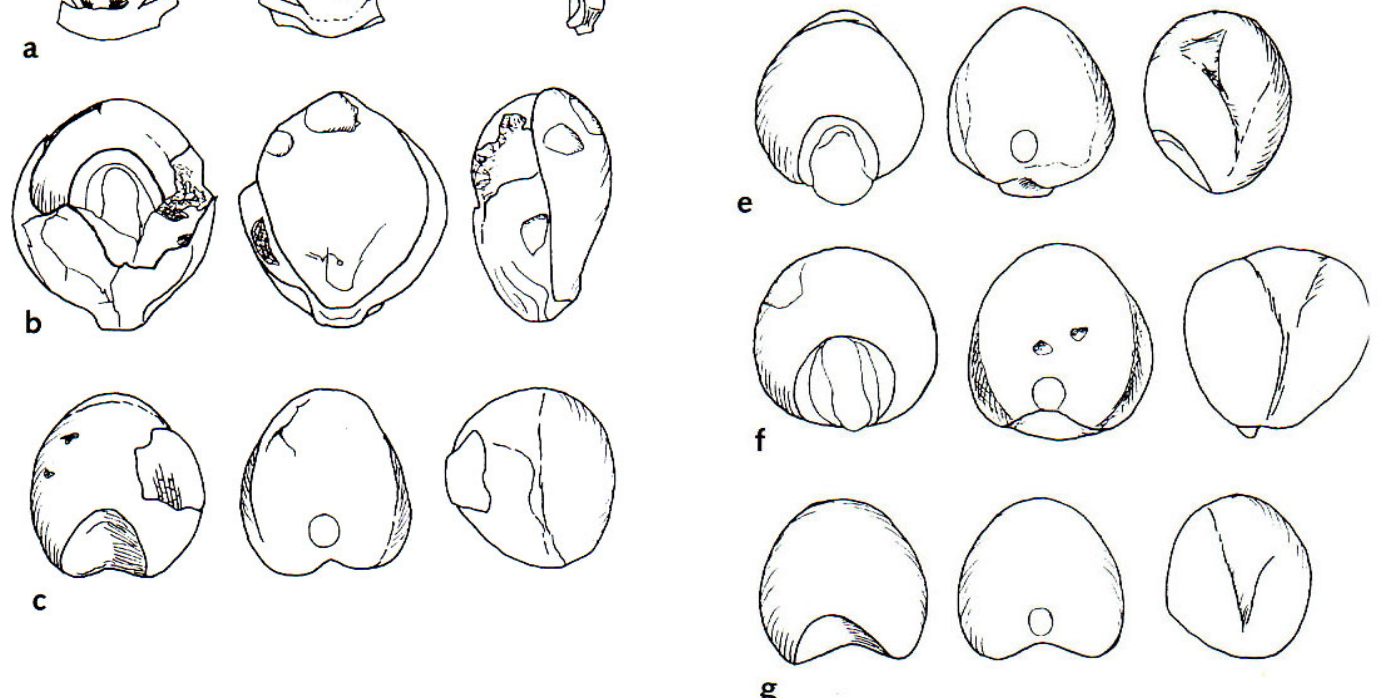

g

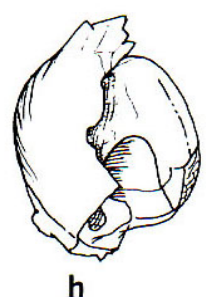

A-h: Rispenhirse (Panicum miliaceum), a-g: Körner von ventral, dorsal und lateral; a,b,c,h: Körner mit Spelzenresten (Kohler-Schneider 2001). 
Literaturliste I Bibliography: Cereal identification (and some additional literature)

Bogaard, A. (2004) Neolithic Farming in Central Europe. An archaeobotanical study of crop husbandry practices. London.

Bouby, L. (2001) L'orge à deux range (Hordeum distichum) dans l'agriculture Gallo-Romaine: données archéobotaniques. Revue d'Archéométrie 25, 35-44.

Brombacher, C. und Jacomet, S. (2003) Ackerbau, Sammelwirtschaft und Umwelt. In: Zwahlen, H. (Hrsg.) Die jungneolithische Siedlung PortStüdeli. Ufersiedlungen am Bielersee 7, Bern, 66-86.

Charles, M. P. (1984) Introductory remarks on the cereals. Bulletin on Sumerian Agriculture 1, 17-31.

Dalnoki, O. und Jacomet, S. (2002) Some aspects of Late Iron Age agriculture based on the first results of an archaeobotanical investigation at Corvin tér, Budapest, Hungary. Vegetation History and Archaeobotany 11/1-2, 9-15.

Dickson, C. (1989) The Roman army diet in Britain and Germany. In: Körber-Grohne, U. und Küster, H. (Hrsg.) Archäobotanik. Symposium der Universität Hohenheim (Stuttgart) vom 11.-16-Juli 1988. Dissertationes Botanicae 133, Berlin / Stuttgart, 135-154.

Hajnalová, E. (1978) Funde von Triticum-Resten aus einer hallstattzeitlichen Getreidespeichergrube in Bratislava-Devin/CSSR. Berichte der Deutschen Botanischen Gesellschaft 91, 85-96.

Helbaek, H. (1952a) Early Crops in Southern England. Proceedings of the Prehistoric Society 18/2, 194-233.

Helbaek, H. (1952b) Spelt (Triticum spelta L.) in Bronze Age Denmark. Acta Archaeologica 23, 97-107.

Hervey-Murray, C. G. (1980) The Identification of Cereal Varieties. Cambridge.

Hillman, G. C. (1984a) Interpretation of archaeological plant remains: the application of ethnographic models from Turkey. In: van Zeist, W. A. und Casparie, W. A. (Hrsg.) Plants and Ancient Man. Rotterdam, 1-41.

Hillman, G. C. (1984b) Traditional Husbandry and Processing of Archaic Cereals in Recent Times:The Operations, Products and Equipment which might feature in Sumerian Texts. Part I: The Glume Wheats. Bulletin on Sumerian Agriculture I, 114-151.

Hillman, G. C. (1985) Traditional Husbandry and Processing of Archaic Cereals in Recent Times: The Operations, Products and Equipment that might Feature in Sumerian Texts. Part II: The Free-Treshing Cereals. Bulletin on Sumerian Agriculture 2, 1-31.

Hillman, G. C. (2001) Archaeology, Percival, and the problems of identifying wheat remains. The Linnean (Special Issue) 3, 27-36.

Hillman, G. C., Mason, S., de Moulins, D. und Nesbitt, M. (1996) Identification of archaeological remains of wheat: the 1992 London workshop. Circaea 12/2, 195-210.

Hopf, M. (1955) Formveränderungen von Getreidekörnern beim Verkohlen. Berichte der Deutschen Botanischen Gesellschaft 68/4, $191-193$.

Hopf, M. (1963) Die Untersuchung von Getreideresten und anderen Feldfrüchten aus Altkalkar, Kr. Kleve, und Xanthen, Kr. Moers. Bonner Jahrbücher 163, 416-423.

Hopf, M. (1968) Früchte und Samen. In: Zürn, H. (Hrsg.) Das jungsteinzeitliche Dorf Ehrenstein (Kreis Ulm). Veröffentlichungen des Staatlichen Amtes für Denkmalpflege Stuttgart, Reihe A 10/II, Stuttgart, 7-77.

Hopf, M. (1975) Beobachtungen und Überlegungen bei der Bestimmung von verkohlten Hordeum-Früchten. Folia Quaternaria 46, 83-92.

Jacomet, S. (1987) Prähistorische Getreidefunde. Eine Anleitung zur Bestimmung prähistorischer Gersten- und Weizenfunde. Basel.

Jacomet, S. und Blöchliger, C. M. (1994) Verkohlte Pflanzenreste aus einem frühmittelalterlichen Grubenhaus (7./8. Jh. AD) auf dem Basler Münsterhügel Grabung Münsterplatz 16, Reischacherhof, 1977/3. Jahresbericht der archäologischen Bodenforschung Basel-Stadt, 106-143.

Jacomet, S., Brombacher, C. und Dick, M. (1989) Archäobotanik am Zürichsee. Ackerbau, Sammelwirtschaft und Umwelt von neolithischen und bronzezeitlichen Seeufersiedlungen im Raum Zürich. Ergebnisse von Untersuchungen pflanzlicher Makroreste der Jahre 1979-1988. Zürcher Denkmalpflege, Monographien 7. Zürich.

Jacomet, S. und Dick, M. (1986) Verkohlte Pflanzenreste aus einem römischen Grabmonument beim Augster Osttor (1966). Jahresberichte aus Augst und Kaiseraugst 6, 7-53.

Jacomet, S., Felice, N. und Füzesi, B. (1988a) Verkohlte Samen und Früchte aus der hochmittelalterlichen Grottenburg Riedfluh bei Eptingen, Kanton Baselland (Nordwest-Schweiz): Ein Beitrag zum Speisezettel des Adels im Hochmittelalter. In: Degen, P., Albrecht, H., Jacomet, S., Kaufmann, B. und Tauber, J. (Hrsg.) Die Grottenburg Riedfluh Eptingen BL. Bericht über die Ausgrabungen 1981-1983. Schweizer Beiträge zur Kulturgeschichte und Archäologie des Mittelalters (SBKAM) 15, 169-243.

Jacomet, S., Wagner, C., Felice, N., Füzesi, B. und Albrecht, H. (1988b) Verkohlte pflanzliche Makroreste aus Grabungen in Augst und Kaiseraugst. Kultur- und Wildpflanzenfunde als Informationsquellen über die Römerzeit. Jahresberichte aus Augst und Kaiseraugst 9, 271-310.

Jacomet, S. und Schlichtherle, H. (1984) Der kleine Pfahlbauweizen Oswald Heer's - Neue Untersuchungen zur Morphologie neolithischer Nacktweizen-Ähren. In: van Zeist, W. A. und Casparie, W. A. (Hrsg.) Plants and Ancient Man. Proceedings of the sixth symposium of the international work group for palaeoethnobotany 1983 in Groningen. Rotterdam, 153-176.

Jäger, K.-D. (1966) Die pflanzlichen Grossreste aus der Burgwallgrabung Tornow, Kr.Calw. In: Herrmann, J. (Hrsg.) Tornow und Vorberg: Ein Beitrag zur Frühgeschichte der Lausitz. Schriften der Sektion für Vor- und Frühgeschichte 21, 164-189.

Jones, G. E. M., Valamoti, S. und Charles, M. (2000) Early crop diversity: a "new" glume wheat from northern Greece. Vegetation History and Archaeobotany 9/3, 133-146.

Jörgensen, G. (1975) Triticum aestivum s. I. from the Neolithic Site of Weier in Switzerland. Folia Quaternaria 46, 7-21.

Kaussmann, B. und Schiewer, U. (1989) Funktionelle Morphologie und Anatomie der Pflanzen. Jena.

Kislev, M. E. (1979) Triticum pavicoccum sp. Nov., The oldest naked wheat. Israel Journal of Botany 28, 95-107.

Kislev, M. E. (1984) Botanical evidence for ancient naked wheats in the Near East. In: Van Zeist, W. A. und Casparie, W. A. (Hrsg.) Plants and Ancient Man. Studies in Palaeoethnobotany. Proceedings of the 6th Symposium of the International Work Group for Palaeoethnobotany, Groningen, 30st May-3rd June 1983. Rotterdam \& Boston, 141-152.

Knörzer, K.-H. (1967) Subfossile Pflanzenreste von bandkeramischen Fundstellen im Rheinland. In: Knörzer, K.-H.: Untersuchungen subfossiler pflanzlicher Grossreste im Rheinland. Archäo-Physika 2, 3-29. Knörzer, K.-H. (1970) Römerzeitliche Pflanzenfunde aus Neuss. Novaesium IV, Limesforschungen 10. Berlin.

Knörzer, K.-H. (1971) Eisenzeitliche Pflanzenfunde im Rheinland. Bonner Jahrbücher 171, 40-58.

Kohler-Schneider, M. (2001) Verkohlte Kultur- und Wildpflanzenreste aus Stillfried an der March als Spiegel spätbronzezeitlicher Landwirtschaft im Weinviertel, Niederösterreich (Habilitationsschrift). Mitteilungen der prähistorischen Kommission. Wien. 


\section{Literaturliste / Bibliography: Cereal identification (and some additional literature)}

Körber-Grohne, U. (1967) Geobotanische Untersuchungen auf der Feddersen Wierde. Text- und Tafelband. Wiesbaden.

Körber-Grohne, U. und Piening, U. (1980) Microstructure of the surfaces of the carbonized and non-carbonized grains of cereals as observed in scanning electron and light microscopes as an additional aid in determining prehistoric findings. Flora 170, 189228.

Körber-Grohne, U. und Piening, U. (1983) Die Pflanzenreste aus dem Ostkastell von Welzheim mit besonderer Berücksichtigung der Graslandpflanzen. In: Körber-Grohne, U., Kokabi, M., Piening, U. und Plank, D. (Hrsg.) Flora und Fauna im Ostkastell von Welzheim. Forschungen und Berichte zur Vor- und Frühgeschichte in Baden-Württemberg 14, Stuttgart, 17-88.

Kreuz, A. und Boenke, N. (2003) Zweikörniges Einkorn zur Zeit der Bandkeramik: Archäologisches Indiz oder Laune der Natur? In: Eckert, J., Eisenhauer, U. und Zimmermann, A. (Hrsg.) Archäologische Perspektiven. Analysen und Interpretationen im Wandel. Festschrift für Jens Lüning zum 65. Geburtstag. Internationale Archäologie: Studia Honoraria 20, Rahden/Westf., 233241.

Kroll, H. (1975) Pflanzliche Reste aus subfossilen Ackerböden der bronze- bis wikingerzeitlichen Siedlungen in Archsum auf Sylt (Schleswig-Holstein). Folia Quaternaria 46, 31-34.

Kroll, H. J. (1983) Kastanas. Ausgrabungen in einem Siedlungshügel der Bronze- und Eisenzeit Makedoniens 1975 - 1979. Prähistorische Archäologie in Südosteuropa 2.

Kühn, M. (1996) Spätmittelalterliche Getreidefunde aus einer Brandschicht des Basler Rosshof-Areales (15. Jahrhundert A.D.). Materialhefte zur Archäologie in Basel 11. Basel.

Ladizinsky, G. (1984) Key to the genus Avena. Plant Genetics Resources Newsletter 61, $37 \mathrm{ff}$.

Maier, U. (1996) Morphological studies of free-threshing wheat ears from a Neolithic site in southwest Germany, and the history of the naked wheats. Vegetation History and Archaeobotany 5, 39-55.

Mansfeld, R. (1950) Das morphologische System der Saatgerste, Hordeum vulgare L. s.l. Züchter 20, 9-24.

Moffett, L. (1991) The Archaeobotanical Evidence for Free-threshing Tatraploid Wheat in Britain. In: Palaeoethnobotany and Archaeology. International Work-Group for Palaeoethnobotany 8th Symposium Nitra-Nové Vozokany 1989. ACTA 7, $233-244$.

Nasu, H., Momohara, A., Yasuda, Y. und He, J. (in press) The occurrence and identification of foxtail millet [Setaria italica (L.) P. Beauv.] grains from the Chengtoushan site (ca. 5800 cal. B.P.) in central China, with reference to the domestication centre in Asia. Vegetation History and Archaeobotany.

Nesbitt, M. und Samuel, D. (1996) From staple crop to extinction? The archaeology and history of the hulled wheats. In: Padulosi, S., Hammer, K. und Heller, J. (Hrsg.) Hulled wheats. Promoting the conservation and use of underutilized and neglected crops 4. Proceedings of the First International Workshop on Hulled Wheats, 21-22 july 1995, Castelvecchio Pascoli, Tuscany, Italy. Rom, 41-100.

Netolitzky, F. (1914) Die Hirse aus antiken Funden. Sitzungsb. der mathemat.-naturw. Klasse 23/1, 725-759.

Pasternak, R. (1991) Hafer aus dem mittelalterlichen Schleswig. Offa 48, 363-380.

Percival, J. (1974 (Reprint von 1921)) The Wheat Plant. London.

Petrucci-Bavaud, M. und Jacomet, S. (2002) Die archäobotanischen Makroreste aus den befestigungszeitlichen Schichten. In: Schwarz, P.-A. (Hrsg.) Kastelen 4. Die spätrömischen Befestigung auf Kastelen - Ein Beitrag zur Geschichte in Augusta Raurica im späteren 3. und frühen 4. Jahrhundert. Forschungen in Augst 24, Augst, 287-323.

Piening, U. (1981) Die verkohlten Kulturpflanzenreste aus den Proben der Cortaillod- und Horgener Kultur. In: Ammann, B., Bollinger, T., Jacomet, S., Liese-Kleiber, H. und Piening, U. (Hrsg.). Die neolithischen Ufersiedlungen von Twann 14, Bern, 6988.

Rothmaler, W. (1955) Zur Fruchtmorphologie der Weizen-Arten (Triticum L.). Feddes Repertorium 57/3, 14, $210-215$.

Ruas, M. P. und Pradat, B. (2001) Les semences découvertes: plantes attestées et origine des déchets. In: Catteddu, I. (Hrsg.) Les habitats carolingiens de Montours et La Chapelle-Saint-Aubert (Ille-et-Vilaine). Documents d'archéologie française 89, Paris, $65-79+219-221$.

Salamini, F., Ozkan, H., Brandolini, A., Schafer-Pregl, R. und Martin, W. (2002) Genetics and geography of wild cereal domestication in the Near East. Nature Reviews Genetics 3/6, 429-441.

Schiemann, E. (1948) Weizen, Roggen, Gerste. Systematik, Geschichte und Verwendung. Jena.

Schlichtherle, H. (1985) Samen und Früchte: Konzentrationsdiagramme pflanzlicher Grossreste aus einer neolithischen Seeuferstratigraphie. Quantitative Untersuchungen an einem Profilsockel in Yverdon, Avenue des Sports. Freiburg i. Br.

Schubert, R. und Wagner, G. (1988) Botanisches Wörterbuch. UTB 1476. Stuttgart.

Troll, W. (1954, 1957) Praktische Einführung in die Pflanzenmorphologie, 2 Bände. Jena.

van Zeist, W. A. (1968) Prehistoric and early historic food plants in the Netherlands. Palaeohistoria 14, 42-173.

van Zeist, W. A. (1984) List of names of wild and cultivated cereals. Bulletin on Sumerian Agriculture 1, 8-16.

Villaret - von Rochow, M. (1967) Frucht- und Samenreste aus der neolithischen Station Seeberg, Burgäschisee-Süd. In: (Hrsg.) Seeberg Burgäschisee Süd, Teil 4: Chronologie und Umwelt. Acta Bernensia 2, Bern, 21-63.

Wasylikowa, K. (1978) Plant remains from early and late medieval time found on the Wawel hill in Cracow. Acta Palaeobotanica 19/2, 115-198.

Zeder, M. A., Emshviller, E., Smith, B. D. und Bradley, D. G. (2006) Documenting domestication: the intersection of genetics and archaeology. TRENDS in Genetics 22 /3 march 2006, 139-155.

Zeder, M. A. e. a. (2006 ) Documenting Domestication: New Genetic and Archaeological Paradigms. Berkeley.

Zibulski, P. (2001) Archäobotanische Untersuchungen der Makroreste (Samen, Früchte und Dreschreste). In: Gnepf Horisberger, U. und Hämmerle, S. (Hrsg.) Cham-Oberwil, Hof (Kanton Zug). Befunde und Funde aus der Glockenbecherkultur und der Bronzezeit. Antiqua 33, Basel, 150-166, 285-295, 333-339.

Zohary, D. und Hopf, M. (2000) Domestication of Plants in the Old World. The origin and spread of cultivated plants in West Asia, Europe and the Nile Valley. Oxford. 